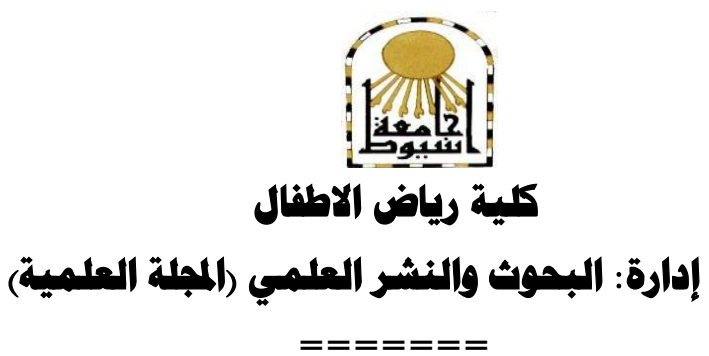

\title{
فاعلية برنامج قائم على استراتيجيات التعلم \\ النشط في تنمية بعض المفاهيم العلمية \\ وعمليات العلم لدى طفل الروضة

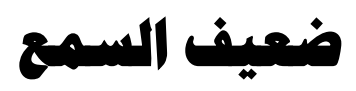

\author{
إعـــــاد \\ أ.م.د/ عبير صديق أمين \\ أستاذ مناهج الطقل المساعد \\ بكلية التربية للطفولة المبكرة - جامعة القاهرة
}

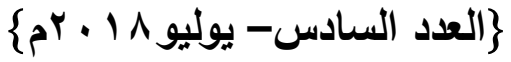




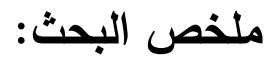

يهدف البحث إلى دراسة فاعلية برنامج أنشطة قائم على استراتيجيات التعلم النشط

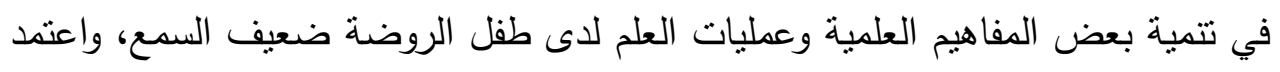

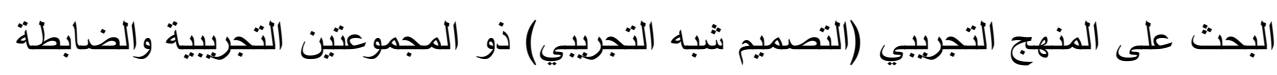

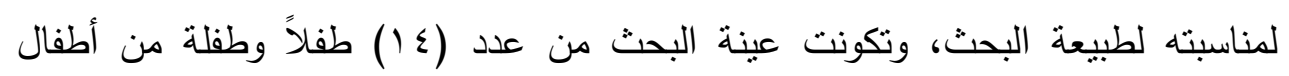
الروضة ضعاف السمع بمركز الصم و ضعاف السمع التابع لجمعية المبرات بمحافظة القاهرة، تم تقسيمها إلى مجموعتين متكافئتين احداهما تجريبية والأخرى ضابطة، واستخدم البحث مجموعة من الأدوات: مقياس ستانفورد - بينيه لقياس ذكاء الأطفال - الصورة

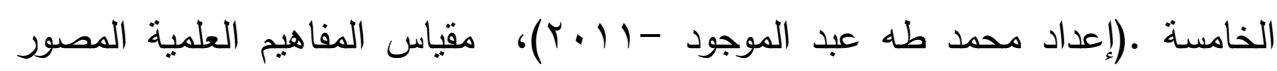

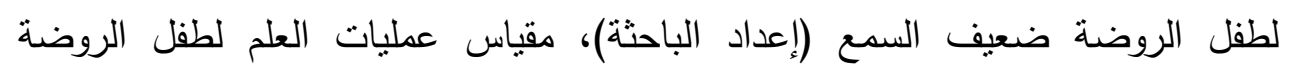

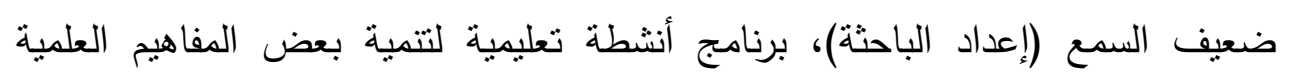

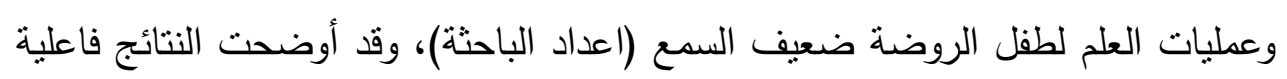
برنامج الأنشطة التعليمية باستخدام بعض استراتيجيات التعلم النشط (التعلم التعاوني -

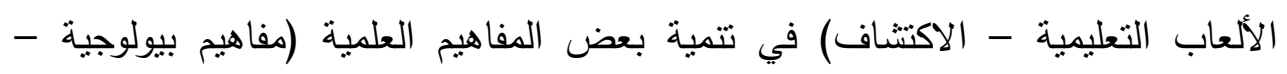

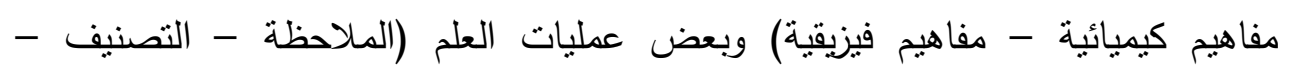
الاستتاج) لدى طفل الروضة ضعيف السمع. كلمات مفتاحية :

طفل الروضة - ضعيف السمع - المفاهيم العلمية - عمليات العلم استراتيجيات التعلم النشط . 


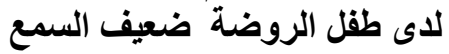

\section{The Effectiveness of a Program Based on Active Learning Strategie in the development of some scientific Concepts and Processes of Science for Hearing Impaired Kindergarten Children}

\section{Research Summary:}

The research aims to study the effectiveness of using some active learning strategies in the development of some scientific concepts and the science processes of the kindergarten child. The research was conducted on the experimental method (semiexperimental design) of the experimental and control groups for the nature of the research. A child and a child from the Kindergarten Children with Hearing Impairment at the Deaf and Hearing Impaired Center of the Al-Mabarat Association in Cairo Governorate were divided into two equal groups, one experimental and the other an officer : tanford - Binet Institute for the Measurement of Children's Intelligence - Fifth Image (Prepared by Mohamed Taha AbdelMoqood-2011), The Scientific Conceptual Measure of the Hearing Impaired Kindergarten Child, Some of the scientific concepts and the science processes of the preschool child are poorly audible. The results showed the effectiveness of the program of educational activities using some active learning strategies (cooperative learning, educational games, discovery) in the development of some scientific concepts (biological concepts, chemical concepts, Aziqih) and some science operations (note - Classification - Conclusion) of the kindergarten child hearing impaired .

Keywords :

Kindergarten Child - Hearing Impaired - Scientific Concepts Science Operations - Active Learning Strategies. 


\section{مقدمة:}

إن الأطفال ذوي الحاجات الخاصة لهم الحق في الحصول على الفرص التعليمية المتاحة لجميع الأطفال الآخرين، وهذا ما تتص عليه حقوق الطفل في الدساتير والتشريعات

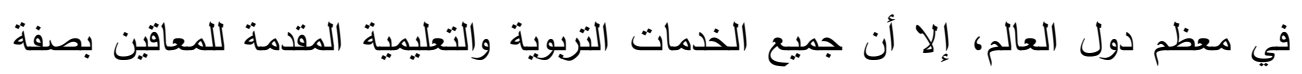
عامة، والمعاقين سمعياً بصفة خاصة ضئيلة للغاية مقارنة بما هو مقام للأسوياء

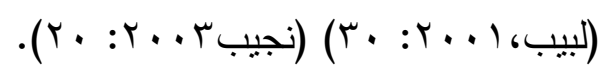

وفي إطار مقارنة أداء ضعاف السمع مع العاديين نجد أن كثير من علماء النفس

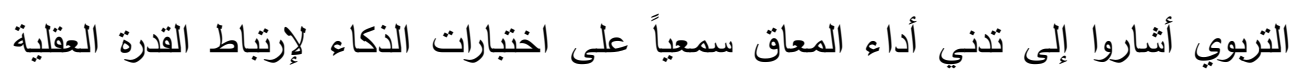
بالقدرة اللغوية، وذلك بسبب تشبع تلك الاختبارات بالناحية اللفظية، ويشير فيرث وآخرون (Furth,1973) بالرغم من الصعوبات التي يواجهها الصم في التعبير عن بعض المفاهيم وخاصة المفاهيم

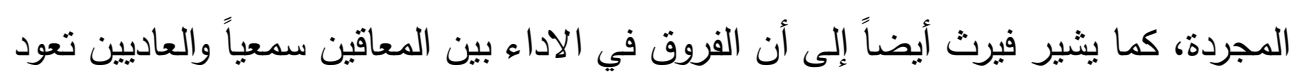

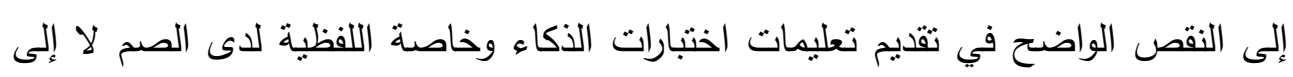
قدرات الصم العقلية.

وبالرغم من أن ضعاف السمع يكتسبون المفاهيم بنفس درجة التسلسل التقليدي لدى

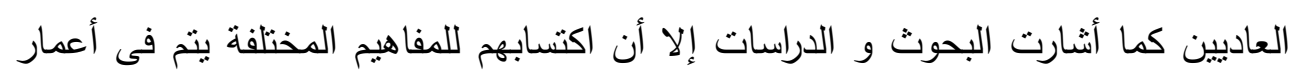

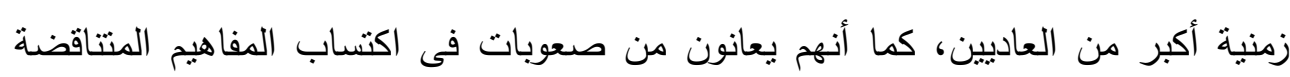

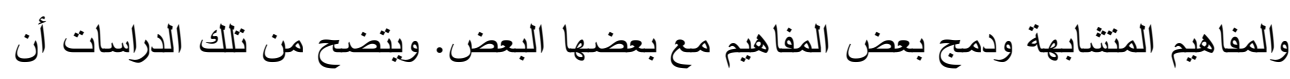

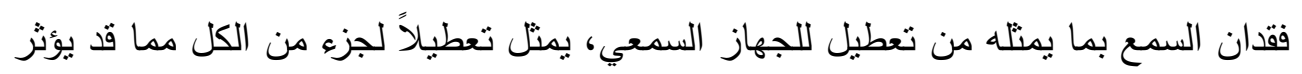

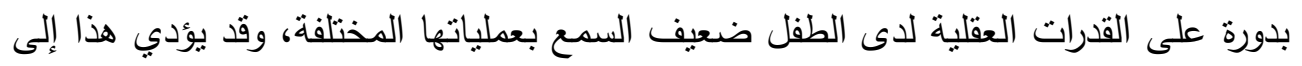

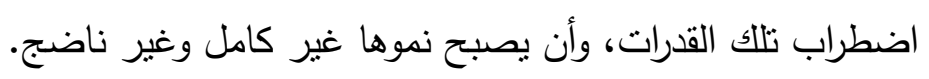

(Deafness and Hearing Impairment,2006) 
بينما أوضحت دراسة (عباس، ( . ب) في مقارنتها لذوي السمع العادي والمعاقين

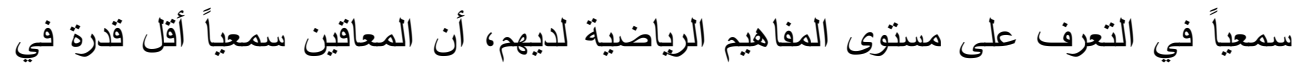

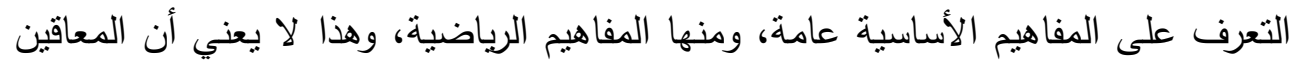

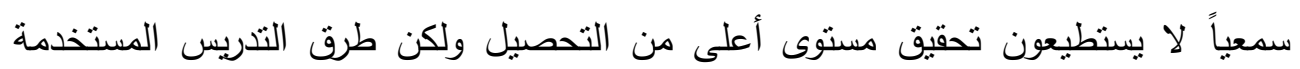

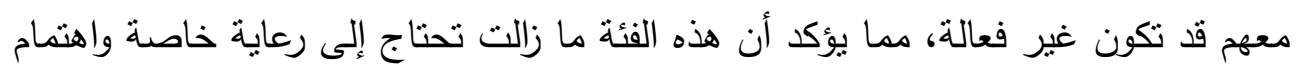
بأسلوب النعليم الملائم لاحتياجاتهم وطبيعة اعاقتهم.

وبالرغم من ذلك نلاحظ قلة البحوث والدراسات التي تهتم بتتمية المفاهيم المختلفة

لدى طفل الروضة ضعيف السمع، وتركيزها على مجال المفاهيم والقدرات والمهارات اللغوية

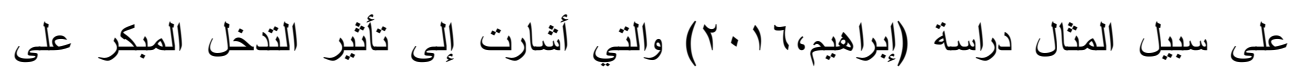

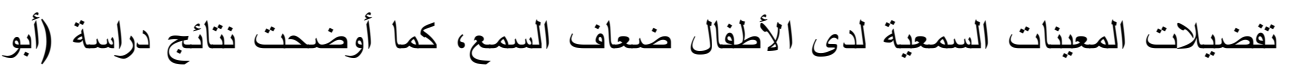

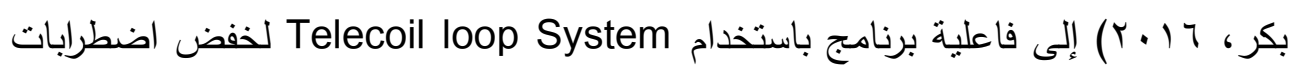

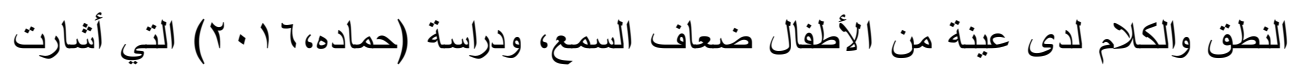

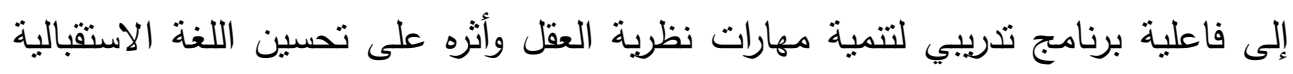

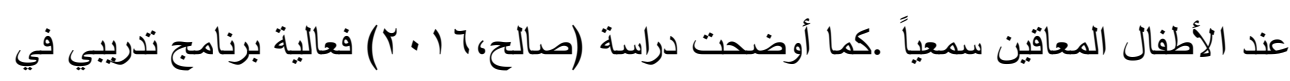

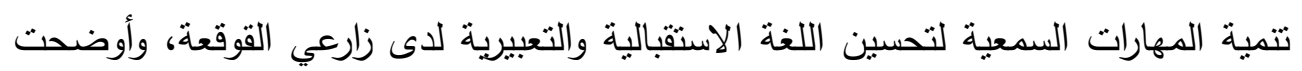

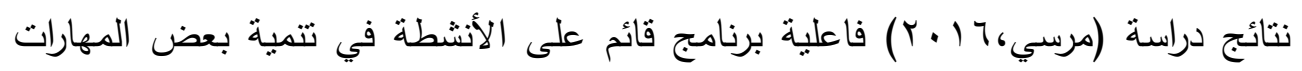
اللغوية لاى الأطفال ضعاف السمع.

ومن جانب آخر نجد أن الطفل العادي يواجه بعض الصعوبات فى اكتساب

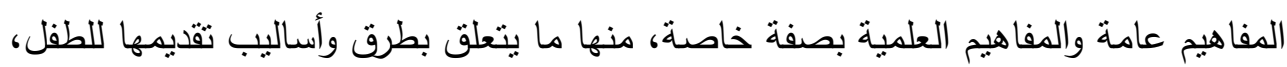

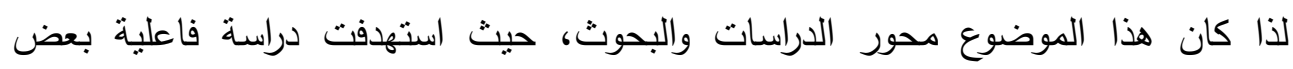
الاستراتيجيات التعليمية فى تتمبية بعض المفاهيم والمهارات العلمية لدى طفل الروضة منها

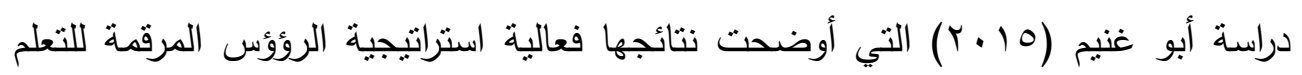

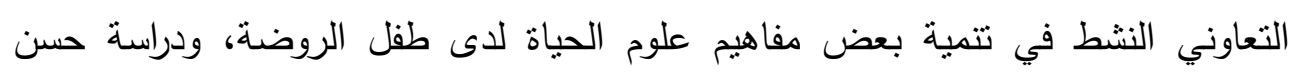

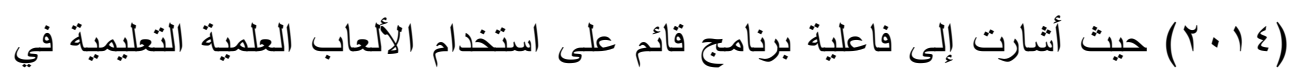
ضوء المعايير القومية في اكتساب المفاهيم العلمية وتتمية بعض مهارات عمليات العلم 
الأساسية والتفكير الابتكاري لدى أطفال الروضة ودراسة (Ni Chang, 2012) التي أثارت إلى فاعلية الأنشطة الفنية ومنها الرسم في تتمية المفاهيم العلمية لدى الطفل.

كما اهتمت البحوث والدراسات بتوظيف استراتيجيات التعلم النشط في تتمية

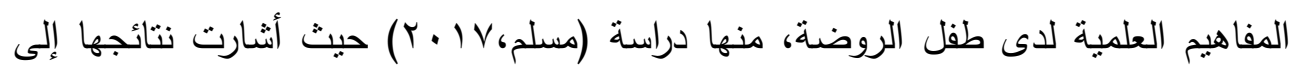
فاعلية خرائط التفكير كاستراتيجية في تكوين بعض المفاهيم البيولوجية لاى طفل الروضة،

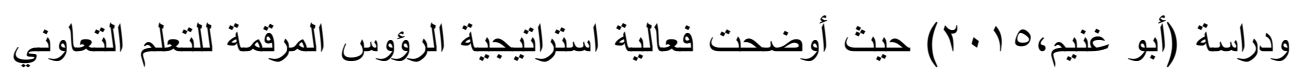
النشط في نتمية بعض مفاهيم علوم الحياة لدى طفل الروضة، كما أثنارت دراسة

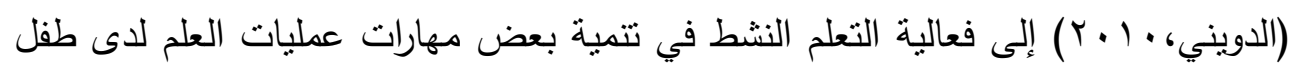

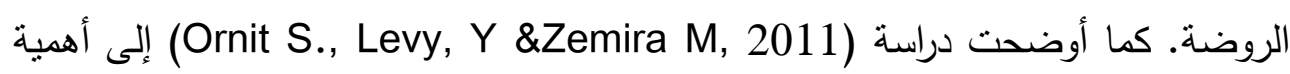
مشاركة الطفل ودوره الإيجابي في اكتساب المفاهيم العلمية بصفة عامة. وعلى مستوى طفل الروضة ضعيف السمع نلاحظ ندرة البحوث والدراسات التى ته تتتاول سواء تتمية المفاهيم عامة و العلمية بصفة خاصة، تركيز الدراسات على استراتيجيات

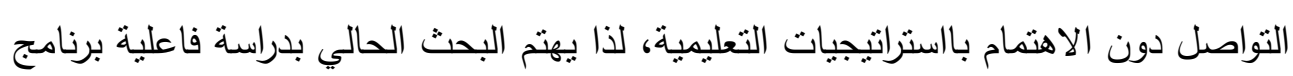

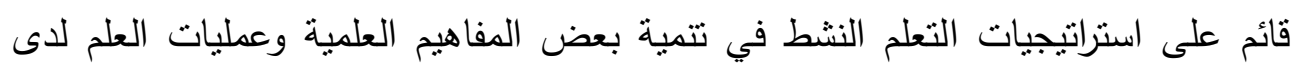
طفل الروضة ضعيف السمع.

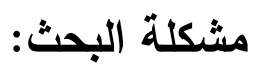

تتحدد مشكلة البحث من خلال إهتمام الباحثة بمجال التربية الخاصة عامة، وضعاف السمع خاصة، فمن خلال استعراض البحوث والدراسات التي تتاولت فئة المعاقين

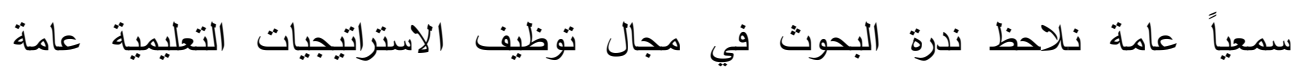
واستراتيجيات التعلم النشط بصفة خاصة في تتمية الجوانب المختلفة لثخصية المعاق

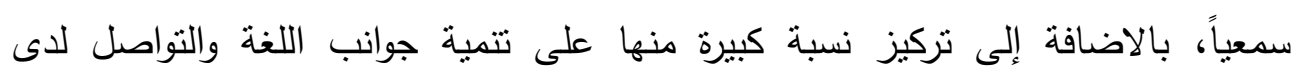
المعاقين سمعياً و ضعاف السمع وبصفة خاصة في مرحلة الطفولة المبكرة . ومن خلال دراسة استطلاعية لمراكز الصم و ضعاف السمع أثارت المعلمات إلى مجالات الأنشطة المقدمة لطفل الروضة ضعيف درائل السمع كما يلي: 


$$
\text { 1. أنثطة لغوية في مجالات الاستماع والتحدث والقراءة والكتابة (مهارات لغوية). }
$$

r. أنشطة رياضية تتعلق بالأعداد وبعض العمليات الحسابية الأساسية كالجمع والطرح. r. أنشطة حركية (الإيقاع الحركي) وتوظيفه في مجال تتمية لغة الطفل وبصفة خاصة مهارة التحدث والنطق، وتدريب مخارج الحروف. ء. أنشطة التدريب السمعي، تلك التى تركز على التمييز بين الحروف والكلمات والأصوات المختلفة. ه. الأنشطة منها الفردى و منها الجماعي. ج. واجبات منزلية تتعلق بمهارة الكتابة، سواء كتابة حروف أو كلمات. يتضح مما سبق تركيز أنشطة المركز على مجال اللغة سواء القراءة أو الكتابة بالاضافة إلى أنشطة التذريب السمعي، وتدريبات النطق والتخاطب، وأحياناً بعض الدفاهيم

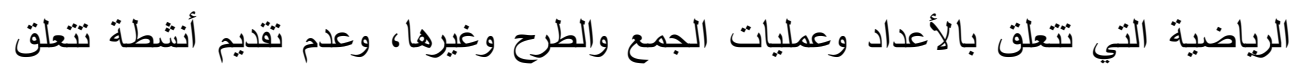

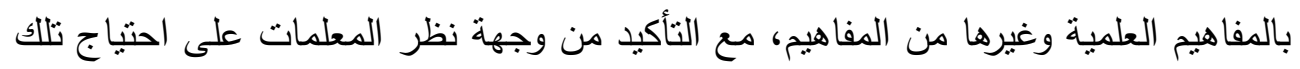

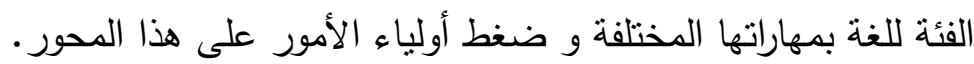
مما يوضح قصور الاهتمام بفئة المعاقين سمعياً عامة وضعاف السمع بصفة

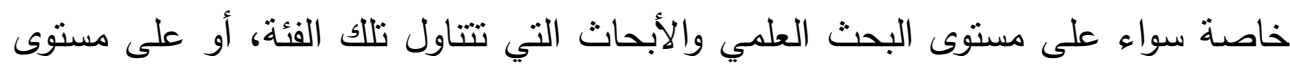

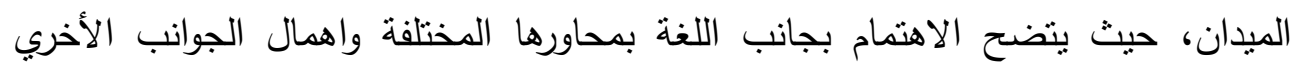
لثخصية أطفال هذه الفئة، هذا من جانب ومن الجانب الآخر نلاحظ تركيزها على لهانى استراتيجيات التواصل دون الاهتمام بتوظيف الاستراتيجيات التعليمية في مجال تتمية مفاهيم

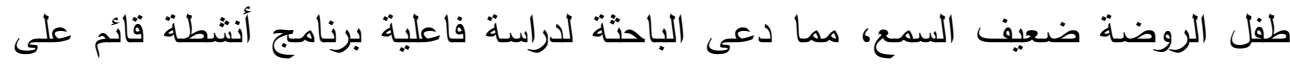
استراتيجيات التعلم النشط في تتمية بعض المفاهيم العلمية وعمليات العلم لدى طفل الروضة لبه

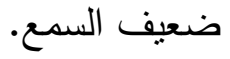


أسئلة البحث: تتحدد مشكلة البحث فى السؤال الرئيسى التالى: ما فاعلية برنامج قائم على استراتيجيات التعلم النشط في تتمية بعض المفاهيم

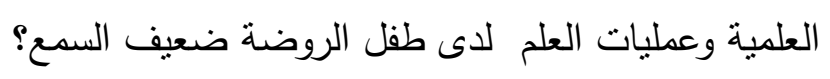
ويتفرع من هذا السؤال الاسئلة الفرعية التالية: - ما المفاهيم العلمية المناسبة لطفل الروضة ضعيف السمع ؟ - ما عمليات العلم المناسبة لطفل الروضة ضعيف السمح؟

- ما مكونات برنامج الأنشطة التعليمية القائم على استراتيجيات التعلم النشط لتتمية

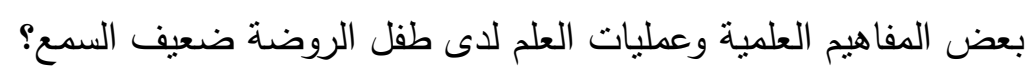
- - ما فاعلية استخدام بعض استراتيجيات التعلم النشط في تتمية بعض المفاهيم العلمية

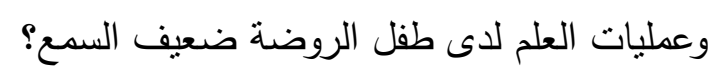
أهداف البحث: يهدف البحث الحالي إلى:

1. تحديد أهم المفاهيم العلمية وعمليات العلم المناسبة لطفل الروضة ضعيف السمع. r ـ تحديدعمليات العلم المناسبة لطفل الروضة ضعيف السمع. r. تحديد فاعلية برنامج قائم على استراتيجيات التعلم النشط في تتمية بعض المفاهيم

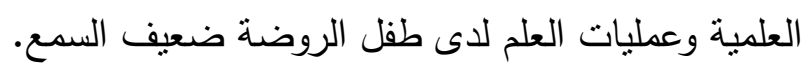
أهمية البحث: تظهر اهمية البحث الحالى فيما يأتى:

تكمن أهية البحث الحالى فى أهمية الموضوع الذى تتصدى له وهو مساعدة طفل

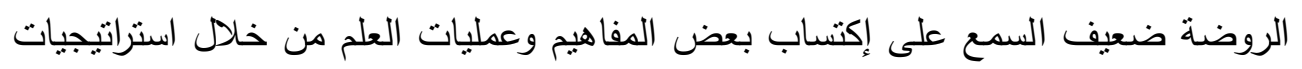
التعلم النشط ولا شك أن هذا الجانب يتضمن أهية كبيرة سواء أهمية نظرية أو أهمية تطبيقية. 
- - توجيه النظر إلى أهمية استراتيجيات التعلم النشط في تتمية بعض المفاهيم العلمبة وعمليات العلم لدى طفل الروضة ضعيف السمع.

- - الإهتمام بتقديم المفاهيم المختلفة وعمليات العلم بصفة عامة فى البرنامج اليومى لضعاف السمع في رياض الأطفال.

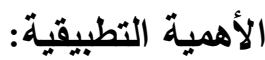

- تزويد معلمات ضعاف السمع في مرحلة رياض الأطفال ببرنامج أنثطة باستخدام

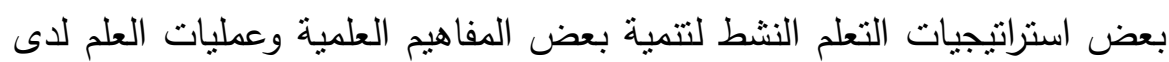
أطفال هذه الفئة.

- توفير مجموعة من المقاييس المناسبة لقياس مدى اكتساب طفل الروضة ضعيف السمع لبعض المفاهيم العلمية وعمليات العلم.

- توجيه نظر مصمدى برامج ومناهج وطرق تعليم ضعاف السمع إلى أهمية استخدام استراتيجيات التعلم النشط فى اكتسابهم المفاهيم و المهارات المختلفة.

\section{منهج البحث:}

يعتمد البحث الحالى على المنهج التجريبي (التصميم شبه التجريبي) الذى يعتمد على تصميم المجموعتين: التجريبية والضابطة لمناسبته لطبيعة هذا البحث، وباستخدام القباسين القبلى والبعدى لأفراد المجموعتين بهدف التعرف على فاعلية يرنامج قائم على ولى

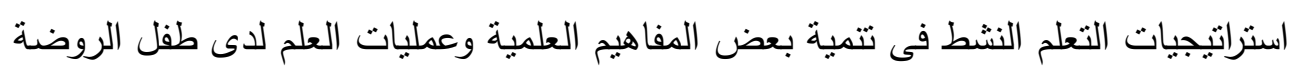
ضعيف السمع. 


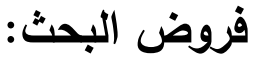

1. لا توجد فروق ذات دلالة احصائية بين متوسطات رتب درجات أطفال المجموعة

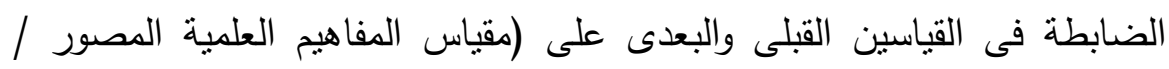
مقياس عمليات العلم).

r. توجد فروق ذات دلالة احصائية بين متوسطات رتب درجات أطفال المجموعة

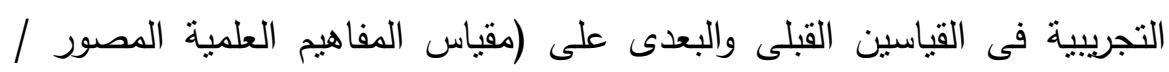
مقياس عمليات العلم) لصالح القياس البعدى. r. توجد فروق ذات دلالة احصائية بين متوسطات رتب درجات أطفال المجموعتين

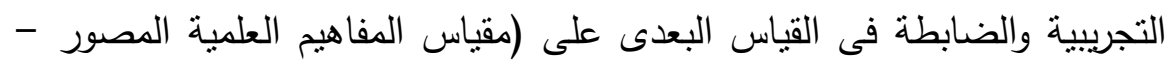
مقياس عمليات العلم) لصالح المجموعة التجريبية. عينة البحث:

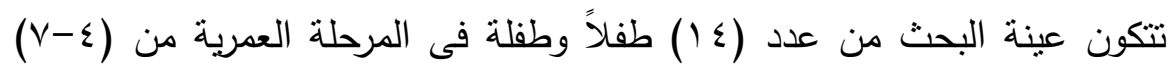

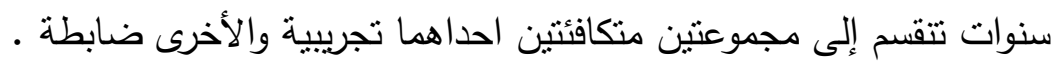
أدواث البحث:

1. مقياس ستانفورد - بينيه لقياس ذكاء الأطفال - الصورة الخامسة .(إعداد محمد

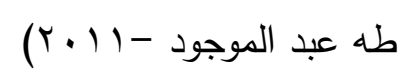

r. مقياس المفاهيم العلمية المصور لطفل الروضة ضعيف السمع. (إعداد الباحثة) r. مقياس عمليات العلم لطفل الروضة ضعيف السمع. إعداد الباحثة) ؛ . برنامج أنشطة تعليمية قائم على استراتيجيات التعلم النشط لتتمية بعض المفاهيم العلمية وعمليات العلم لطفل الروضة ضعيف السمع. إعداد الباحثة) 
حدود البحث: يلتزم البحث الحالي بالحدود الآتية:

1 - الحدود البشرية: اشتملت عينة البحث على (ع () طفلاً وطفلة من ضعاف السمع ممن تتراوح أعمارهم بين (ع - V) سنوات.

r- الحدود الجغرافية: تم تطبيق الدراسة الميدانية في مركز الصم وضعاف السمع بجمعية المبرات بمحافظة القاهرة، التابعة لوزارة الثئون الاجتماعية.

r- الحدود الزمنية: نم نطبيق البحث على مدى (^) أسابيع من فترة النشاط الصيفي

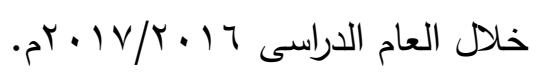

مصطلحات البحث: بستخدم البحث عدة مصطلحات ومفاهيم يجدر الإثارة إلى تعريفاتها

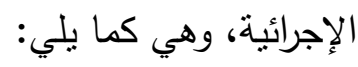

Hard of Hearing ضعيف السمع

يقصد بضعاف السمع في هذا البحث:"أولئك الذين تئدي حاسة السمع لديهم وظائفها ولكن بدرجة كفاءة أقل، فهم قادرون على فهم اللغة و الكلام باستخدام المعينات

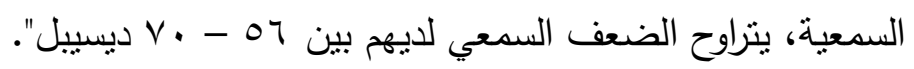

\section{Y. المفاهيم العلمية Scientific Concepts}

وتُعرف إجرائياً بأنها "مصطلح له دلالة معينة يختزل مجموعة من الصفات

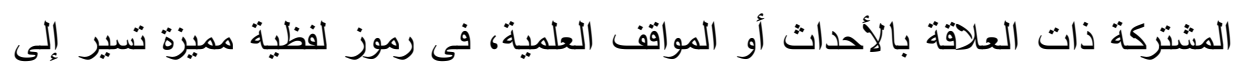
أفكار مجردة حول فئة من الموضوعات العلمية ذات العلاقة المشتركة".

\section{r. كمليات العلم Science operations}

تُعرف إجرائياً "مجموعة من العمليات العقلية البسيطة نسبياً في تعلمها، وتمثل الأساس في تعلم مهارات أخرى أكثر تعقبداً، وتُحدد بالمهارات التالية:الملاحظة، التصنيف، الاستتناج، وتقاس بالدرجة التي يحصل عليها الطفل في مقياس عمليات

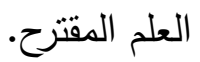




\section{الملاحظة Observing :}

وتعرف اجرائياً بأنها "العملية الأساسية التي يستخدم فيها الطفل جميع حواسه

أو بعضها للتوصل إلى معلومات عن العالم المحيط، والظواهر العلمية".

\section{التصنيف Classification}

وتعرف اجرائياً بأنه: العملية التي يقوم بها الطفل بتقسيم الأثياء و الأحداث

$$
\text { إلى مجموعات طبقاً لصفات معينة. }
$$

الاستنتاج Conclusion:

وتُعرف اجرائياً بأنه: هو العملية العقلية التي يتم فيها تفسير، وتوضيح الملاحظة، التى توصل إليها الطفل، معتداً على ما يعرفه من معلومات.

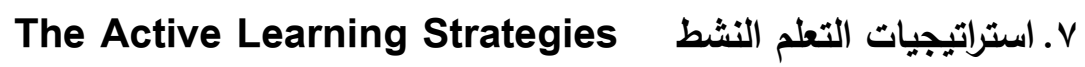

ويمكن تعريف استراتيجيات التعلم النشط اجرائياً في البحث الحالي بأنها : "كل

الأساليب التي تتطلب من طفل الروضة ضعيف السمع المشاركة بصورة إيجابية في المواقف التعليمية التي سبق تصميمها لاكتساب بعض المفاهيم العلمية وعمليات العلم قيد البحث تحت اثراف وتوجيه المعلمة "ويعتمد البحث الحالى على استراتيجيات: التعلم التعاونى، التعلم بالاكتشاف، الالعاب التعليمية.

: التعلم التعاوني

وتُعرف استراتيجية التعلم التعاوني اجرائياً بأنه: "طريقة تعلم تقوم على تتظيم أنشطة

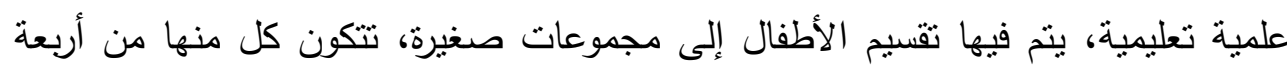

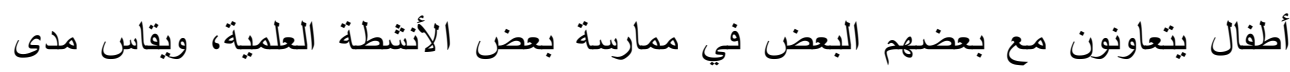

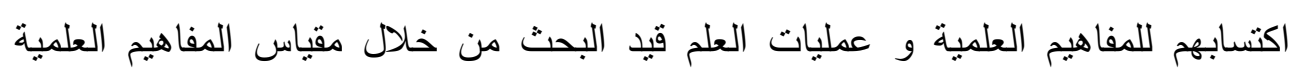
المصور ، ومقياس عمليات العلم المقترح". 


\section{التعلم بالاكتثناف :}

وتعرف استراتيجية التعلم بالاكتثاف اجرائياً بأنه: "طريقة تعلم تقوم على مواجهة

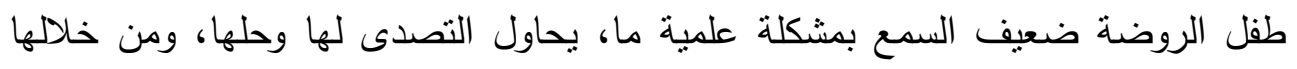

يكتسب بعض المفاهيم العلمية وعمليات العلم من خلال خطوات علمية منظمة " .

الألعاب التعليمبة :

وتعرف استراتيجية الألعاب التعليمية اجرائياً بأنها "نشاط تعليمى يشترك فيه

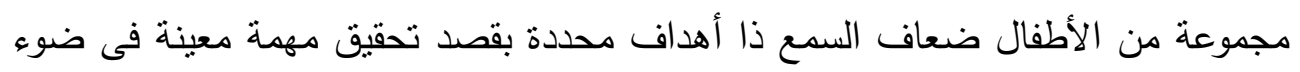

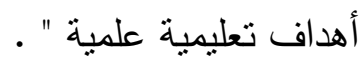

\section{الإطار النظرى والدراسات السابقة :}

\section{Hard of Hearing المحور الأول: ضعف السمع}

إن حاسة السمع هى من أهم الحواس بالنسبة للإنسان، ويؤكد ذلك دورها في المقام

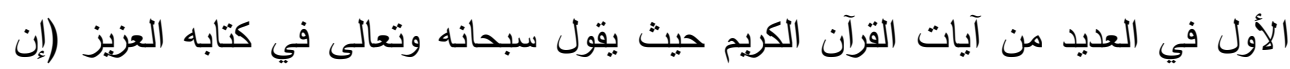

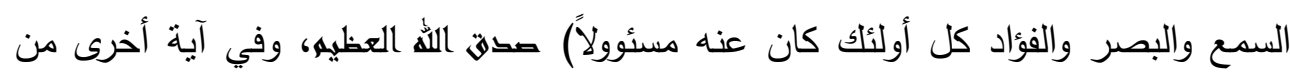

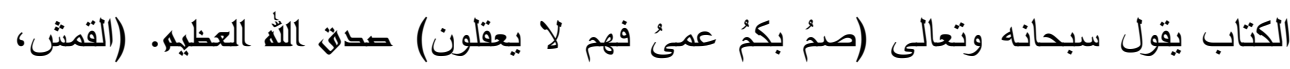

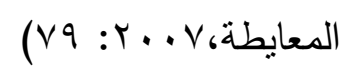

وحيث أن حاسة السمع هى التي تجعل الإنسان قادراً على تعلم اللغة وتمكنه من

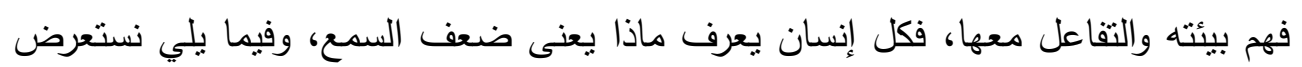
مجموعة منها.

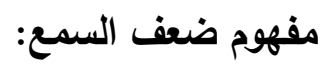

تعددت التعريفات الخاصة بضعف السمع، وفيما يلي عرض لبعض هذه التعريفات: 
ورد مفهوم ضعف السمع في القانون الاتحادي الأمريكي (9VV) بأنه "اعاقة

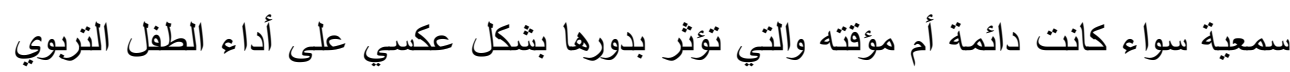

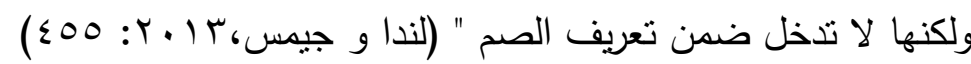

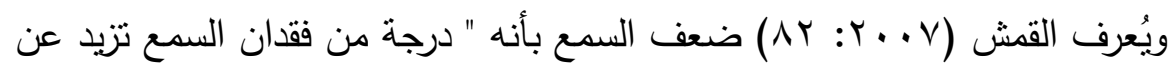

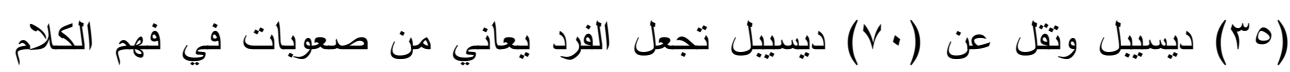
باستخدام حاسة السمع فقط، باستخدام السماعات أو بدونها".

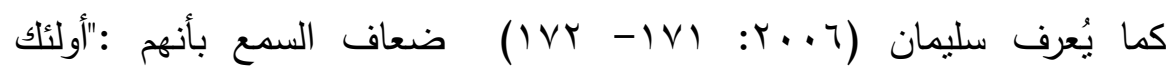
الأثخاص الذين تؤدى حاسة السمع لديهم وظيفتها بالاعتماد على أجهزة ومعينات سمعية طبية".

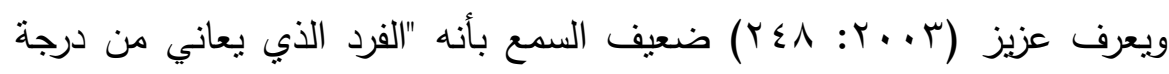

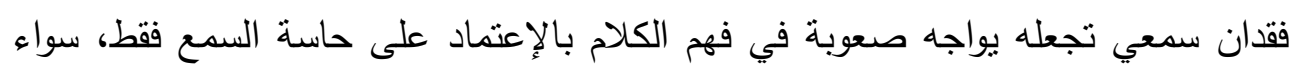

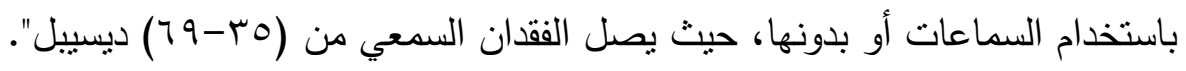

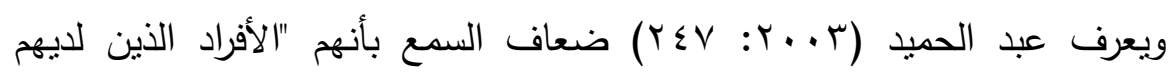
ضعف نسبي في حاسة السمع ويتطلبون بعض الغجراءات الخاصة حيث يمكنهم استخدام

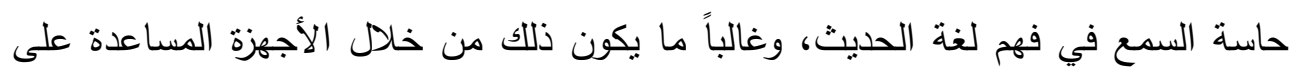
السمع".

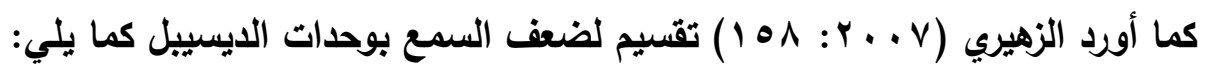
1. فقدان سمع عادي أو صعوبة سماع الأصوات الخاصة من (• (10-1) ديسيل. r. فقدان سمع خفيف أو صعوبة سماع الأصوات الخاصة و الكلام البعيد ومن ثم يجد هؤلاء الأطفال صعوبة في تتبع الدروس داخل الفصل من (0 ب- . ع) ديسيبل. r. فقدان سمع متوسط أو صعوبة في فهم الكلام المسموع من مسافات كبيرة أو عدم وضوحه من ( • ع- • V) ديسيبل. 
أ.م.د/ عبير صديق أمين

فاعلية برنامج قائم على استراتيجيات التطلم النشط

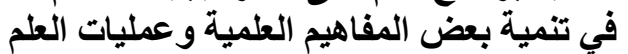
لاى طقل الروضة ضعيف السمع العية

ـ. فقدان سمع شديد أو عدم القدرة على سماع المحادثة وعدم القدرة على فهم كلام

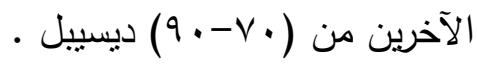

ه. فقدان سمع كلي أو عدم القدرة على تمييز نماذج الأصوات رغم ادراك الذبذبات

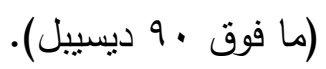

ومن خلال تعريفات ضعاف السمع نجد أنها تتفق في عدد من العناصر وهي:

- - ضعيف السمع غير محروم من أداء حاسة السمع لوظبفتها.

- ضعيف السمع قادر على فهم اللغة والكلام عن طريق استخدام المعينات السمعية. - تتراوح درجة فقدان السمع لدى ضعاف السمع بين (T-0 • V) ديسيل.

وبالتالي يمكنا تعريف ضعاف السمع اجرائياً بأنهم: "أولئك الذين تؤدي حاسة السمع وظيفتها بدرجة أقل، فهم قادرون على فهم اللغة و الكلام ومنابعة الأنشطة التعليمية

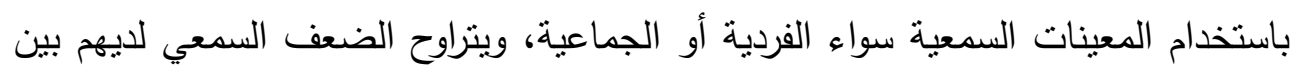

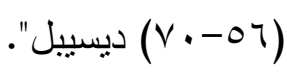

\section{تصنيفات الاعاقة السمعية :}

تعددت وجهات نظر العلماء والباحثين في تصنيف الاعاقة السمعية، فمنهم من

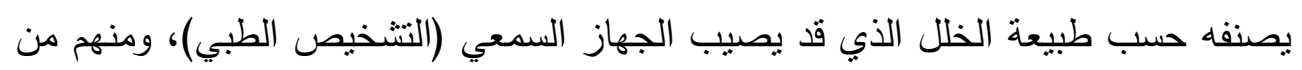

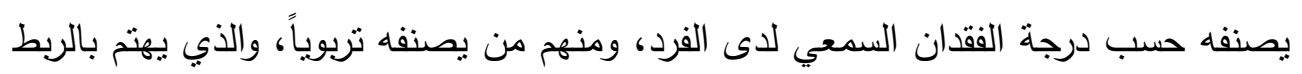

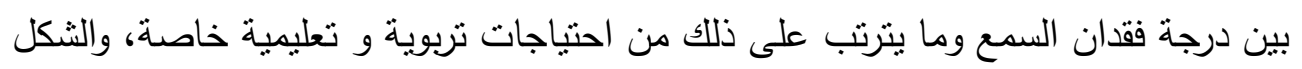
التالي يوضح التصنيفات المختلفة للاعاقة السمعية. 


\section{شكل (1)}

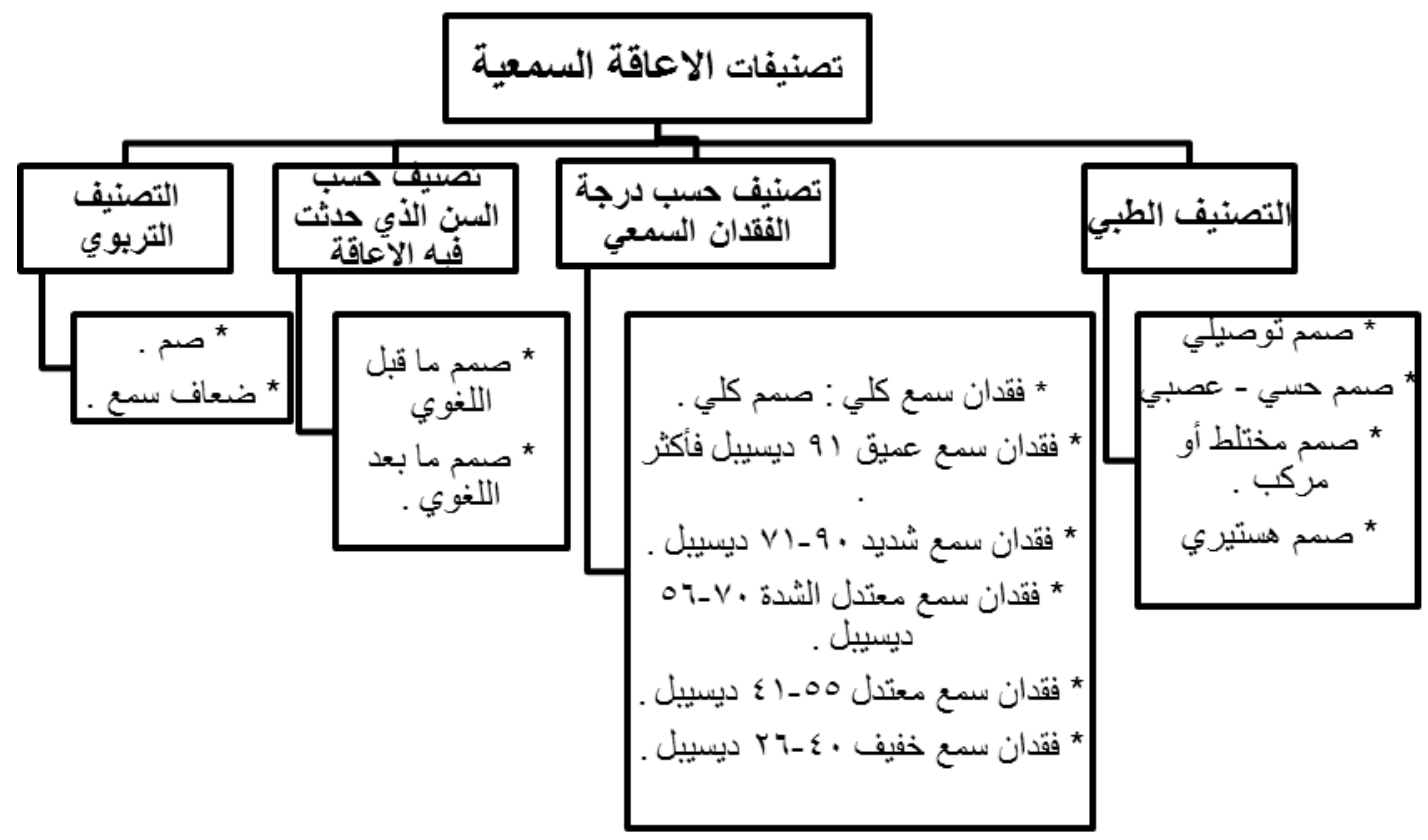

ويعتمد البحث الحالي على التصنيف التربوي الذي يصنف تللك الفئة إلى : صم

وضعاف السمع، ويهنم البحث بفئة ضعاف السمع ممن يتراوح مستوى الضعف السمعي

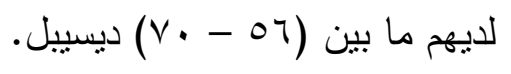

أعراض صعوية السمع: الأعراض الظاهرة للمصاب بصعوبة السمع نتمل: • استجابة الثخص للصوت غيرثابتة، فقد يسمع كلمة بوضوح بينما لا يسنطيع فهم

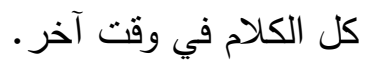

تأخر الطفل في تطور اللغة والكلام.

$$
\text { كلام الشخص غير واضح. }
$$

يرفع الثخص صوت الراديو والتلفاز دون وجود ضجة حوله.

عجز الثخص عن تنفيذ التوجيهات، سواء كان عجزاً ناماً أو جزئياً. 
الثخص دائم الاستفسار بعبارات مثل "ماذا؟ " عند سؤاله عن شيء أو عند توجيه

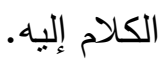

عدم استجابة الثخص عند مناداته حتى لو كان في النداء تحذير من مخاطر أو توصيل أمر يهمه إلى مسامعه.

برفع الثخص صوته عند الكلام بدون مبرر •(اليوبي، • 1 ـ ب: 7 ( )

\section{خصائص ضعاف السمع:}

يؤثر فقدان القدرة اللغوية نتيجة لضعف السمع، بشكل فعال على المظاهر السلوكية الأخرى للفرد، وفيما يلي نستعرض أثر ضعف السمع على جوانب شخصية الفرد:

أثثر ضعف السمع على النمو اللغوي: تتأثز مظاهر النمو اللغوي بدرجة ضعف السمع، فكلما زادت درجة ضعف السمع كلما زادت المشكلات اللغوية، والعكس صحيح، وعلى ذلك لك يواجه الأفراد ذوو ضعف السمع البسيط مشكلات في سماع الأصوات المنخفضة أو البعيدة

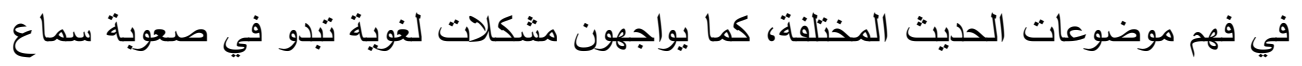

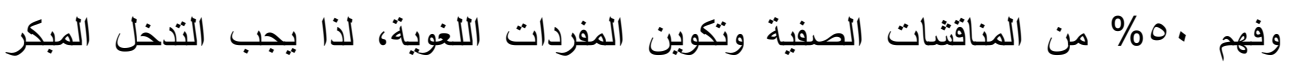
باكتثاف ضعف السمع واستخدام المعينات السمعية المناسبة حيث أثنارت دراسة

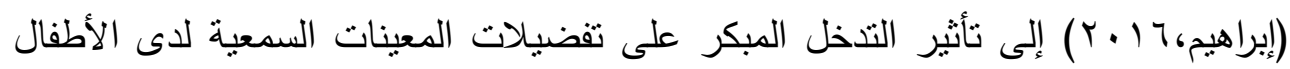

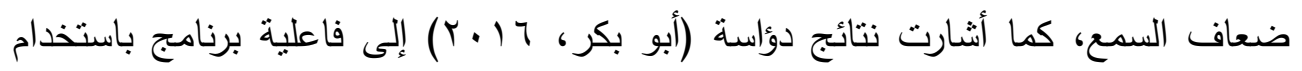
Telecoil loop System ضعاف السمع، ودراسة (حماده، Y 1 ب Y) حيث أوضحت فاعلية برنامج تدريبي لتتمية مهارات

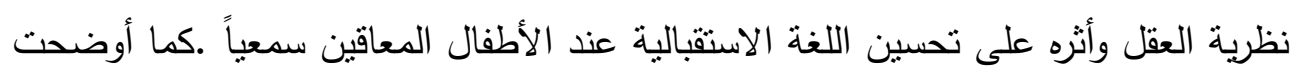

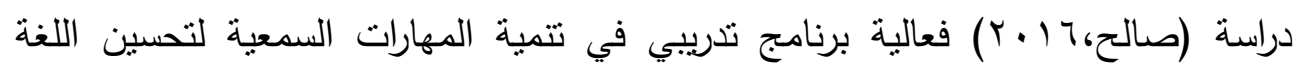

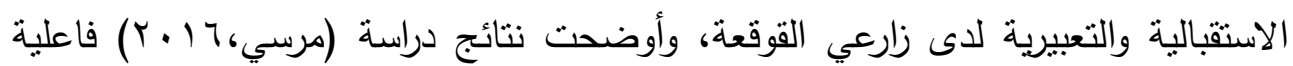

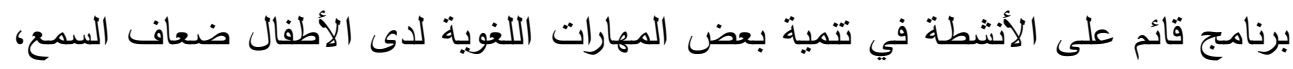

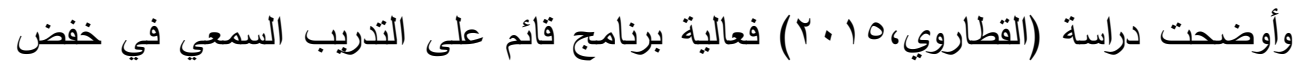

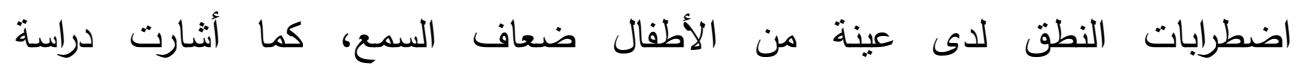




\section{المجلة العلمية لكلية رياض الاطفال - جامعة اسيوط}

(عوض، \& ( ب) فاعلية برنامج لتتمية المهارات اللغوية الاستقبالية والتعبيرية لدى أطفال الروضة المعاقين سمعياً، في حين يواجه الأفراد ذوو الإعاقة السمعية المتوسطة مشكلات

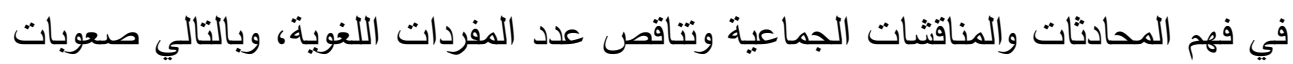
في التعبير اللغوي، في حين يواجه الأفراد ذوو الإعاقة الثديدة مشكلات في سماع الأصنات التهات

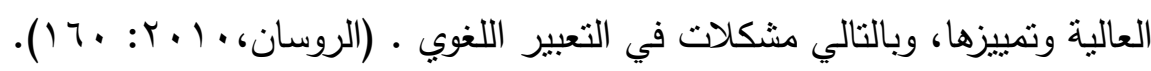

أثثر ضعف السمع على القرة اللفوية: يثي كثثر من علماء النفس التربوي إلى لى

إرتباط القدرة العقلية بالقدرة اللغوية، ويعني ذلك تدني أداء ضعاف السمع على اختبارات

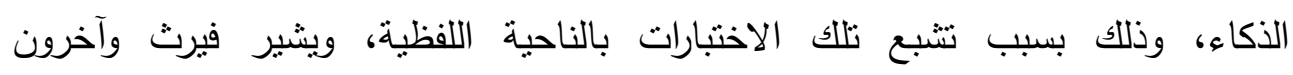
(Furth,1973) بالرغم من الصعوبات التي يواجهها الصم في التعبير عن بعض المفاهيم وخاصة المفاهيم المجردة، كما يشير فيرث أيضاً إلى أن الفروق في الاداء بين ضعاف السمع والعاديين تعود

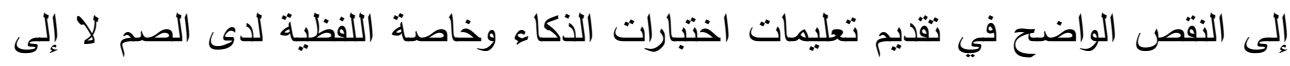

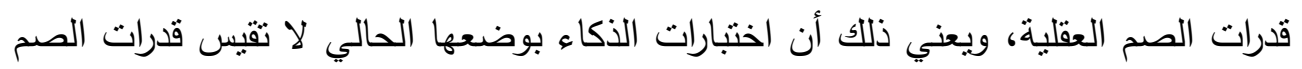
العقلية الحقيقة إلا إذا صمدت بطريقة تتاسب درجة اعاقتهم السمعية وخاصة الاختبارات

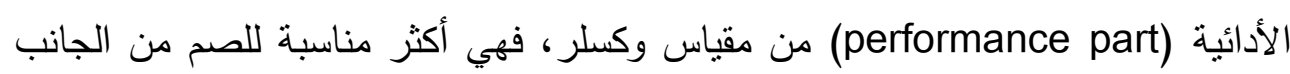
اللفظي (Verbal Part) من المقياس نفسه، وعلى ذلك كله يصعب اعتبار الصم معاقين

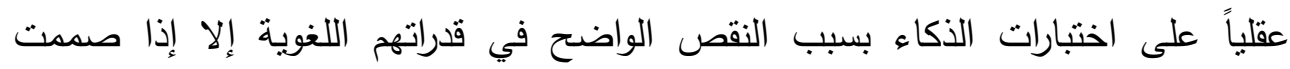
اختبارات عقلية خاصة يضعاف السمع و الصم. مما لا ينتاقض مع ما أثنارت إليه نتائج

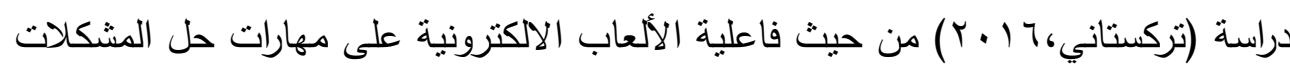

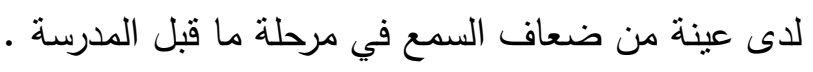
أثثر ضعف السمع على الجوانب الجسمية والحركية: لا يتمتع الأشخاص الصم وضعاف السمع باللياقة البدنية مقارنة مع الأشخاص العاديين، ويعاني ضعاف السمع من ضعف في التآذر الحركي، وتبلغ نسبة الأطفال المصابين بضعف التآذر الحركي نحو

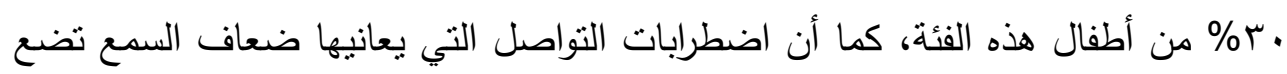
حواجز وعوائق كبيرة أمامهم لاكتشاف البيئة والتفاعل معها، وفي حالة عدم استخدام 
استراتيجيات بديلة للتواصل مع ضعاف سمع فإن مشكلة ضعف السمع قد تفرض قيوداً على (النى

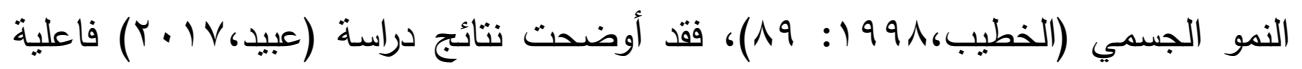
برنامج مقترح على بعض المتغيرات البدنية و المهارية و المعرفية على جهاز الحركات

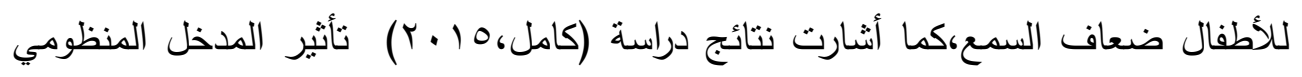

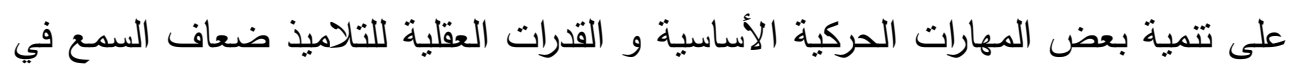
درس التربية الرياضية.

أثثر ضعف السمع على التكيف الاجتماعي والمهني: تعتبر اللغة وسيلة أساسية من وسائل الإتصال الاجتماعي، وخاصة في التعبير عن الذات وفهم الآخرين، ووسيلة

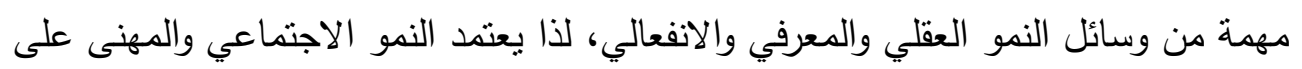

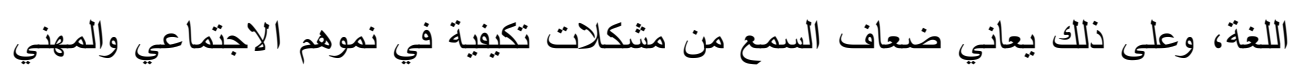

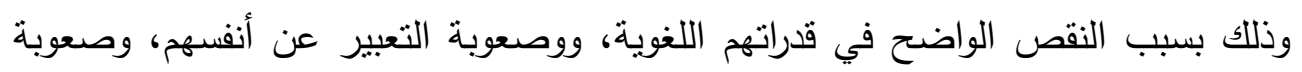

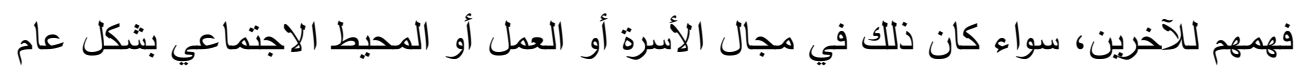

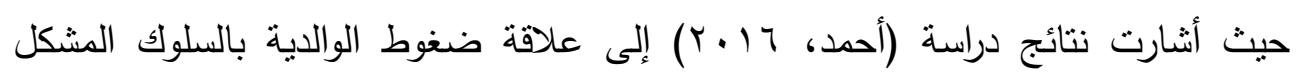

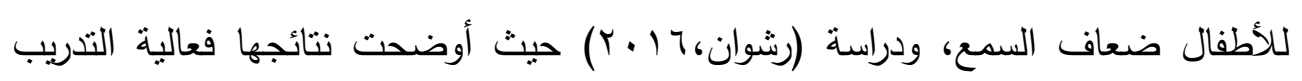
على مهارات الوعي الفونولوجي في تتمية الاستخدام الاجتماعي للغة لدى الأطفال ضعاف

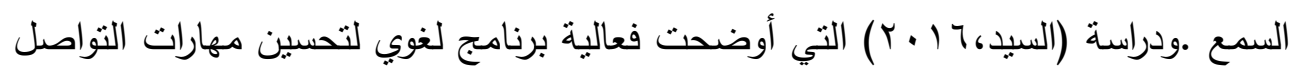

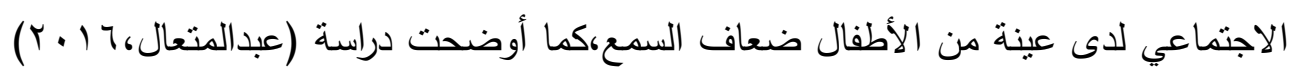

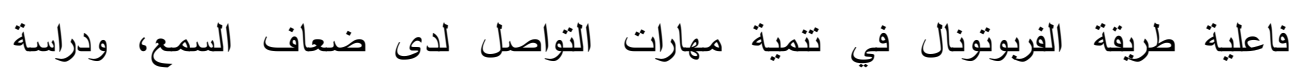

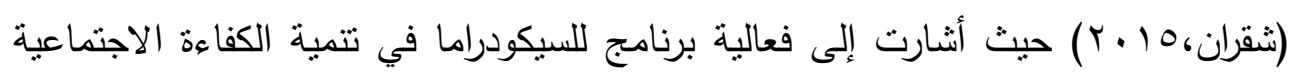

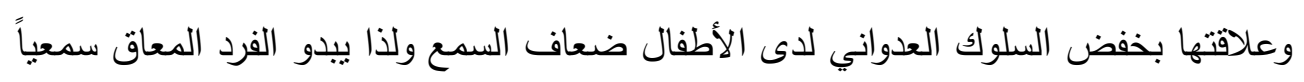

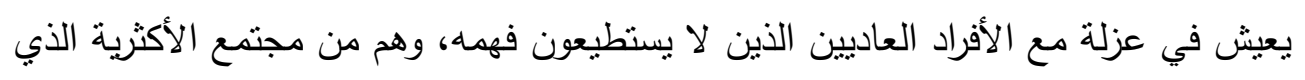

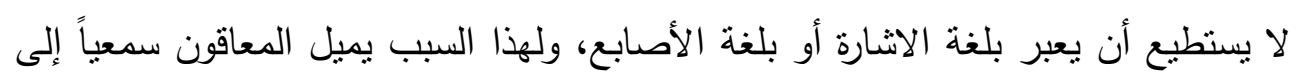

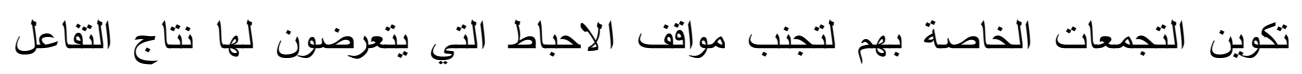

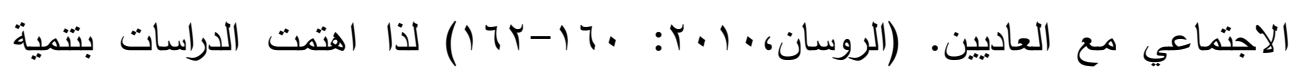

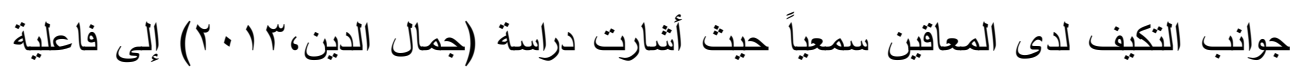


برنامج باستخدام تدريبات الفربونونال في تتمية السلوك التكيفي لدى الأطفال ضعاف السمع،

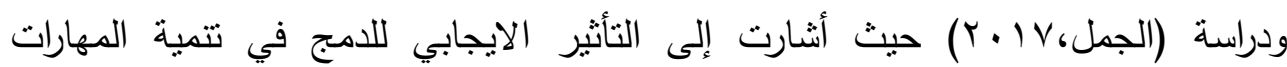

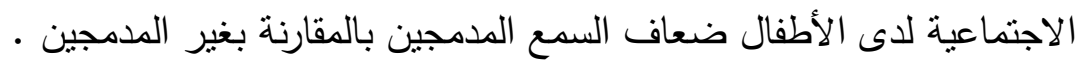

أثر ضعف السمع على التحصيل الأكاديمي: لها كانت جوانب التحصيل الأكاديمي

مرتبطة بالنمو اللغوي فمن الطبيعي أن تتأثز الجوانب التحصيلية لضعاف السمع وبصفة التئي

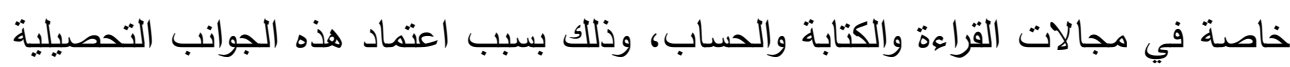

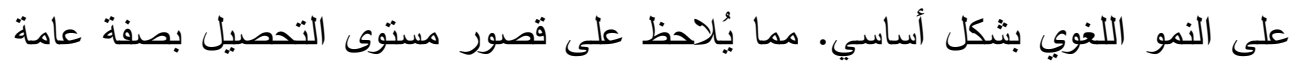
وفي جانب المفاهيم خاصة.

وقد أثنارت الدراسات إلى أن ضعاف السمع يكتسبون المفاهيم بنفس درجة التسلسل

التقليدي لدى العاديين إلا أن اكتساب ضعاف السمع للمفاهيم المختلفة يتم فى أعمار زمنية أكبر من العاديين، كما أنهم يعانون من صعوبات فى اكتساب الدفاهيم المتتاقضة والمفاهيم المتشابهة ودمج بعض المفاهيم مع بعضها البعض. ويتضح من تلك الدراسات أن فقدان

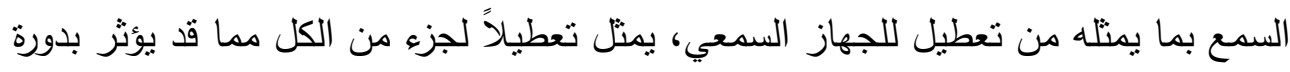

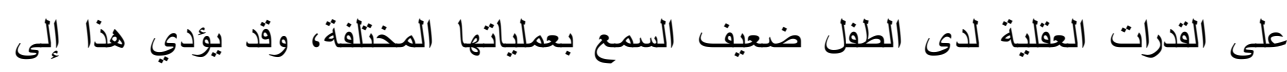
اضطراب تلاك القدرات، وأن يصبح نموها غير كامل وغبر ناضج، ( Deafness and Hearing Impairment,2006) وعمليات العلم لدى طفل الروضة ضعيف السمع.

المحور الثاني: المفاهيم العلمية وعمليات العلم:

تعد المفاهيم العلمية جوهر العملية التعليمية، والتي يبني عليها تعلم باقي المعارف المختلفة، ويرجع هذا إلى أن المفاهيم العلمية أحد المكونات الأساسية للهيكل المعرفي للعلم

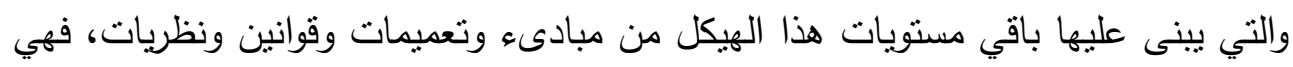

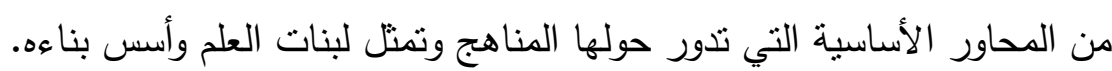
حيث أنثارت دراسة (Jong , T ., Linn ,M ., Zacharia ,C.2013) إلى

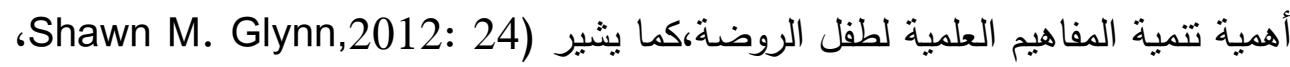


Reinders Duit

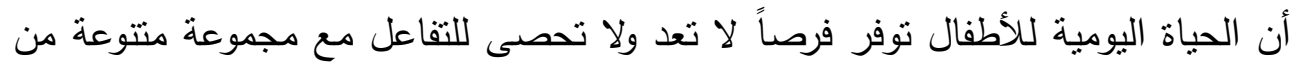

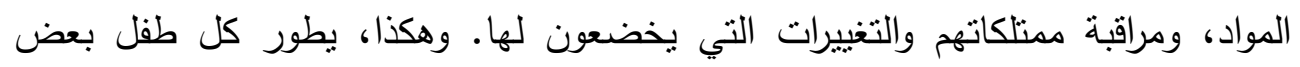
الأفكار البديهية حول المادة. فالمفاهيم تمثل معنى العلم وتحقق وظيفته في الملاحظة والتفسير والضبط والتتبؤ بالظواهر الطبيعية، وتساعد على انتقال أثر التعلم، وعلى تتظيم

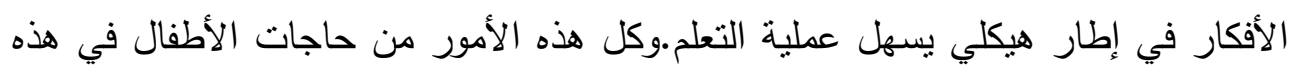
المرحلة والتي يجب إنباعها.

ويتكون المفهوم العلمى لدى الفرد من معنى وفهم يرتبط بكلمات أو عبارات أو

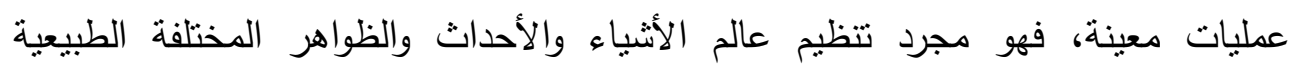

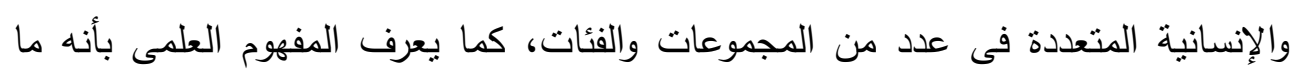
يتكون لدى الفرد من معنى وفهم يرتبط بكلمة (مصطلح) أو عبارة عن عملية معينة مثل بعل فئل

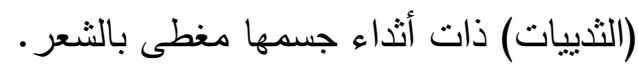

كما يتضح المفهوم العلمى من خلال معرفة خصائص المفاهيم، وهى: - يتكون المفهوم العلمى من جزئين الإسم أو المصطلح مثل (الكثافة، الخلية،

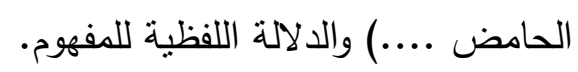

- - يتضمن المفهوم العلمى التصميم متل: مفهوم المادة، فهى كل شئ يشغل حيزا، وله تقل ويمكن إدراكه بالحواس.

- - لكل مفهوم علمى مجموعة من الخصائص المميزة التى يشترك فيها جميع أفراد فئة

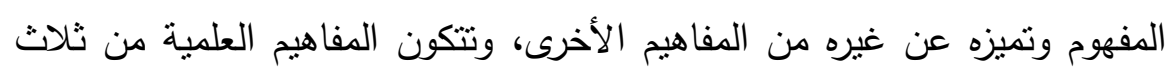

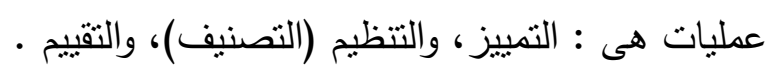
- تكوين المفاهيم العلمية ونموها عملية مستمرة تتدرج فى الصعوبة من صف إلى تصلى صف، ومن مرحلة تعليمية، إلى أخرى وذلك نتيجة لنمو المعرفة العلمية نفسها

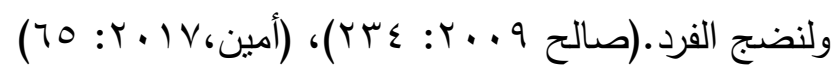


أهمية المفاهيم العلمية : يمكن تحديد أهمية المفاهيم العلمية فى الآتى: ا. تقلل من تعقد البيئة إذ أنها تصنيف ما هو موجود من أثنياء ومواقف.

r. تعد من الوسائل التى تعرف بها الأثياء الموجودة فى البيئة . r. تقلل الحاجة إلى إعادة التعلم عند مواجهة أى موقف جديد. ؛. تناعد على التوجيه والتتبؤ والتخطيط لأى نشاط. ه. تسمح بالتنظيم والربط بين مجموعات الأشياء والأحداث.

\section{صعويات تعلم المفاهيم العلمية:}

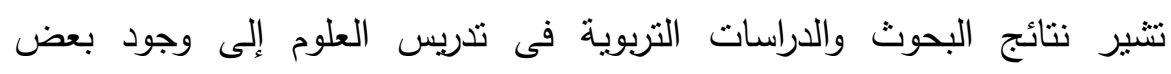
الصعوبات فى تعلم المفاهيم العلمية وإكتسابها، وذللك نظرا لتفاوت المفاهيم العلمية نفسها من لُّني حيث أنواعها وبساطتها، وتعقيدها أو تجريدها، ومن الصعوبات التى نواجه المتعلم فى تعلم وإكتساب المفاهيم العلمية نذكر ما يلى:

• طبيعة المفهوم العلمى، ويتمنل فى مدى فهم المتعلم للمفاهيم العلمية المجردة أو

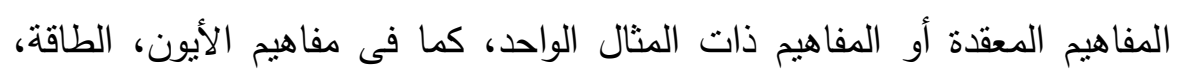

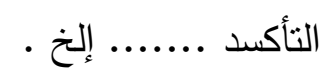

• الخلط فى معنى المفهوم أو الدلالة اللفظية لبعض المفاهيم العلمية وخاصة تلك كالك المفاهيم التى تستخدم كمصطلحات علمية كلغة محكية بين الناس كما فى مفاهيم :

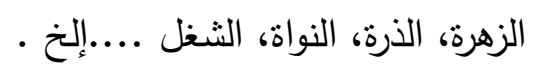

• النقص فى خلفية المتعلم النقافية، فمثلا عندما يدرس المتعلم مفهوم الإنصهار، فإن

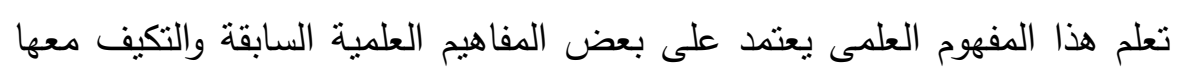

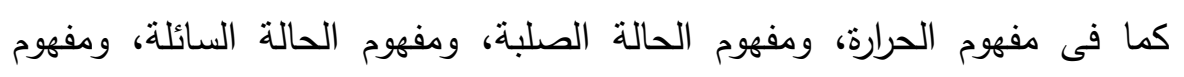
التغير الطبيعى. 
• العوامل اللغوية أو لغة التعليم تعتبر لغة التدريس (العربية) من العوامل الخارجية التى قد تؤثر فى إستيعاب المتعلمين للمفاهيم العلمية، وخاصة عند تدريس لتهن

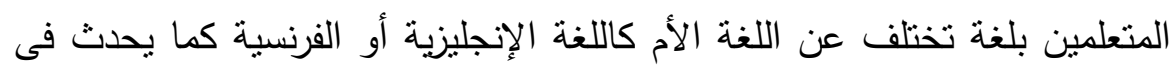
بعض الدول العربية، كما أن اللهجات التى بيتخدمها المعلمون قد تؤثر أيضا فى الإنى

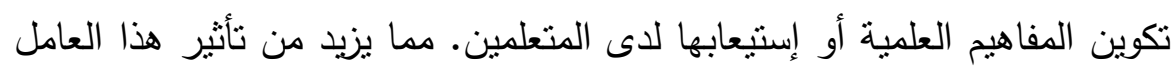

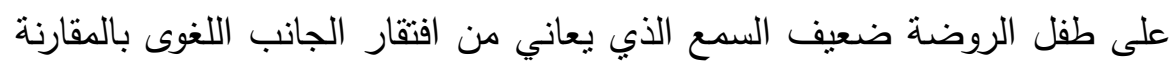
بطفل الرروضة من عادي السمع.

•صعوبة تعلم المفاهيم العلمية السابقة اللازمة لتعلم المفاهيم العلمية الجديدة، أما مصدر صعوبات تكوين المفاهيم العلمية فتتجم معظم هذه الصعوبات عن عوامل خارجية بالنسبة للمنعلم، وبالتالى ليس له سلطان عليها ومن بين هذه الصعوبات

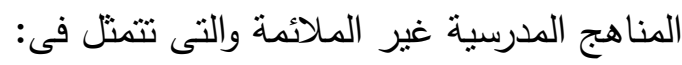

م مقررات منهجية لا نراعى الخبرات والخلفيات المباشرة للمتعلمين بدرجة مناسبة .

م قد لا تتمشى مفاهيم المناهج المقررة مع المستويات الحقيقية للمتعلمين. م يمكن أن تتضمن نشاطات علمية قد لا تستطيع غالبية المتعلمين القيام بها. م نوقع المسئولين والمعلمين وأولياء الأمور أن يتعلم المتعلمين قدرا كبيرا من

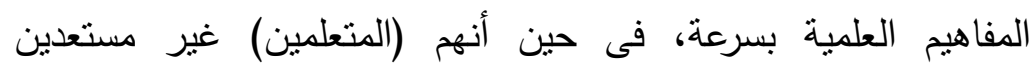

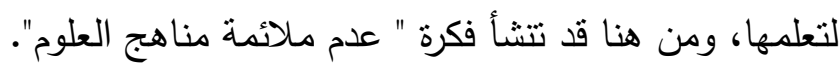
م قد تبنى المناهج والدقررات الدراسية (أو تسنعار) من المناهج الأجنبية، دون أن تأخذ اختلاف الثقافات والإمكانات المادية والفنبة بعين الإعتبار . م معلمو العلوم أنفسه، ويرتبط هذا العامل بطرق التذريس التى يتبعها أو يطبقها المعلمون فى ممارستهم التدريسية الصفية والمعملية، وقد يرجع أيضا إلى عوامل أخرى فى المعلمين أنفسهم كما فى معلى 


\section{المجلة العلمية لكلية رياض الاطفال - جامعة اسيوط}

$$
\text { O مؤهلات المعلمين دون المستوى المطلوب. }
$$

م مدى توافر الحوافز الداخلية لاى المعلم، ومدى دافعيته، وارتباطه بمهنة

$$
\text { التعليم. }
$$

أما العوامل الداخلية التى تسهم فى صعوبات تكوين المفاهيم لدى المتعلمين فعلى اختلاف الباحثين فيها، تتمثل بمدى إستعداد المتعلم نفسه ودافعيته للتعلم بوجه عام، وتعلم المفاهيم العلمية بوجه خاص، وكذلك مدى اهتمامه وميوله للمواد العلمية وتعلم مفاهيمها. هذا بالإضافة إلى البيئة والثقافة التى يعيش فيها المتعلم التى قد لا تشجع أو

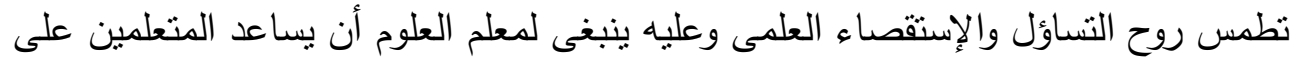
تكوين المفاهيم العلمية وتمنلها، وذللك بربطها بالخبرات المألوفة للمتعلمين وبالتالى الإنطلاق من خبرات المتعلمين أنفسهم.

بناء على ما تقدم، ونتيجة لوجود بعض الصعوبات فى تعلم بعض المفاهيم

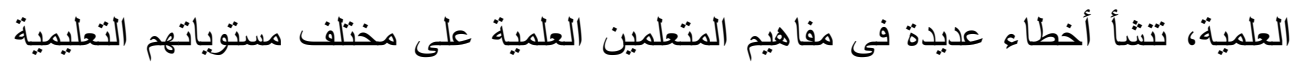

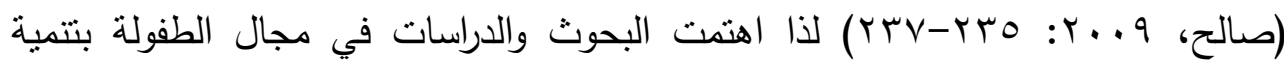
المفاهيم العلمية بأنواعها المختلفة لدى طفل الروضة منها دراسة. طرق التدريس، تؤثز طرق وأساليب التدريس التقليدية السائدة كما فى الإلقاء،

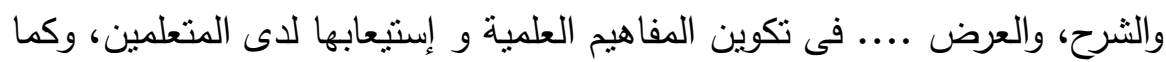

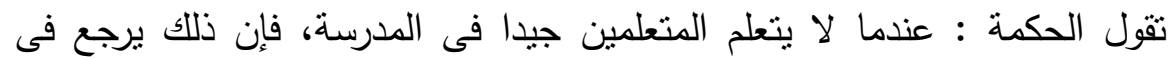

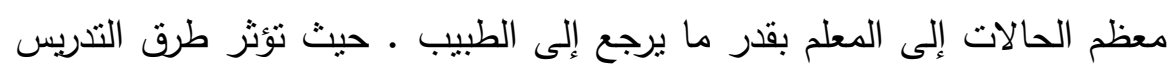

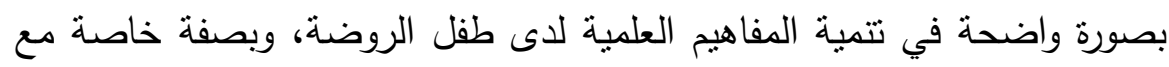
طفل الروضة ضعيف السمع حيث ينطلب هذا المحور استخدام استراتيجيات تعليمية تتسم بالفاعلية والايجابية و المشاركة من المتعلم، لذا كانت تتمية المفاهيم

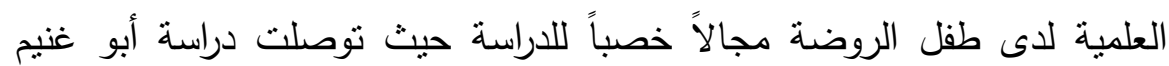

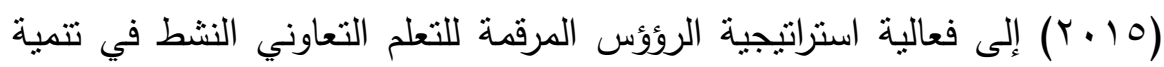




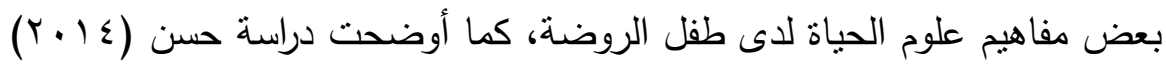

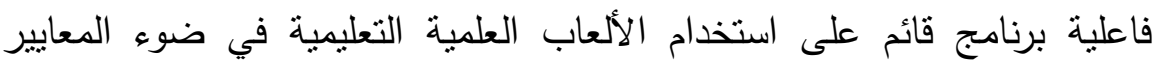
القومية في اكتساب المفاهيم العلمية وتتمية بعض مهارات عمليات العلم الأساسية والتفكير الابتكاري لدى أطفال الروضة، وأوضحت دراسة (Ni Chang , 2012)

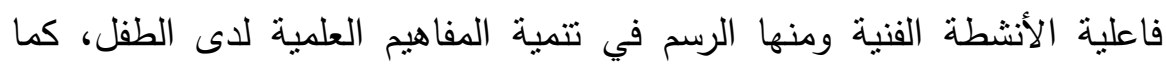

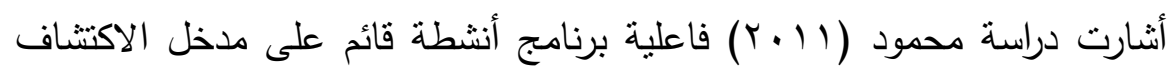
لتتمية بعض المفاهيم والتقكير الاستقرائي لدى أطفال ما قبل الددرسة. لذا يعتمد البحث الحالي على توظيف مجموعة من الاستراتيجيات التعليمية في تتمية المفاهيم العلمية وعمليات العلم لدى طفل الروضة ضعيف السمع. وقد أكد كثير من التربوبين على أهية المفاهيم حيث ذكر (سلامة ؟ . . Y : OV) أن تعلم المفاهيم يساعد المتعلم على التفسير والتطبيق ويزيد من دافعيتهم ويحثهم على اهلى

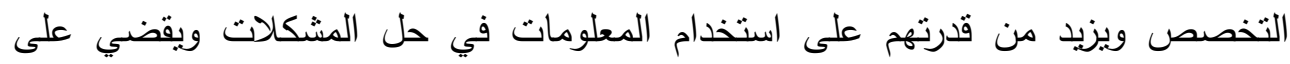
اللفظية ويقلل من تعقد البيئة وسهولة دراسة مكوناتها.

فمن الضروري تزويد المتعلم بالمعارف العلمية بصورة وظيفية، فالمتعلم يحتاج إلى امتلاك مهارات وقدرات عقلية خاصة، وفي حالة عدم امتلاكها وممارسها فإنه يواجه كثيراً

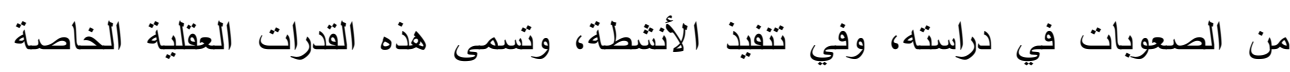
بعمليات العلم، لذا فإن استراتيجيات التدريس الفعالة يجب أن تهتم بعمليات العلم، لأنها

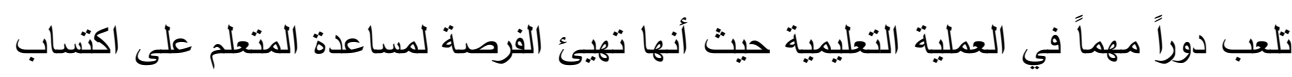
المعلومات بنفسه، وتتمي عند المتعلم حب الاستطلاع، والبحث عن المسببات التي تكمن وراء الظواهر ، واكتساب المتعلم لهذه العمليات ينتقل أثره إلى مواقف تعليمية أخرى.

وفيما يتعلق بالمعاقين سمعياً بصفة عامة وضعاف السمع خاصة نجد أن من أهم استراتيجيات التدريس هو الاعتماد على توجه الصم وضعاف السمع إلى التعبيرات المرئية بصورة فريدة، لتعويض العجز عن الوصف الكلامي، سواء المنطوق أو المكتوب، وبهذا

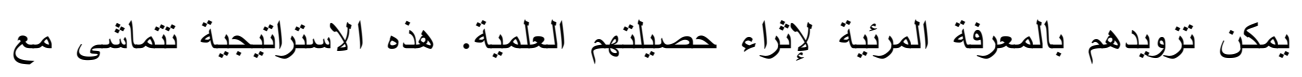


استراتيجيات التعليم الحديثة الخاصة بالمعافين في أسماعهم، حيث تتحور وسائل الإيضاح في العديد من المجالات في استخدام الصور والفيديو والنماذج المجسمة، والرسوم البيانية والإيضاحية . (Mclntosh, R.A.,2005 ) بما يشجع تفاعل المتعلم في العملية التعليمية،

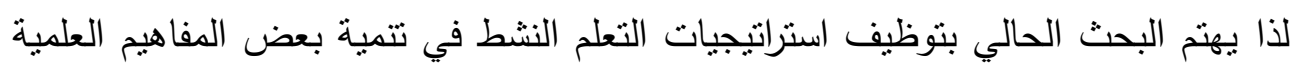

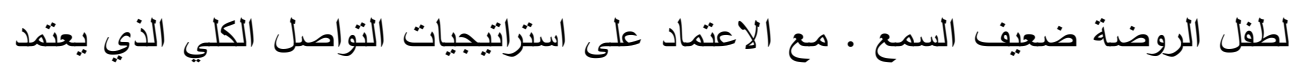

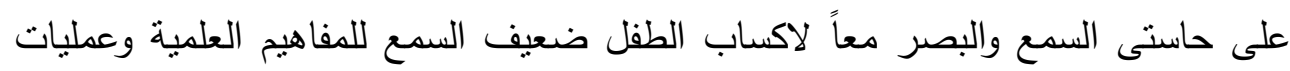

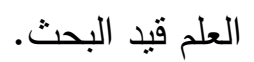

\section{أهداف مجال العلوم في رياض الأطفال: - أن}

1. اكتساب الأطفال لبعض المفاهيم العلمية مثل مفاهيم: الحيوان،النبات، الماء،

$$
\text { الهواء الجوى، الصوت، المغناطيسية. }
$$

r. معرفة الأطفال لأهمية المفاهيم العلمية في الحياة اليومية.

r. تتمية وتدريب حواس الطفل المختلفة.

؛. تدريب الأطفال على ملاحظة الأشياء وتداولها للتعرف عليها.

ه. تعويد الأطفال على الأسلوب العلمي في التفكير (التساؤل - البحث - التجريب

$$
\text { - الاكتشاف). }
$$

צ. تدريب الأطفال على التجريب بالمعنى البسيط الذي يتتاسب مع قدراتهم

$$
\text { ومداركهم. }
$$

V. مساعدة الأطفال على اكتساب بعض الاتجاهات والميول العلمية.

^. تتمية قدرة الأطفال على تفسير بعض الظواهر العلمية.

يتضح من أهداف مجال العلوم في رياض الأطفال ارتباط المفاهيم العلمية بعمليات

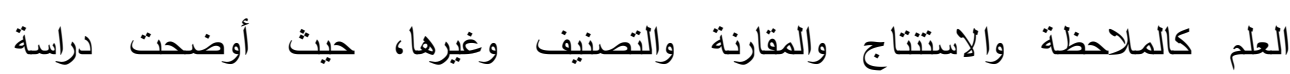

(Bulunuz,M, 2013) العلمية والعكس، أن الاعتماد على مهارات العلم وتتميتها لدى الطفل يساهم في اكتسابه 
للمفاهيم العلمية حيث اوضحت نتائج الدراسة أن الاعتماد على البيئة وملاحظة محتواها والمقارنة بين عناصرها ساهم بصورة واضحة في تتمبة بعض المفاهيم العلمبة عامة ومفهوم الطفو والغوص بصفة خاصة، لذا يهنم البحث الحالي بدراسة فاعلية استخدام استراتيجيات

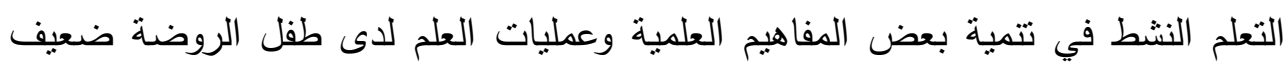

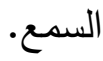

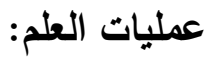

أشتار برونر Bruner إلى أن عمليات العلم عبارة عن عادات تعليمية يكتسبها

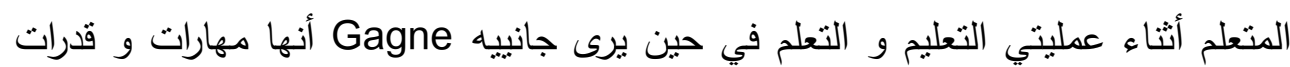
عقلية متعلمة (على، r. . T.

في حين تمثل عمليات العلم عند جانييه المكونات الأساسية للتحقق العلمي، وصولاً

إلى الاستتناجات و التصورات العقلية المختلفة، وهي مهارات قابلة للتعميم، وتسمى مهارات عمليات العلم Science Process Skills بمهارات التعلم ددى الحياة، حيث يمكن

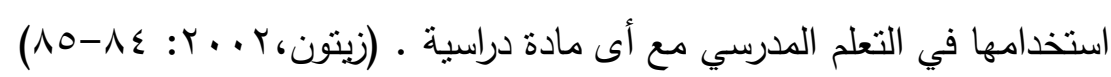

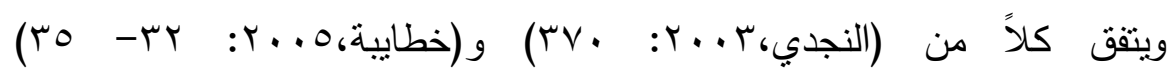

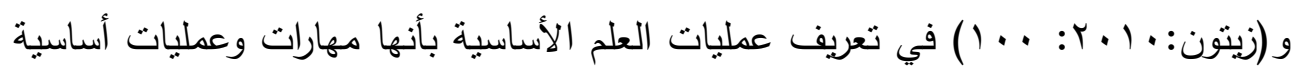
تأتي في قاعدة هرم تعلم العمليات.

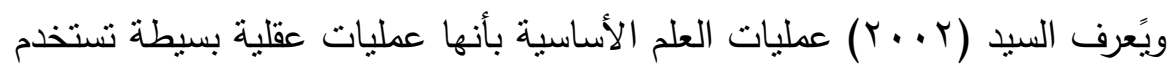

في مراحل التعليم الأولى، حيث يسهل اكتسابها، وتعلمها، وتتشل ثماني عمليات هي : الملاحظة، التصنيف، القياس، التواصل، الاستدلال، التتبؤ، استخدام علاقات الزمان

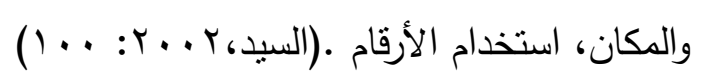

ويمكن تعريفها اجرائياً بأنها : مجموعة من العمليات العقلية البسيطة نسبياً في

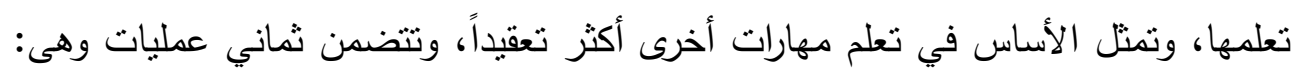
الملاحظة، التصنيف، الاتصال، القياس، استخدام الأرقام، استخدام العلاقات المكانية 
والزمانية، الاستتناج، التتبؤ .ويتتاول البحث الحالي عمليات الملاحظة، التصنيف، والاستتناج.

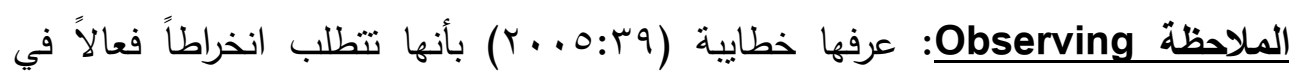
معالجة الأشياء واستخدام الحواس بشكل مباشر مع آلات بسيطة أو معقدة، وهذه العملية: - مف خصائص الأشياء.

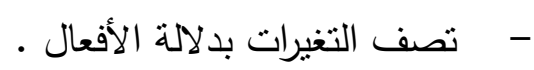
- - متف التغيرات بدقة بدلالة النماذج و علاقات.

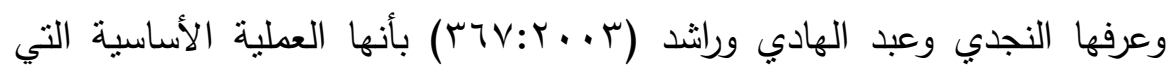

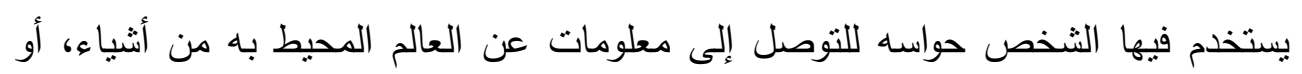
طواهر أو حوادث.

وتعرف الباحثة الملاحظة بأنها " العملية الأساسية التي يستخدم فيها الطفل جميع حواسه أو بعضها للتوصل إلى معلومات عن العالم المحيط، والظواهر العلمية". يتيح المحتوى الفرص للطقل للقيام بما يلي: - تحديد الأشياء والظواهر باستخدام الدواس. - تمبيز الخصائص الطبيعية للأشياء والأحداث بالملاحظة المباثدرة. - تسجيل الصفات المناسبة وغير المناسبة للأشياء والاحداث بالملاحظة المباشرة. - وصدف التغيرات الحادثة في الأشياء أو الظواهر في عبارات محدة بناء على الملاحظة المباشرة.

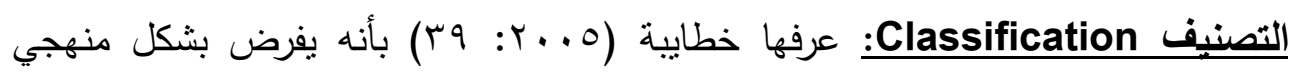
ترتيباً على المعلومات، قائماً على الملاحظة، وهذه العملية: - تؤدي لخلق مجموعات باستخدام صفة واحدة، وتعبر عن العلاقات الخطية. 
أ.م.د/ عبير صديق أمين

فاعلية برنامج قائم على استراتيجيات التطلم النشط

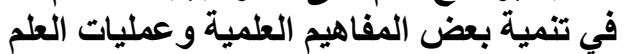
لاى طقل الروضة ضعيف السمع العية

- تؤدي لخلق مجموعات ومجموعات فرعية باستخدام صفة واحدة للتعبير عن

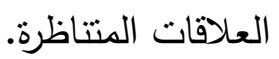

- تؤدي لخلق مجموعات باستخدام عدة صفات للتعبير عن العلاقات المتتاظرة بين المجموعات المختلفة.

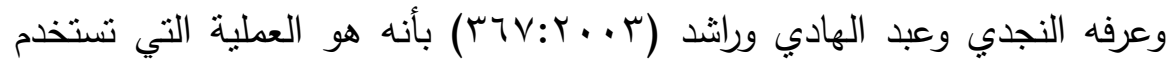
تقسيم الأثياء أو الأحداث إلى مجموعات، طبقاً لصفات معينة. وتعرف الباحثة التصنيف بأنه: العملية التي يقوم بها الطفل بتقسيم الأثنياء والأحداث إلى مجموعات طبقاً لصفات معينة. يتيح المحتوى الفرص للطقل للقيام بما يلي:

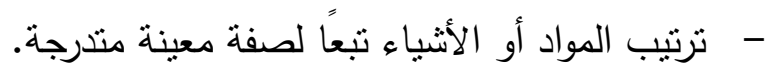

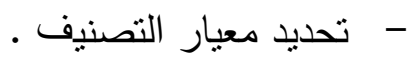

- مقارنة الأشياء والمواد تبعًا لأوجه الشبه والاختلاف فيما بينها. - مضع الأشياء في مجموعات على أساس خصائص مشتركة.

الاستتتاج Conclusion: عرفه سعيد والبلوشي (9 . .؟:^^) بأنه: يتم فيه الانتقال من العام إلى الخاص، ومن الكليات إلى الجزئيات، ويستخدم المتعلم ما يعرفه من معلومات لئن للوصول إلى استتناجات معينة.

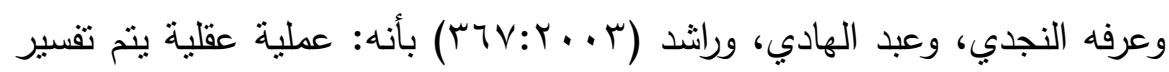
وتوضيح ملاحظاتتا، وغالباً ما يكون ذلك اعتماداً على خبراتتا السابقة. وتُعرف الباحثة الاستنتاج بأنه: هو العملية العقلية التي يتم فيها تفسير، وتوضيح

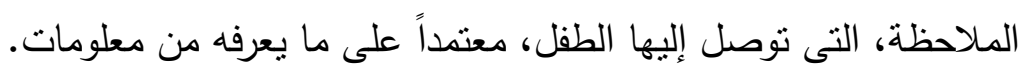
يتيح المحتوى الفرص للطقل للقيام بما يلي: - التوصل إلى تعميم من معلومات فرعية . - استخلاص معلومة أو معلومات فرعية جديدة من تعميم معروف . 
- - الربط بين ملاحظة أو معلومة متوافرة عن ظاهرة بمعلومة سابقة. - التوصل إلى معلومة فرعية جديدة من معلومة سابقة .

وكما سبق يتضح أن اكتساب طفل الروضة للمفاهيم العلمية وعمليات العلم سواء

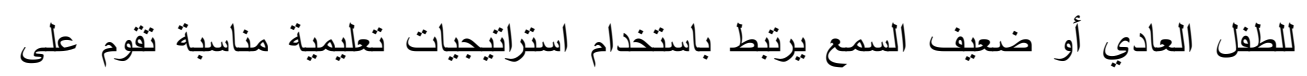

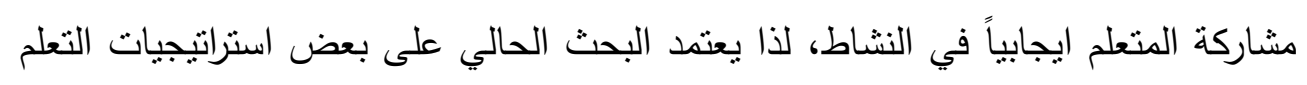
النشط لتحقيق هدف البحث.

\section{المحور الثالث: التعلم النشط.}

\section{مفهوم التعلم النشط : n}

يعد مصطلح التعلم النشط من المصطلحات التربوية التى ورد فيها العديد من التعريفات، والتى اتفقت جميها فى جوهرها ونظرتها الحقيقية الى اهمية هذا النمط من التعلم، و تعود

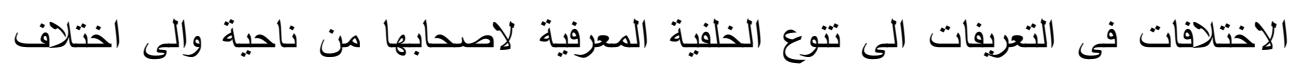

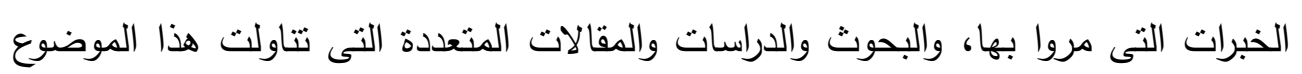
فى عصر يتصف بالانفجار المعرفي من ناحية اخرى، وفيمايلي نستعرض بعضا من هذه وله التعريفات:

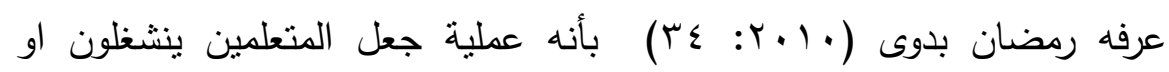
ينخرطون فى بعض الانشطة التى تدفعهم نحو التفكير فيما يتعلمونه، وكيف يوظفون هذه بـانه

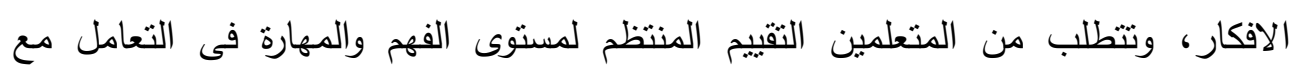
المفاهيم والمشكلات فى تخصص معين، وبلوغ المعرفة عن طريق المساهمة او المشاركة،

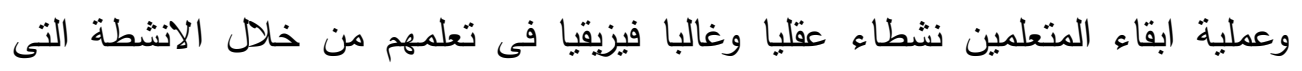
تشركهم فى جميع المعلومات والتقكير وحل المشكلة.

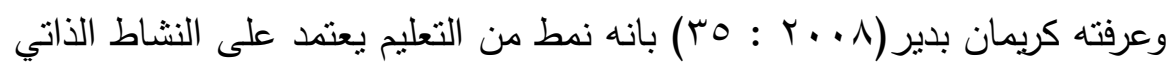
والمشاركة الايجابية للمتعلم والتى يقوم من خلالها بالبحث باستخدام مجموعة من الانشطة

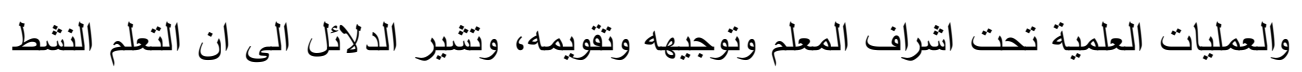


يجعل المتعلمين مستمتعين بالتعلم، وتتكون لديهم القدرة على اكتساب المهارات والمعارف مما يحول العملية التعليمية الى شراكة ممتعة بين المعلم والمتعلم.

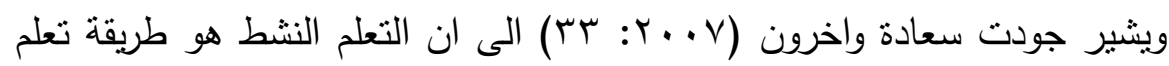
وتعليم فى ان واحد، يشترك فيها الطلبة بانتطة متتوعة تسمح لهم بالاصغاء الايجابي

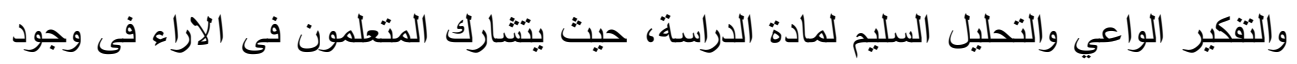
المعلم الميسر لعملية التعلم مما يدفعهم نحو تحقيق أهداف التعلم. وفى تعريف لورينزين ميشيل (24-Lorenzen,M,2006:19) ذكر بأن التعلم النشط عبارة عن طريقة تعلم تسمح للمتعلمين بالمشاركة الفاعلة فى الانشطة داخل الحجرة

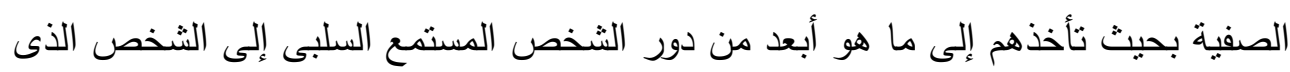

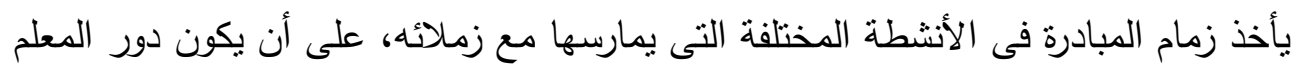

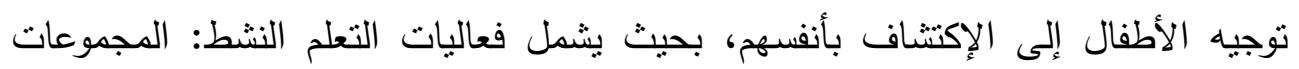

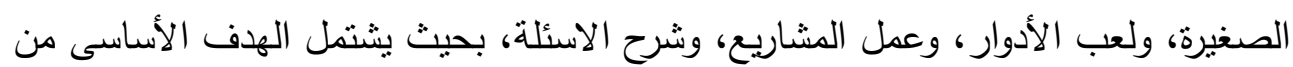

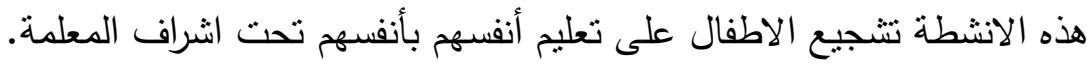
وعرفته حامد (0 . . ץ: 7 (1) بأنه التعلم القائم على الانشطة المختلفة التى يمارسها المتعلم، والتى ينتج عنها سلوكيات تعتمد على مشاركة المتعلم الفعالة والايجابية.

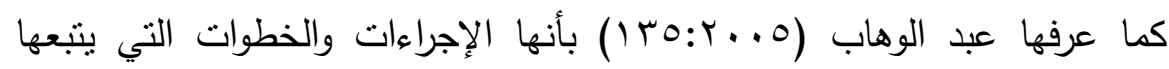
المتعلم، والمخطط لها مسبقاً، والتي تتطلب منها التفكير والقراءة والكتابة والتحدث والمناقتشة، وبالتالي فإن استراتيجيات التعلم النشط تقوم على المرتكزات التالية: - - نشاط المتعلم و ايجابياته أثناء العملية التعليمية التعلمية. - تقاعل المتعلم مع المادة التعليمية بشكل إيجابي مخطط له وهادف. - - بذل المتعلم للجهد العقلي و اليدوي لبناء المعرفة في ذهنه.

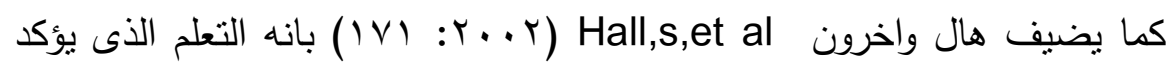
على المشاركة النشطة للمتعلمين فى عملية تعلمهم. 
ومما سبق يتضح انه على الرغم من تعدد التعريفات والمفاهيم لمصطلح التعلم

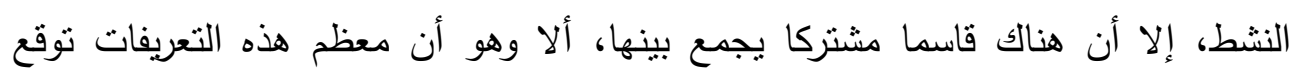

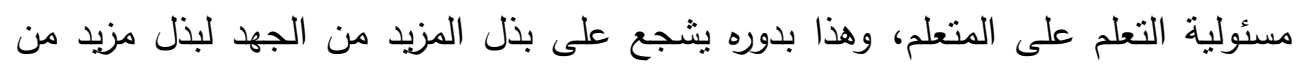

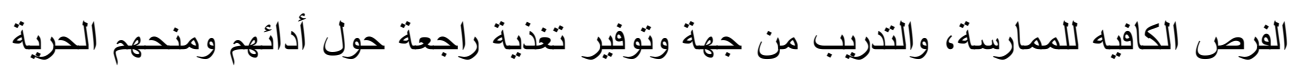

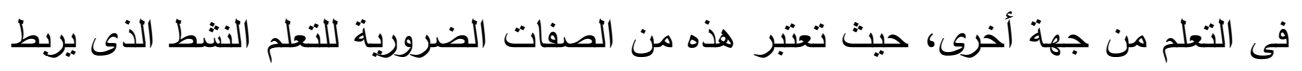

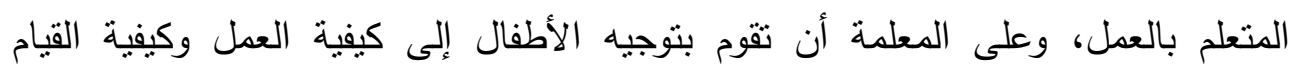
بالمهمة، وإدارة النشاط بحيث يتم توزيع المسئولية بين الأطفال والمعلمة.

ومن خلال ما سبق يمكن تعريف التعلم النشط بأنه : " كل ما يقوم به المتعلم من جهد عقلي أو بدني، ويبذل فيه جزءا من طاقته، ويكون مخططا له من قبل المعلم فى سبيل

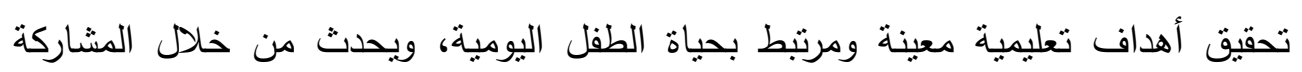

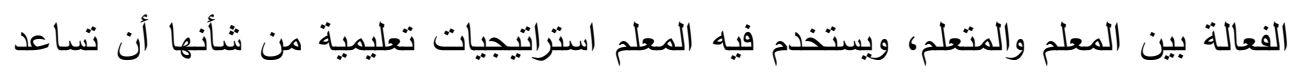
المتعلم على ممارسة الأنشطة من خلال مشاركته الإيجابية فى الموقف التعليمي التعلمي" . أسس التعلم النشط: يعتمد التعلم النشط على عدة أسس منها: - اشتراك المتعلمين فى اختيار نظام العمل وقواعده. - اشتراك المتعلمين فى تحديد أهدافهم التعليمية. - تتوع مصادر التعلم. - استخدام استراتيجيات التدريس المتمركزة حول المتعلم والتى تتتاسب مع قدراته،

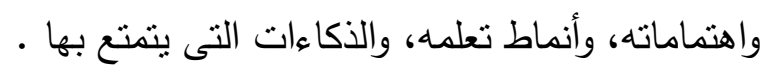
- اشناعة جو من الطمانينة والمرح والمتعة أثثاء التعلم . - مساعدة المتعلم فى فهم ذاته، وإكتشاف نواحى القوة والضعف لديه. - الاعتماد على تقويم المتعلمين انفسهم وزملائهم - السماح للمتعلمين بالادارة الذاتية . 
أ.م.د/ عبير صديق أمين

فاعلية برنامج قائم على استراتيجيات التطلم النشط

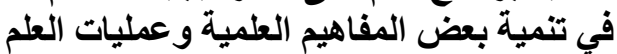

لاى طقل الروضة ضعيف السمع لئح

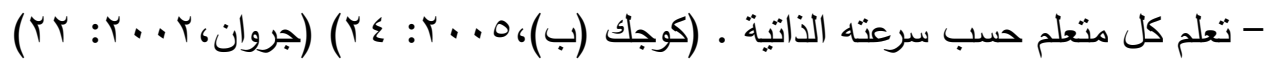

خصائص التعلم النشط : يتميز التعلم النشط بعدة خصائص منها :

- التعلم النشط ذو معنى،أى أنه تعلم يرتبط بحاجات المتعلم الجسمية والعقلية

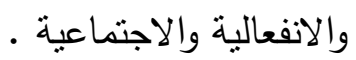

- تعلم قائم على الخبرة المباشرة الحقيقية، وكلما كانت الخبرة أقرب إلى الواقع كلما كان التعلم أكثر فاعلية وبقاء ـ التعل

- هو تعلم يتتاسب مع قدرات الفرد وامكاناته، ويسمح للمتعلم السير فى التعلم حسب سرعته الذاتية .

- هو التعلم الذى يثير دافعية المتعلم نحو التعلم، ويهئ له النجاح، لذلك فإنه يبعث فى نفسه حب التعلم والإكتثاف والبحث عن طرق جديدة للحل والتعلم .

- يهدف إلى تحقيق النمو الثامل والمتكامل لدى المتعلم.

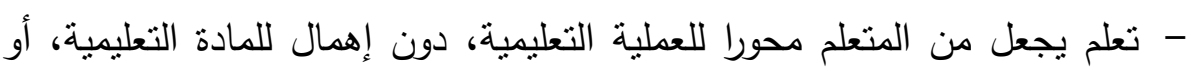

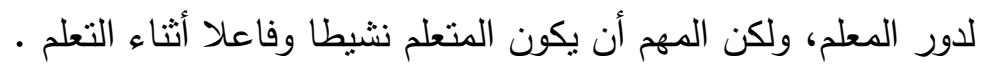

- يتضمن معلومات ومهارات وإتجاهات وقيم قابلة للبقاء، ويمكن للمتعلم الاحتفاظ

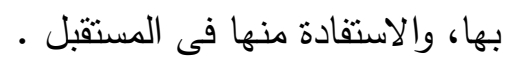

- ينمى قدرة المتعمين على حل المشكلة وأداء المهام المطلوبة منهم بصورة أفضل .

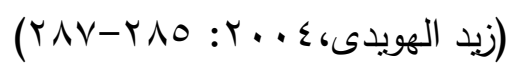

أهداف التعلم النشط : تتمثل اهداف التعلم النشط فيما يلى :

- تشجيع المتعلمين لإكتساب مهارات التفكير المختلفة .

- التتويع فى الأنشطة التعليمية الملائمة للمتعلمين، لتحقيق الأهداف التربوية المنشودة . - دعم الثقة بالنفس لدى المتعلمين نحو ميادين المعرفة المنتوعة. - تشجيع المتعلمين على طرح الأسئلة المختلفة. 
- تشجيع المتعلمين على حل المشكلات.

- قياس قدرة المتعلمين على بناء الأفكار الجديدة وتتظيمها. - تشجيع المتعلمين وتدربيهم على أن بعلموا أنفسهم بأنفسهم. - تطوير دافعية داخلية لدى المتعلمين لحفزهم على التعلم. - تشجيع المتعلمين على المشاركة فى وضع أهداف تعلمهم، والسعى نحو تحقيقها. - تمكين المتعلمين من من اكتساب مهارات التعاون والتفاعل والتواصل مع الاخرين. - زيادة الأعمال الابداعية لدى المتعلمين وتمكينهم من العمل الجماعى.

- تسهيل التعلم من خلال مرور المتعلمين بخبرات عملية مرتبطة بمشكلات حقيقية.

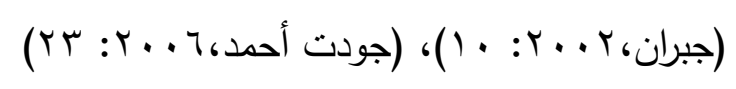

وقد قامت عدة دراسات في مجال توظيف استراتيجيات التعلم النشط في مرحلة

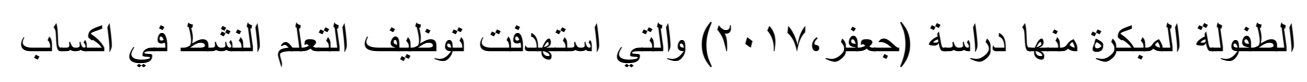

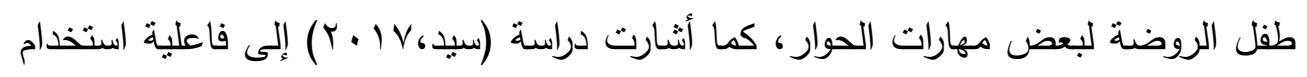
استراتيجيات التعلم النشط في تتمية بعض القدرات الابتكارية لدى طفل الروضة، ودراسة

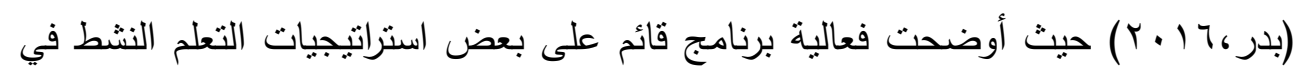

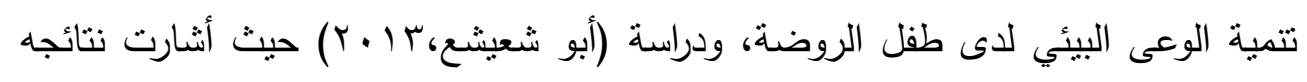
إلى فاعلية الدراما التفاعلية في تتمية بعض لإئية لمهارات الحياتية لدى أطفال ما قبل المدرسة. كما أنشارت الدراسات والبحوث إلى فاعلية استراتيجيات التعلم النشط في تتمية المفاهيم العلمية، منها دراسة (مسلم، Y. V.) حيث أثنارت نتائجها إلى فاعلية خرائط التفكير

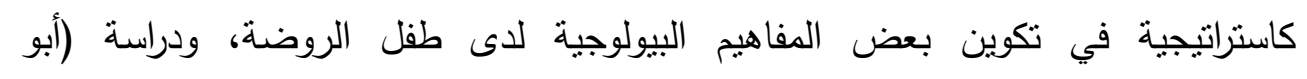

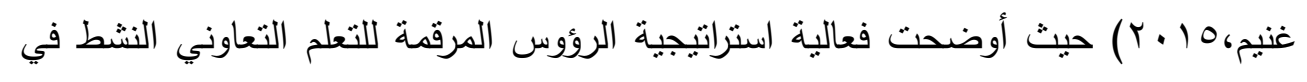
تتمية بعض مفاهيم علوم الحياة لدى طفل الروضة، كما أثنارت دراسة (الدويني، • ( • ب)

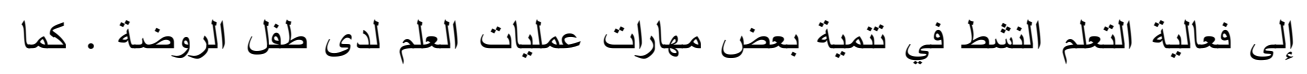


أوضحت دراسة (Ornit S., Levy ,Y \&Zemira M, 2011) إلى أهمية مشاركة الطفل ودوره الإيجابي في اكتساب المفاهيم العلمية بصفة عامة .

استراتيجيات التعلم النشط:

وتُعرف استراتيجيات التعلم النشط بأنها " كل الاساليب التى تتطلب من المتعلم القيام بممارسة بعض المهام فى الموقف التعليمى أكثر من مجرد الإستماع إلى محاضرة للمعلم، وتتمثل عناصر التعلم النشط فى ممارسة المتعلم للتحدث، والإستماع والقراءة والكتابة، وإلقاء الأسئلة، والحركة، والتفاعل مع عناصر الموقف التعليمى الاخرى وإصدار ردود الفعل المناسبة فى الموقف التعليمى • (Mckinny,2001)

وبذلك يمكننا تعريف استراتيجيات التعلم النشط اجرائياً في البحث الحالي بأنها: "كل الأساليب التي تتطلب من طفل الروضة ضعيف السمع المشاركة بصورة إيجابية في

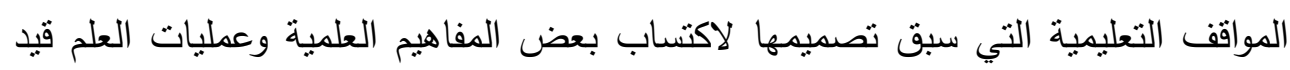
البحث تحت اشراف وتوجيه المعلمة" .

ومن هنا سوف يعتمد البحث الحالى على بعض استراتيجيات التعلم النشط وهى كالاتى : التعلم التعاونى - التعلم بالاكتشاف - الالعاب التعليمية .

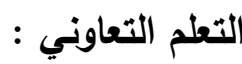
يُعرف التعلم التعاونى بأنه: أسلوب تعليمي يقوم على تتظيم الصف، حيث يقسم

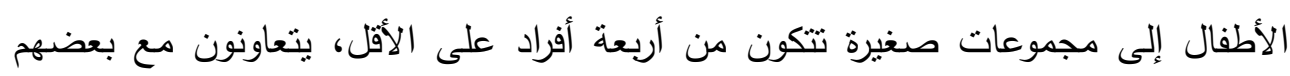

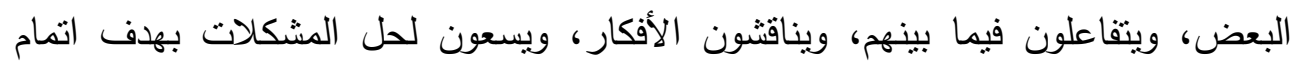
الهدف المكلفين بها، ويكون كل طفل في المجموعة مسئولاً عن تعلم زملائه، وعن نجاح

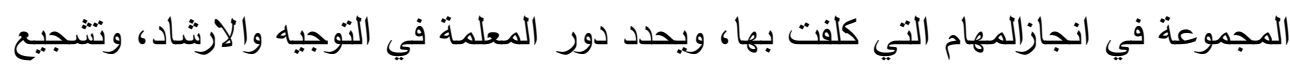

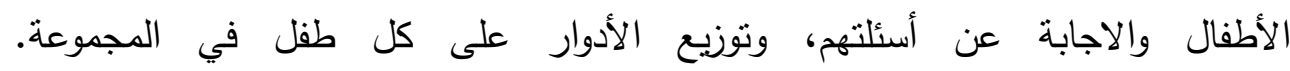

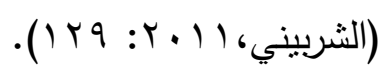




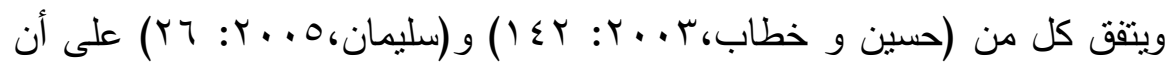
التعلم التعاوني "استراتيجية تدريس خاصة بالفصل، حيث أنها تسهل التعلم وفهم المشكلات،

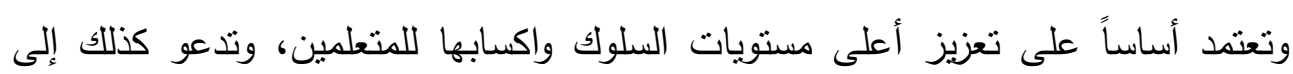

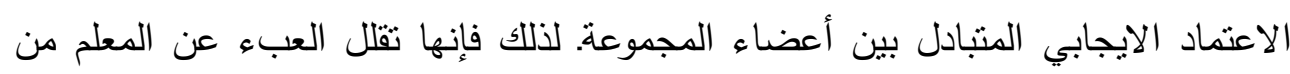
حيث مسئوليته الكاملة عن عملية التدريس، فيتحدد دوره في مراقبة وتوجيه وارشاد وتقويم

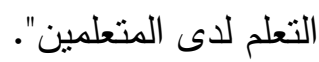

ويمكن تعريف استراتيجية التعلم التعاوني اجرائياً بأنه: "طريقة تعلم تقوم على تتظيم أنشطة علمية تعليمية، ينم فيها تقسيم الأطفال إلى مجموعات صغيرة، تتكون كل منها من

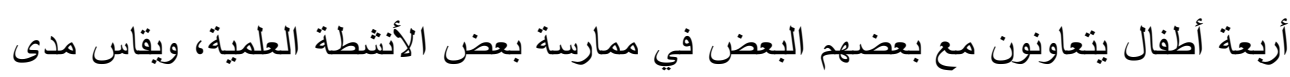

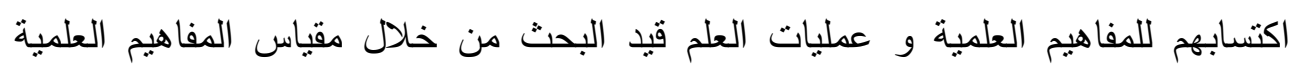
المصور ، ومقياس عمليات العلم المقترح".

\section{العناصر الأساسبة للتعلم التعاوني:}

التعلم التعاوني يعتمد بشكل أساسي على مشاركة المتعلمين وبصورة ايجابية في النشاط رغم افتقاد البعض منهم للمهارات الضرورية لتحقيق نواتج التعلم باستخدام استراتيية التعلم التعاونى، لذا من الاهتمام بالعناصر التالية حتى تتحقق أهداف تلاك الاستراتيدجية: 1. الاعتماد الإيجابي المتبادل بين أفراد المجموعات، حيث يتعرف كل طفل على دوره بشكل محدد في النشاط وأهمية دوره في الإنجاز الجماعي، فيتم التعاون فيما بينهم لانجاز المهام المطلوبة وكما أنشار الحيلة (1.... ب:

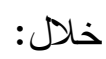

- تحديد أهداف مشتركة تسعى أفراد المجموعة لتحقيها، ويعتمد نجاحها على إنجاز كل طفل لدوره.

- التعزيز بشكل جماعي ويتم حينما تحصل المجموعة على مكافاة واحدة جماعية عند تحقيق الأهداف. 
أ.م.د/ عبير صديق أمين

فاعلية برنامج قائم على استراتيجيات التعلم النشط

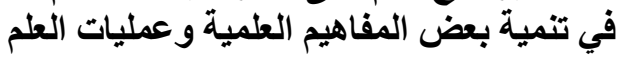

لاى طقل الروضة ضعيف السمع لئة

- استخدام أطفال المجموعة الواحدة مصارد التعلم معً منل أدوات وخامات

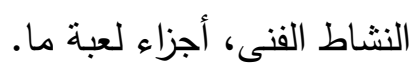

- تقسيم العمل ويتم بتقسيم النشاط إلى مجموعة من المهمات الفرعية ويتم توزيعها على الأطفال وعلى كل منهم أداء المهية حسب قدراته.

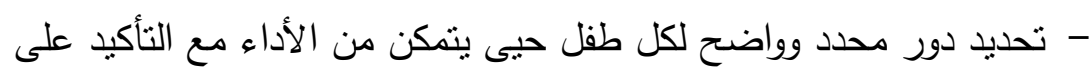

$$
\text { عدم سيطرة أحد على جميع الأدوار . }
$$

r. المحاسبية الفردية .فكل عضو في المجموعة مطالب أن يبذل جهاً فردياً في التعلم حتى يتقن المطلوب منه تعلمه، فنجاح المجموعة في التعلم لا يغني عن نجاح

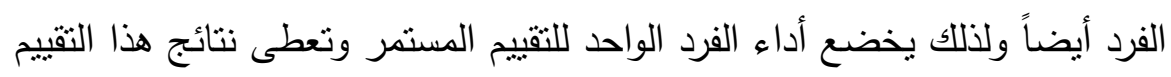

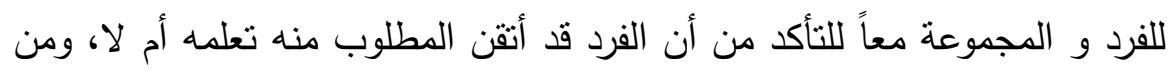

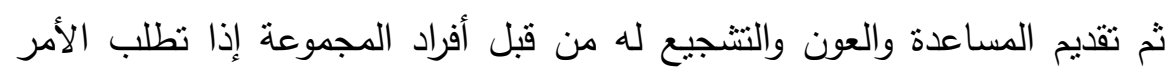

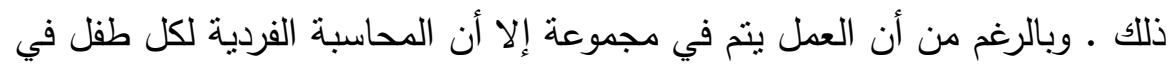
المجموعة هى الدليل على مساهمته في تحقيق أهداف الجماعة، وذلك من خلال الدور الذي يقوم به كل طفل بشرط تبادل هذه الأدوار بهدف التكامل والتتسيق

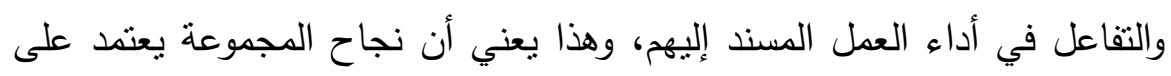

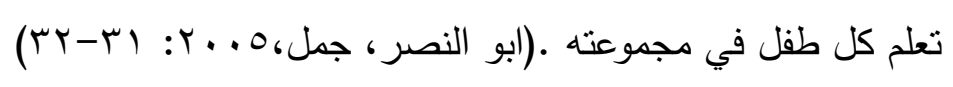

r. التقاعل وجةً لوجه ـ فأساس التعلم التعاوني هو التقاء أعضاء المجموعة وجهاً لوجه

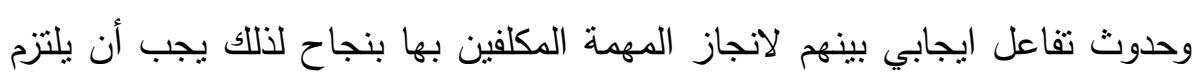

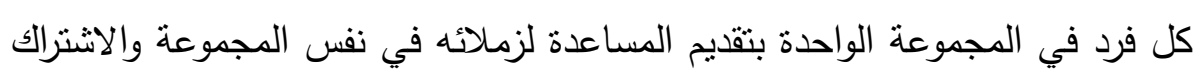

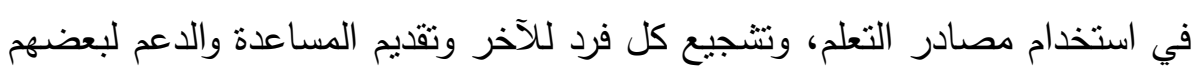
البعض لتحقيق الهدف المشترك، ويتم ذلك من خلال تتظيم جلسة الأطفال والكراسي

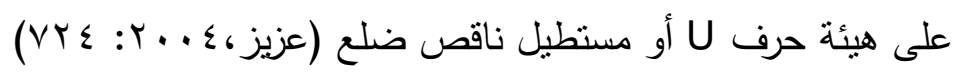

؛. مهارات العمل الجماعي . فتتفيذ النشاط التعاوني يتطلب تدريباً للأطفال على

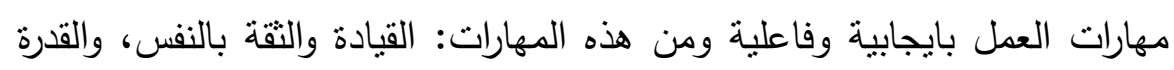


على التعامل مع الاختلاف، القدرة على التفاهم والاتصال، تقدير العمل التعاوني والبعد عن الذاتية، واحترام الرأى و الرأى الآخر .

ه. عمليات المجموعة ـ وهى عملية تقييم ذاني من قبل أعضاء المجموعة لأدائهم في

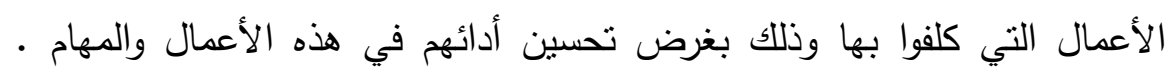

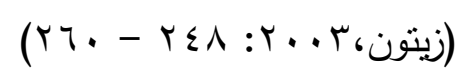

هذا وقد راعت الباحثة العناصر السابقة في تخطيط وتتفيذ الأنشطة من خلال توضيح دور كل طفل وأهميته في الأداء الجماعي، مناسبة جلسة الأطفال لاستراتيجية التعلم

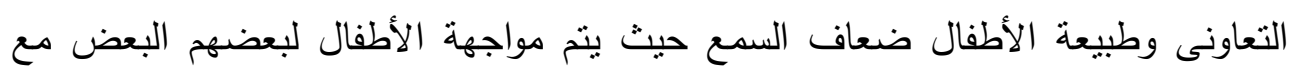

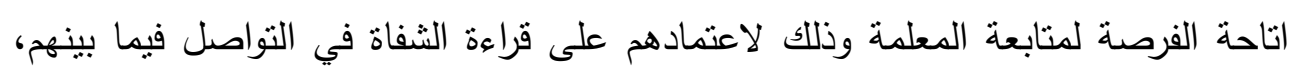
والتقييم المستمر المصاحب / التكويني للأداء الفردي و الجماعي على حد سواء.

أهمبة التعلم التعاوني لطفل الروضة:

أثنارت نتائج الدراسات فاعلية توظيف استراتيجية التعلم التعاوني في تتمية مهارات

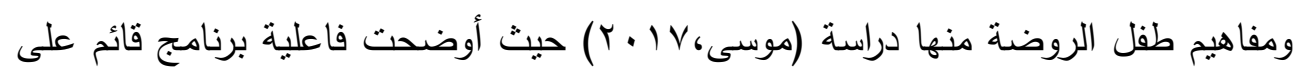

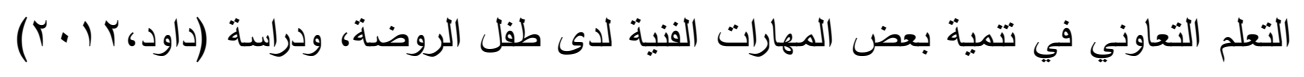

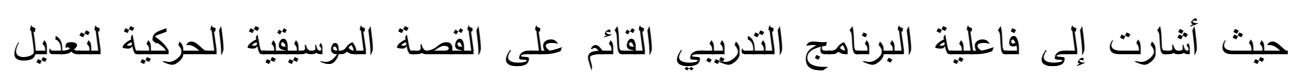
بعض سلوكيات الطفل المشكل في رياض الأطفال في ضوء استراتيجيات التعلم التعاونى. لذا يعتمد البحث الحالي على استخدام التعلم التعاوني كأحد استراتيجيات التعلم

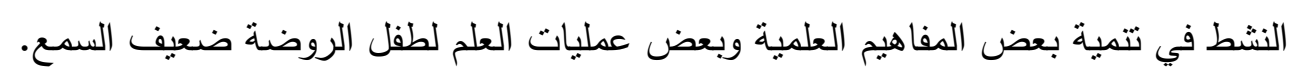

\section{شروط التعلم التعاونحى:}

مما سبق يتضح أن التعلم التعاوني لا يتم إلا فى وجود مجموعة من العناصر والثشروط وهى:

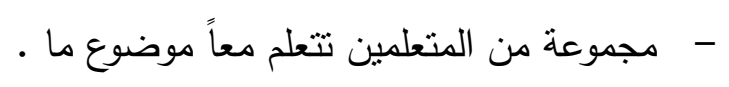
- - هدف مشترك يجتمع مجموعة المتعلمين عليه وهو اكتساب العديد من

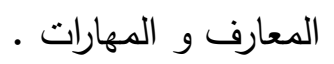




$$
\text { - - العلاقات الايجابية بين أفراد المجموعة . - العمل و النشاط الايجابي على المستويين الفردي و الجماعي • }
$$

- - عدد المجموعة لايتعدى (0) وفي حالة ضعاف السمع يفضل ألا يتعدى (ع) -

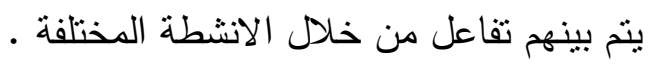

وقد راعت الباحثة شروط التعلم التعاوني فى تصميم و تتفيذ الأنشطة من حيث عدد المجموعة كان (ع) أو (r) مع تشجيع الأطفال على المشاركة في الانشطة وتوضيح

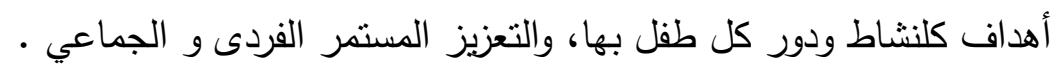

\section{التعلم بالاكتشاف : الت}

وتُعرف استراتيجية التعلم بالاكتشاف بأنها: أسلوب تعليمي يقوم على مواجهة

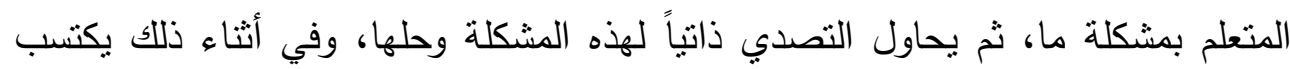

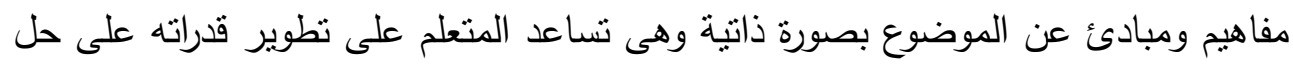

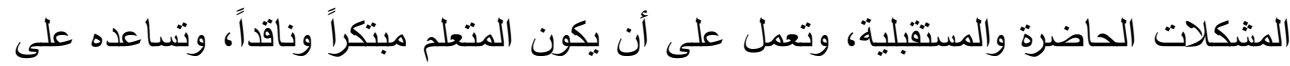
التفكير المنظم، وهي تسهم في تدعبم مبدأ التعلم الذاتي من خلال الجهود الذاتية التي يقوم

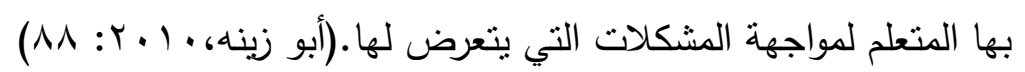
وتعرف استراتيجية التعلم بالاكتشاف اجرائياً بأنه : " طريقة تعلم تقوم على مواجهة

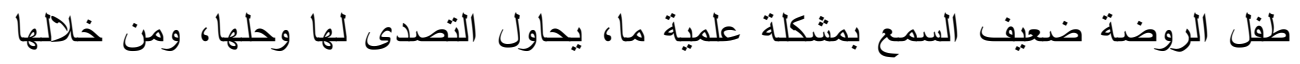
يكتسب بعض المفاهيم العلمية وعمليات العلم من خلال خطوات علمية منظمة".

\section{أهمبة الاكتثاف لطقل الروضة:}

ان التعلم بالاكتشاف له مميزاته التي تدعو لاستخدامه كطريقة للتعلم، حيث أن أسلوبه يجمع بين الدراسة النظرية و الدراسة العملية والذي يؤدى بدوره إلى احتفاظ المتعلم

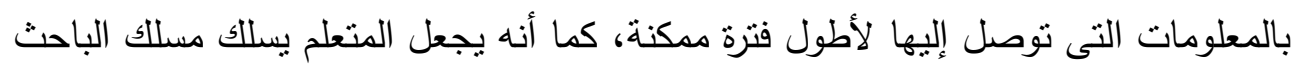
لا المستقبل للمعلومات مما ينمي لديه قدراته العقلية والذهنيبة. 


\section{المجلة العلمية لكلية رياض الاطفال - جامعة اسيوط}

وكما أثنار "برونر" إلى أن التعلم بالاكتثاف يزيد من الكفاءة الذهنية لأن المتعلم

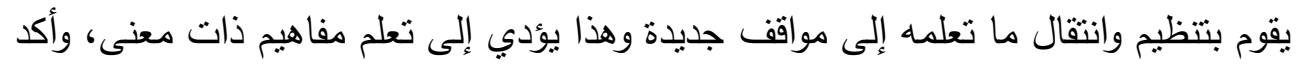
على الدوافع الداخلية ففي مواقف الاكتثاف يشعر يشعر الكتعلم بالانجاز والنجاح والثقة

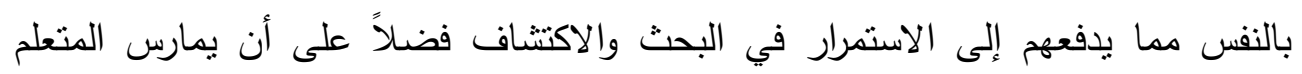
عمليات الاستقصاء والاستفسار العلمى كما في الملاحظة و القياس والتفسير والاستدلال والتجريب، كما أن التعلم بالاكتثاف يساعد على بقاء أثز التعلم، فالمعلومات التي يتوصل

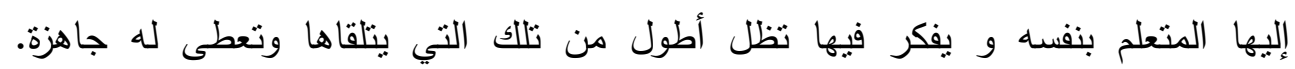

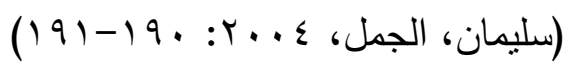

كما أنشارت البحوث والدرسات إلى فاعلية استراتيجية الاكتثاف في تتمية بعض

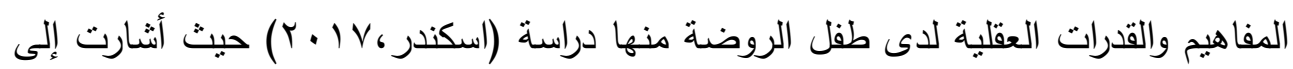
فاعلية استراتيجيتي لعب الدور والاكتثاف في تتمية الذكاء الطبيعي لدى طفل الروضة، كما

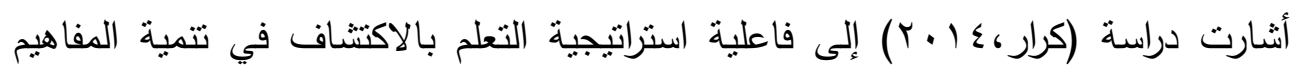

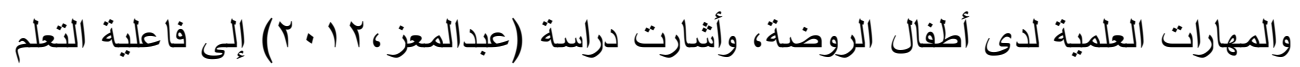
باللعب والاكتشاف في تتمية بعض عمليات العلم الأساسية لاى طفل الروضة، كما

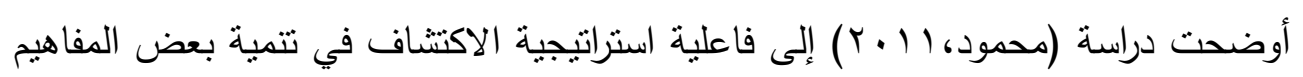
والتفكير الاستقرائي لدى أطفال ما قبل المدرسة.

\section{محدات استراتيحية الاكتشاف:}

يتم استخدام استراتيجية الاكتشاف في ضوء مجموعة من العناصر وهى: - أهداف محددة واضحة لاى كل من المعلمة والطفل. - مجموعة من الأسئلة المثيرة للتفكبر والتز ترتبط بموضوع الخبرة او النشاط. - مصادر تعليمية وتقنيات تربوية مساعدة للتوصل لتحقيق الأهداف. - معلمة موجهة وقائدة للتعلم تتجنب تقديم المعارف و الخبرات بصورة تقليدية. - مجموعة من المتعلمين المشاركين بايجابية في النشاط. 


$$
\text { - - - التعزيز المستمر لأداء الأطفال. }
$$

- الإنجاز يرتبط دائما بانجاز كل طفل بالنسبة لقدراته.

وقد حرصت الباحثة على مراعاة عناصر ومحددات استخدام استراتيجية الاكتثاف من خلال وضوح الأهداف وتتظيم البيئة والمصادر التعليمية بما بياعد الأطفال على ملى

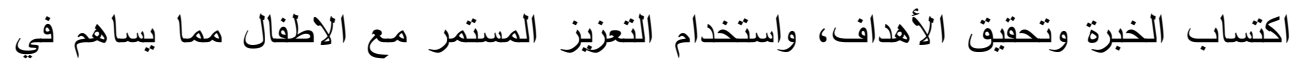
تحقيق الاهداف.

لذا يعتمد البحث الحالي على استخدام الاكتثاف في تتمية بعض المفاهيم العلمية وبعض عمليات العلم لطفل الروضة ضعيف السمع.

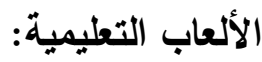

تُعد الألعاب التعليمية من أهم الوسائل التعليمية التي يمكن أن تجسد المفاهيم

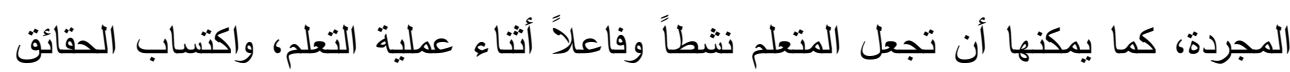
والمفا هيم.

وتُعرف استراتيجية الألعاب التعليمية بأنها: نشاط تعليمي منظم، ويتم بين اثثان أو أو

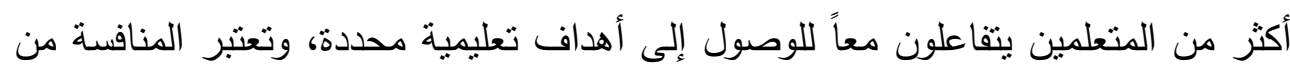
عوامل التفاعل بينهما، ويتم تحت اشراف وتوجيه المعلم الذي يقوم بدور المرشد أو المنسق، ويقدم لهم المساعدة عندما ينطلب الموقف ذلك، ويخصص جزء بعد انتهاء اللعبة للمناقتنة

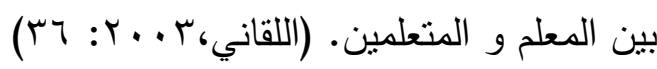

\section{وظائف اللعب:}

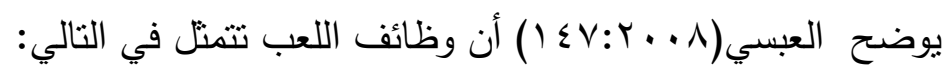
- تزويد المتعلم بخبرات أقرب للواقع العملي من أي وسيلة أخرى. - الكثف عن بعض الجوانب الحياتية الهامة للمتعلم. 
- زيادة دافعية الطلبة للتعلم، من خلال القيام بأدوار حقيقية لمعالجة مشكلات حقيقية قد تحدث لهم في المستقبل. - اشباع ميول الأطفال وتلبية حاجاتهم والمساعدة في احداث التوازن لديهم. - - استخدام اللعبة كوسيلة اجتماعية لتعليم الأطفال قواعد السلوك وأساليب التواصل والتكيف وتمنت القيم الاجتماعية.

- استخدام اللعبة كوسيلة للكثف عن شخصية الطفل وامكاناته النفسية والعقلية. - استخدام اللعبة كوسيلة فاعلة في تخليص الأطفال من الأنانية والتمركز حول الذات.

\section{عناصر اللعبة:}

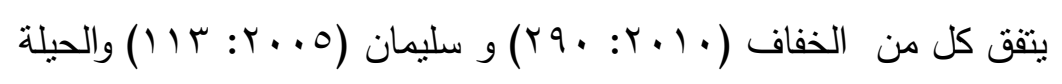

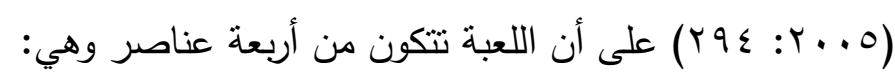

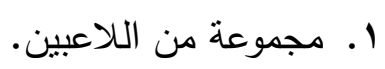
r. أنظمة وقوانين تحكم اللعبة.

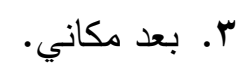
ع. بعد زماني وهو الزمن المحدد للعبة.

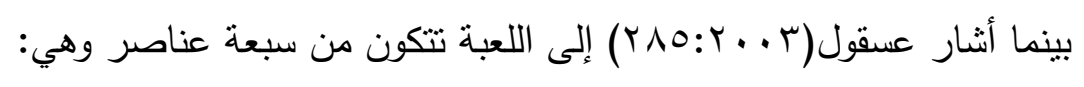
ا ـ الأهداف التعليمية: الخاصة بكل لعبة .

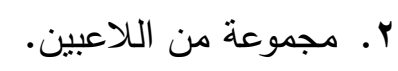
r. أنشطة وقوانين: تحددها المعلمة و يحفظها الأطفال. ؛. عنصر الزمن: وهو الوقت الذي تستغرقه اللعبة. هـ المكان: مجموعة الظروف التي يتم فيها اللعبة. 
7 . النشاط التتافسي: وتعبر عن حركة المتتافسين أثناء اللعبة. V. النتيجة: وتشكل خاتمة اللعبة، والتي يتحدد فيها الفائز والخاسر . وقد راعت الباحثة المكونات الأساسية للعبة التعليمية بما يتناسب مع طبيعة واحتياجات طفل الروضة ضعيف السمع بما يساهم تحقيق أهداف البرنامج المقترح شروط اللعبة :

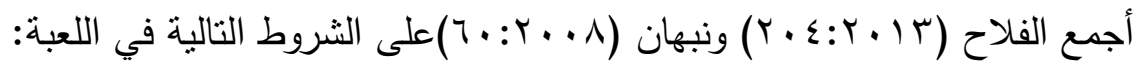
1. اختبار الألعاب التي لها أهداف تربوية محددة وفي نفس الوقت مثيرة وممتعة. r. أن تكون قواعد اللعبة سهلة وواضحة وغير معقدة. r. أن تكون اللعبة مناسبة لخبرات وقدرات وميول الأطفال. ؛. أن يكون دور الطفل واضحاً ومحدداً في اللعبة. ه. أن تكون اللعبة من بيئة الطفل. 7. أن يشعر الطفل بالحرية والاستقلالية في اللعب.

وقد راعت الباحثة شروط اللعبة بما يتتاسب وطبيعة أطفال العينة من أطفال الروضة ضعاف السمع من جانب، وبما يساهم في تحقيق أهداف البرنامج. أهمبة الألعاب التعليمية :

أثنار العلماء إلى أهمية الألعاب ودورها في نتمية شخصية الطفل مما جعل الألعاب التعليمية محور العديد من الدراسات التى أكدت الدور التربوى لتلك الألعاب منها دراسة (Hannkainen , M ., Singer , E., Oers,B , 2013) التى استهدفت مقارنة بين استخدام اللعب مقابل التعليم المباشر في اكساب الطفل لمفاهيم العلوم إلى تميز أسلوب واستراتيجية اللعب في نتمية المفاهيم لطفل الروضة حيث أنه من خلال اللعب لا يتضمن فقط مشاركة الأطفال الفعالة في العديد من التدريب العملي على الأنشطة المتعلقة بالمفهوم

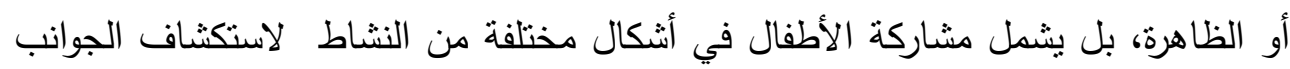




\section{المجلة العلمية لكلية رياض الاطفال - جامعة اسيوط}

المختلفة لمفهوم / الظواهر. ومن بين المفاهيم العلمية التي تضمنها البحث: الألوان، الكائنات الحية / غير الحية، والجاذبية، والمغناطبس، ووجود الهواء والظواهر ذات الصلة لهنة لهنه بالهواء، الطفو والغوص، ومراحل الماء.

كما أنثارت نتائج دراسة (الحفافي، 10 • ب) إلى فعالية الألعاب التعليمية الالكترونية

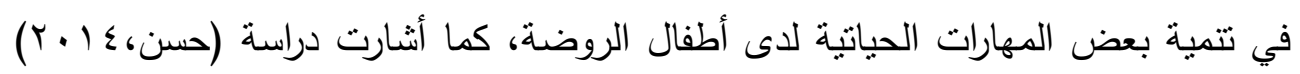
إلى فاعلية برنامج قائم على استخدام الألعاب العلمية التعليمية في ضوء العية المعايير القومية في اكتساب المفاهيم العلمية وتتمية بعض مهارات عمليات العلم الأساسية والتفكير الابتكاري

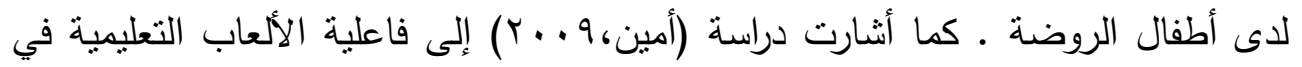

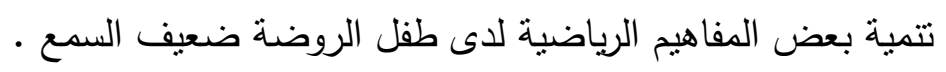
لذا يعتمد البحث الحالي على استخدام الألعاب التعليمية في تتمية بعض المفاهيم

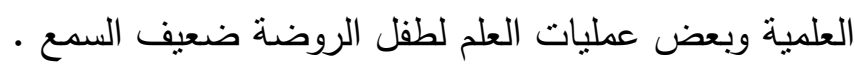
ارشادات استخدام استراتيجيات التعلم النشط :

هناك مجموعة من الارشادات التى تجمع استراتيجيات التعلم النشط سواء التي يعتمد عليها

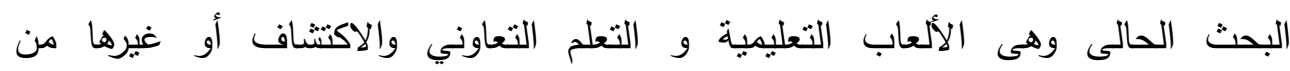
الاستراتيجيات والتي يجب مراعاتها حتى تساهم في تحقيق أهداف النشاط وهي:

- دور الطفل الايجابي في النشاط، بحيث يكون الطفل نشط وفاعل وباحث عن الخبرة . - - دور المعلمة الايجابي والذي يتمنل في التوجيه و الارشاد للعملية التعليمية. - وضح الأهداف سواء للمعلمة أو الطفل على حد سواء. - تتظيم البيئة التعليمية بما يتتاسب مع الاستراتيجية وطبيعة واحتياجات الطفل. - التعزيز المستمر لأداء الطفل على المستوى الفردي والجماعي. - التقييم المستمر بمراحله الثلاث : قبلي - تكويني - بعدي. 
نعرض فيما يلي الإجراءات التي اتبعت في البحث الحالي من العينة والأدوات المستخدمة، ووصف لإجراءات البحث يتضمن التطبيق العملي والمعالجات الإحصائية. 1- منهج البحث: استخدم البحث الحالي المنهج التجريبي (التصميم شبه التجريبي (Experimental Method المجموعتين: التجريبية والضابطة، وبإتباع القياسين القبلي والبعدي لأفراد المجموعتين.

Y - عينة البحث : تم اختيار عينة البحث من أطفال امركز الصم وضعاف السمع

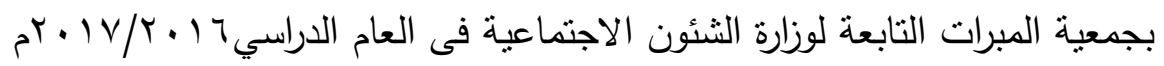

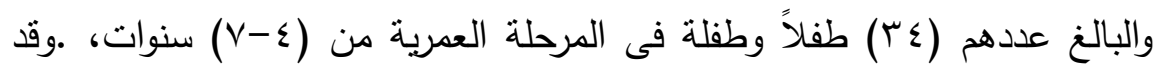
روعي عند اختيار العينة أن تحقق المواصفات الأساسية الآتية:

$$
\begin{aligned}
& \text { - يتراوح العمر الزمنى بين (ع-7) سنوات. }
\end{aligned}
$$

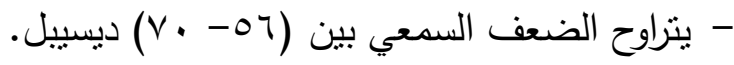

- الخلو من الشكلات الصحية الواضحة التي قد تئثر على أداء الأطفال

$$
\text { في البرنامج. }
$$

- الإلتزام فى الحضور للمركز وبالتالى برنامج الأنشطة التعليمية المقترح.

وقد بلغ عدد الأطفال الذين ينطبق عليهم الثروط سالفة الذكر (·r) طفلاً وطفلة

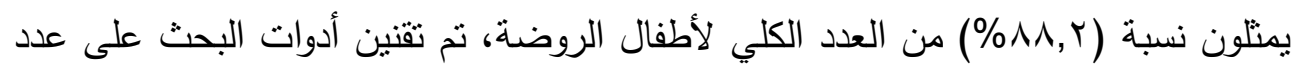

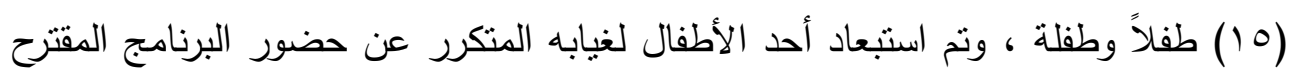

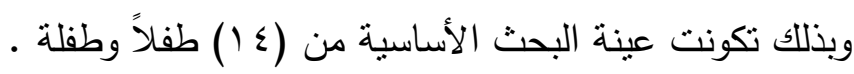

وقامت الباحثة بحساب معامل الإلتواء للتأكد من تجانس أفراد العينة على متغيرات البحث قبل تتفيذ الدراسة الميدانية، كما يوضحها الجدول التالي: 
المجلة العلمية لكلية رياض الاطفال - جامعة اسيوط

جدول ( 1): التجانس بين أفراد المجموعتين التجريبية و الضابطة (ن= ؛ 1)

\begin{tabular}{|c|c|c|c|c|c|}
\hline الالتواء & التباين & الانحراف & الوسيط & المتوسط & المتغيرات \\
\hline$\cdot, \varepsilon q \mu$ & $9,1 \vee$. & $r, \cdot r \wedge$ & $7 \varepsilon, \ldots$ & $7 r, 7 \leq r$ & السن \\
\hline - ,vqr & $0,1 \wedge V$ & $r, r V V$ & $99,0 \ldots$ & $৭ ৭, \leqslant \nvdash \wedge$ & الأكاء \\
\hline$\cdot, r \leq$. & $r,|\wedge|$ & $1, \leqslant \vee 7$ & $70, \ldots$ & $70, Y) \leq$ & الاعاقة السمعية \\
\hline $1,0 \cdot v$ & س & 1,17 & $1 \varepsilon, \ldots$ & $|r, \Delta V|$ & المفاهيم العلمية \\
\hline$\cdot, 11 r$ & $7,0 \times 1$ & r,or & $r \leq, 0 \ldots$ & $r \varepsilon, \varepsilon \wedge$ & عمليات العلم \\
\hline
\end{tabular}

يتضح من الجدول السابق أن قيمة معامل الالتواء تراوحت ما بين (-ب،+r) مما يشير إلى تجانس أفراد العينة في السن والذكاء ودرجة الاعاقة السمعية، والمفاهيم العلمية، لئل عمليات العلم.

كما تم إيجاد التكافؤ بين أطفال العينة (المجموعة التجريبية، المجموعة الضابطة) على كل من العمر الزمني، الذكاء، ودرجة الإعاقة السمعية، ومقياس المفاهيم العلمية، ومقياس عمليات العلم.

جدول (ץ): تكافؤ أطفال المجموعة التجريبية وإلمجموعة الضابطة في كل من العمر الزمني، والذكاء، ودرجة الاعاقة السمعية، و المفاهيم العلمية،وعمليات العلم باستخدام اختبار ويتنى (U Test) (حيث ن= \& 1 ( )

\begin{tabular}{|c|c|c|c|c|c|}
\hline $\mathbf{Z}$ & ن الصغرى & J & ن & المجموعة & المتغيرات \\
\hline \multirow[t]{2}{*}{., 190} & $0 \leqslant$ & $v, v_{1}$ & v & الضابطة & العمر الزمنـ \\
\hline & 01 & $V, r q$ & v & التجريبية & \\
\hline$\cdot, V Y \leq$ & $0 \wedge$ & $V, r q$ & v & الضابطة & الأكاء \\
\hline
\end{tabular}


أ.م.د/ عبير صديق أمين

فاعلية برنامج قائم على استراتيجيات التطلم النشط

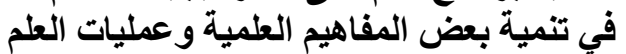
لاى طقل الروضة ضعيف السمع

\begin{tabular}{|c|c|c|c|c|c|}
\hline z & ن الصغرى & مرد & ن & المجموعة & المتغيرات \\
\hline & $\varepsilon V$ & $7, \times 1$ & v & التجريبية & \\
\hline \multirow{2}{*}{$\cdot, \leqslant 09$} & $\leqslant 9$ & v & v & الضابطة & \multirow{2}{*}{ الاعاقة السمعية } \\
\hline & 07 & $\wedge$ & v & التجريبية & \\
\hline \multirow[t]{2}{*}{$\cdot, \leqslant \leqslant V$} & $\leqslant १, 0$. & $v, \cdot v$ & v & الضابطة & \multirow[t]{2}{*}{ المفاهيم العلمية } \\
\hline & $00,0$. & V,qr & v & التجربيية & \\
\hline \multirow[t]{2}{*}{.,ONT } & or & $\Lambda, 1 \leq$ & v & الضـابطة & \multirow[t]{2}{*}{ عمليات العلم } \\
\hline & $\varepsilon \wedge$ & $7, \wedge 7$ & v & التجربيية & \\
\hline
\end{tabular}

يتضح من الجدول السابق عدم وجود فروق دالة احصائياً بين رثب درجات أطفال المجموعتين التجريبية و الضابطة على متغيرات البحث مما يدل على التكافؤ بين

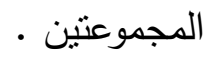

r. أدوات البحث: تم استخدام الأدوات التالية:

أ. مقياس ستانفورد - بينيه لقياس ذكاء الأطفال - الصورة الخامسة .(إعداد محمد

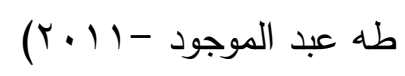

ب. مقياس المفاهيم العلمية المصور لطفل الروضة ضعيف السمع. (إعداد الباحثة)

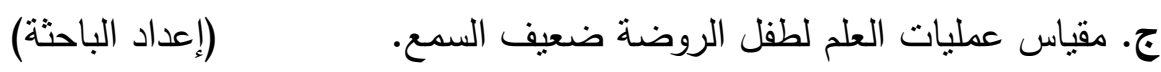
د. برنامج أنشطة تعليمية لتتمية بعض المفاهيم العلمية وعمليات العلم لطفل (إعداد الباحثة)

الروضة ضعيف السمع. 
أ. مقياس ستانفورد - بينيه لقياس ذكاء الأطفال - الصورة الخامسة .(إعداد محمد طه

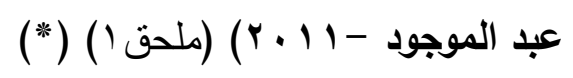

تهدف الصورة الخامسة للمقياس إلى قياس خمسة عوامل أساسية هي (الاستدلال

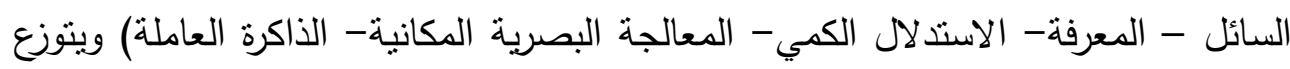
كل عامل من هذه العوامل على مجالين رئيسيين: المجال اللفظي والمجال غير اللفظي، وهكذا فإن الصورة الخامسة من مقياس ستانفورد بينيه تتكون من عشرة اختبارات فرعية،

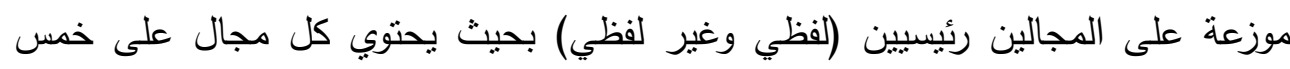

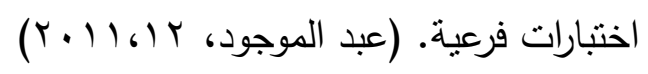

تم تقنين المقياس على عينة ممنلة للمجتمع الأمريكي بلغ عددها . . 1ـ فرد نتراوح

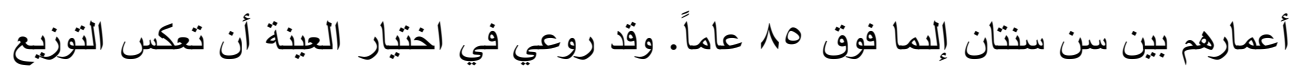

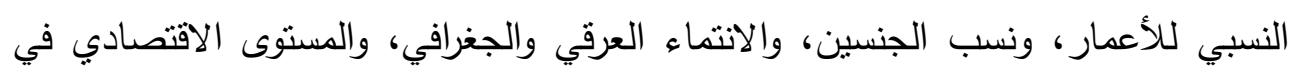
المجتمع الأصلي للعينة. وقد اثتملت هذه المجموعة على أفراد من الموهوبين فائقي الذكاء.

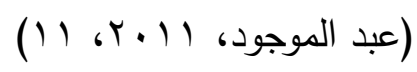

صدق المقياس: فقد أظهر المقياس ارتباطاً عالياً ودالاً بالعديد من مقاييس الذكاء الكلاسيكية مثل الصورة الرابعة من مقياس ستانفورد بينيه، واختبارات وكسلر لقياس ذكاء

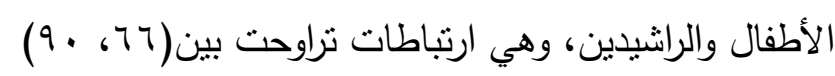

ثبات المقياس: نم حساب صدق التقسيم النصفي المعدل بمعادلة سبيرمان - براون للمقاييس الكلية والفرعية في المقياس، ووجد أن منوسط معامل ثبات المقاييس الفرعية كان

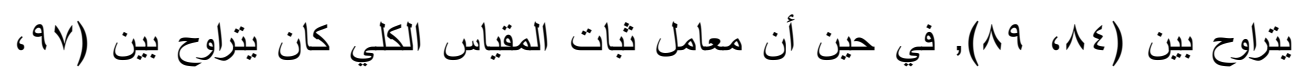

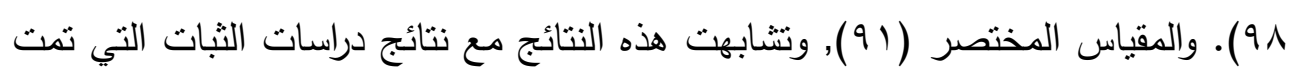

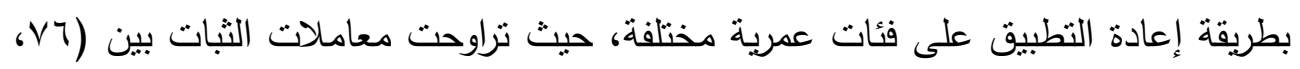

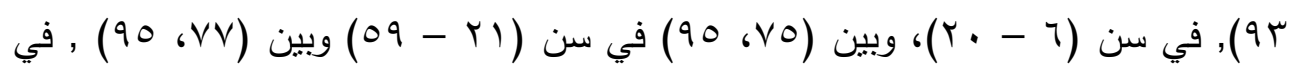


أ.م.د/ عبير صديق أمين

فاعلية برنامج قائم على استراتيجيات التطلم النشط

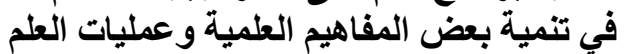
لاى طقل الروضة ضعيف السمع

سن • ج عاما أو بزيد. ولقد تم تطبيق المقياس بطريقة فردية على أطفال مركز الصم و

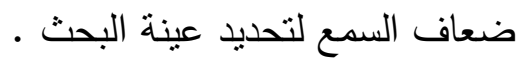

ب. مقياس المفاهيم العلمية المصور لطقل الروضة ضعيف السمع. (إعداد الباحثة) اللهُف من المقياس: يهدف المقياس إلى قياس مدى اكتساب طفل الروضة ضعيف السمع بعض المفاهيم العلمية هدف البحث من خلال برنامج أنشطة باستخدام بعض استراتيجيات التعلم النشط .ويتتاول المقياس ثناث محاور : هى:

1. مفاهيم بيولوجية: ويشمل: مفهوم الكائن الحي والجماد-مفهوم النبات- مفهوم

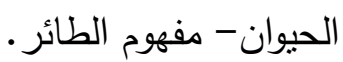

r. مفاهيم كيميائية : حالات الماء - الذوبان - الألوان الأساسية والفرعية. r. مفاهيم فيزيقية : مفهوم الحركة والسكون - الجاذبية - المغناطيسية - الطفو والغوص.

مصادر اشتقاق المقياس: قامت الباحثة بالإعتماد على مجموعة الكتب والمراجع

$$
\begin{aligned}
& \text { والبحوث والدراسات العلمية في مجال موضوع البحث. } \\
& \text { خطوات تصميم المقياس : }
\end{aligned}
$$

- الإطلاع على البحوث والدراسات السابقة المتعلقة بمتغيرات البحث بصفة عامة وبالمفاهيم العلمية بصفة خاصة والاستفادة منها في اعداد المقياس وبنوده.

- الإطلاع على مقاييس واختبارات متعلقة بالمفاهيم العلمية التي يمكن تتميتها لطفل الروضة عامة وضعيف السمع بصفة خاصة مثل مقياس المفاهيم البيولوجيه لمسلم

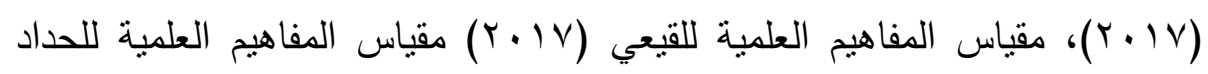

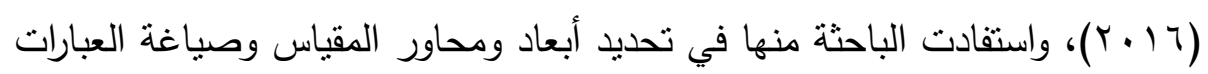

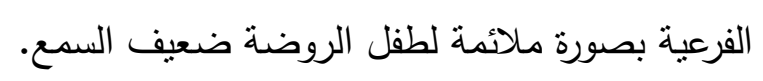

- نم اعداد المقياس مصوراً، وقد راعت الباحثة أن تكون الصورة مناسبة لمحتوى السؤال من جانب و لطبيعة وخصائص عينة البحث من جانب آخر . 
- تم اعداد المقياس في صورته المبدئية حيث تكون من (•7) مفردة حول ثناث أبعاد وهى: مفاهيم بيولوجية وتضمن (IM) سؤال، مفاهيم كيميائية (10) سؤال، مفاهيم فيزيقية وتضمن (ع () سؤال. وتم عرض المقياس على لهن مجموعة من المحكمين

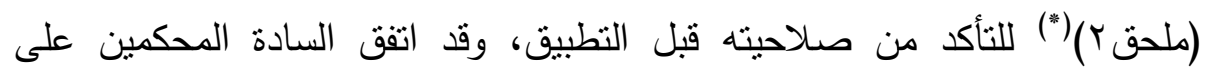
المحاور الرئيسية للمقياس، وعلى ضرورة اختصار عدد بنود المقياس، وفصل كل

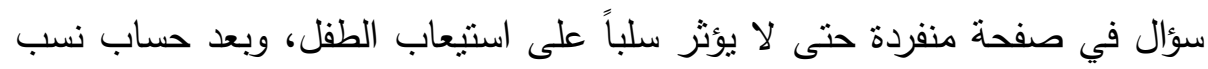
الاتفاق لكل بند قامت الباحثة بحذف البنود التي حصلت على لأثلى نسبة اتفاق أقل من

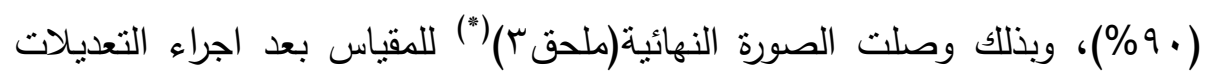

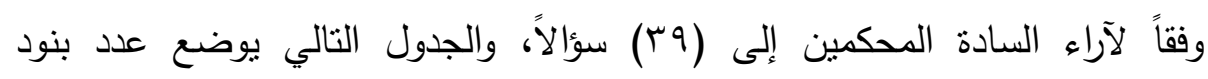
المقياس في الصورتين المبدئية والنهائية: جدول (r):عدد بنود مقياس المفاهيم العلمية المصور لطقل الروضة ضعيف السمع

\begin{tabular}{|c|c|c|c|}
\hline \multicolumn{2}{|c|}{ عدد الأسئلة } & \multirow{2}{*}{ أبعاد المقياس } & \multirow{2}{*}{ r } \\
\hline الصورة النهائية & الصورة المبدئية & & \\
\hline r & r & مفاهيم بيولوجية & 1 \\
\hline 1. & 10 & مفاهيم كيميائية & r \\
\hline$\wedge$ & $1 \leqslant$ & مفاهيم فيزيقية & $r$ \\
\hline$r q$ & 7. & المجموع & $\varepsilon$ \\
\hline
\end{tabular}

طريقة تطيق المقياس: يتم تطبيق المقياس عن طريق المقابلة الفردية لكل طفل على حدة، وقد نم التطبيق بالاستعانة ببعض معلمات المركز . 
أ.م.د/ عبير صديق أمين

فاعلية برنامج قائم على استراتيجيات التعلم النشط

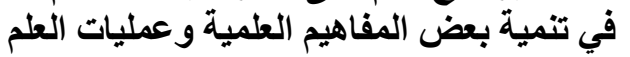
لاى طقل الروضة ضعيف السمع

زمن تطيق المقياس: نم تطبيق المقياس دون تحديد زمن للاجابة، وقد تراوح زمن تطبيق المقياس كمنوسط للزمن الذي استغرقه الأطفال في الدراسة الاستطلاعية ما بين

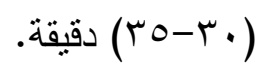

تعليمات المقياس:

- - ت تجم إجابة الطفل تحت إثراف الباحثة.

- - أن تُعين الباحثة الطفل على توضيح الجزء الغامض دون الإيحاء بالإجابة. - أن يكون هدف الأسئلة واضح للأطفال والباحثة. - - أن تكون ألوان الصور واضحة حتى ثثير إنتباه الأطفال.

- - أن يتم تطبيق المقياس في مكان هادئ حتى يتمكن الطفل ضعيف السمع من متابعة الباحثة و التعليمات.

\section{تصحيح المقياس:}

- - تقوم الباحثة أو المعلمة بتطبيق المقياس على أطفال العينة، ويراعى تشجيل

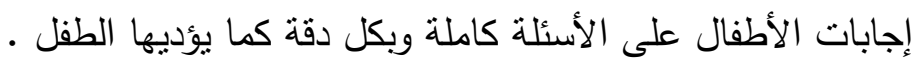

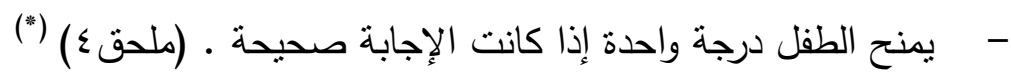

التقدير الكمي للمقياس: نم تحديد درجة واحدة لكل سؤال، وبذلك تكون الدرجة

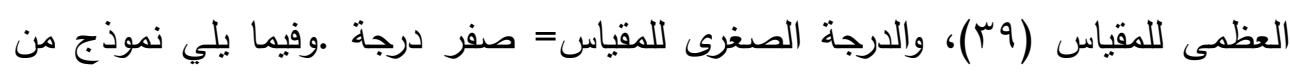
مقياس المفاهيم العلمية المصور لطفل الروضة ضعيف السمع. وله

(") ملحق(ع) مفتاح تصحيح مقياس المفاهيم العلمية المصور لطفل الروضة ضعيف السمع . 
المجلة العلمية لكلية رياض الاطفال - جامعة اسيوط

(أ) ضع علامة (ل) على صورة الحيوان الأليف .
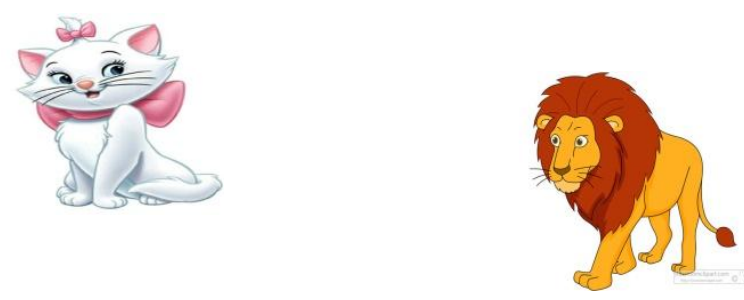

الخصائص السبكومترية لمقياس المفاهيم العلمبة المصور: قامت الباحثة بإيجاد معاملات الصدق والثبات على النحو التالى:

الصدق الظاهرى: حيث قامت الباحثة بعرض المقياس على مجموعة من المحكمين

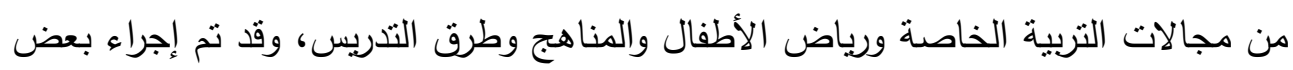

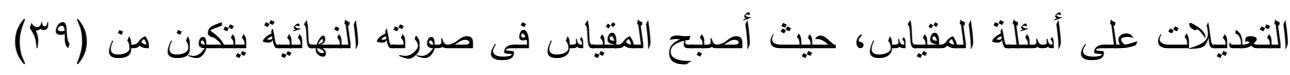
بطاقة،ثم قامت الباحثة بحساب نسبة الإتفاق بين المحكين على أسئلة المقياس حيث

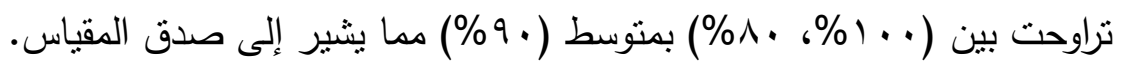

كما نم إستخدام طريقة الإتساق الداخلى من خلال نطبيق المقياس على عدد (10) طفلاً وطفلة من غير عينة البحث الأساسية، ومن خلال إيجاد معامل الإرتباط بين درجة الإنة كل محور والدرجة الكلية للمقياس، والجدول النالى يوضح النتيجة:

جدول ( ) ): معامل الإرتباط بين درجة كل محور والدرجة الكلية لمقياس المفاهيم العلمية

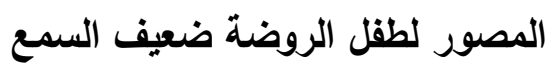

\begin{tabular}{|c|c|c|}
\hline معامل الصدق & محاور الدقياس & م \\
\hline די, & مفاهيم بيولوجية & 1 \\
\hline$\cdot, \wedge$ & مفاهيم كيميائية & r \\
\hline .,^. & مفاهيم فيزيقية & $r$ \\
\hline
\end{tabular}


يتضح من الجدول السابق أن معاملات الإرتباط لمحاور المقياس الثلاث تراوحت

ما بين (VT. . - . A. • ) وهى معاملات ارتباط دالة مما يدل على صدق المقياس.

ثبات المقياس: نم تطبيق مقياس المفاهيم العلمية المصور لطفل الروضة على

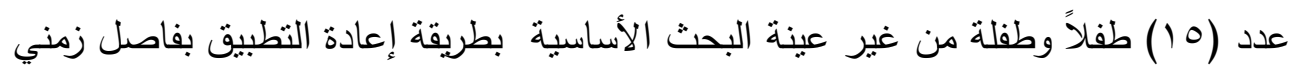
بين التطبيقين الأول والثاني (10) يوم، وتم حساب معامل الارتباط بينهما باستخدام معادلة سبيرمان، والجدول التالى يوضح النتيجة: جدول (•) معامل الإرتباط بين التطبيقين الأول والثانى لمقياس المفاهيم العلمية المصور لطفل الروضة ضعيف السمع لئع

\begin{tabular}{|c|c|c|}
\hline معامل الثبات & المحاور & 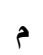 \\
\hline$\cdot, \Lambda r$ & مفاهيم بيولوجية & 1 \\
\hline.$\wedge v$ & مفاهيم كيميائية & r \\
\hline.$\wedge \varepsilon$ & مفاهيم فيزيقية & $r$ \\
\hline .99 & الارجة الكلية & $\varepsilon$ \\
\hline
\end{tabular}

يتضح من الجدول السابق أن معاملات الإرنباط لمحاور المقياس الثلاث تراوحت

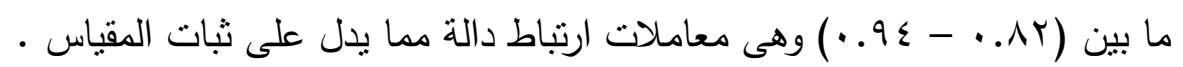
ج. مقياس عمليات العلم لطقل الروضة ضعيف السمع. (إعداد الباحثة) اللهُف من المقياس: يهدف المقياس إلى قياس مدى اكتساب طفل الروضة ضعيف السمع لبعض عمليات العلم هدف البحث من خلال برنامج أنشطة تعليمية باستخدام بعض استراتيجيات التعلم النشط من خلال ثلاث محاور وهي: الملاحظة - التصنيف الاستتناج.

\section{خطوات تصميم المقياس:}

- الاطلاع على البحوث والدراسات السابقة المتعلقة بمتغيرات البحث عامة وبعمليات العلم بصفة خاصة والاستفادة منها في اعداد المقياس. 


\section{المجلة العلمية لكلية رياض الاطفال - جامعة اسيوط}

- - الاطلاع على مقاييس واختبارات متعلقة بعمليات العلم التي يمكن تتميتها لطفل الروضة عامة وضعيف السمع بصفة خاصة مثل مقياس المهارات العلمية لحجاج

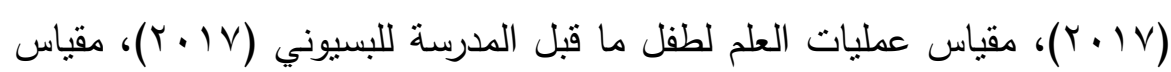

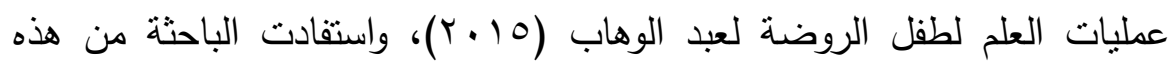

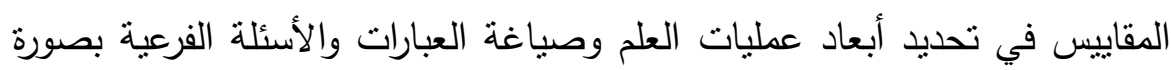

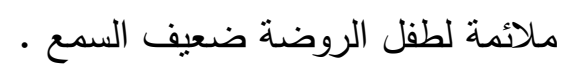
- - تم اعداد المقياس مصوراً / لفظياً، مع مراعاة مناسبة الصور والعبارات لكل سؤال من جهة ولطبيعة وخصائص عينة البحث من جهة أخرى حيث كان البعدين الأول

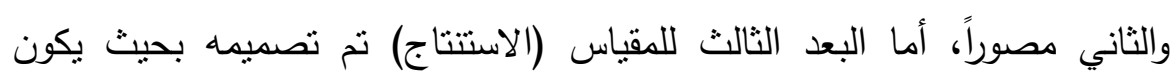
مصور / لفظي. - تم اعداد المقياس من (1) مفردة حول ثلاث أبعاد، حيث تضمن البعد الأول

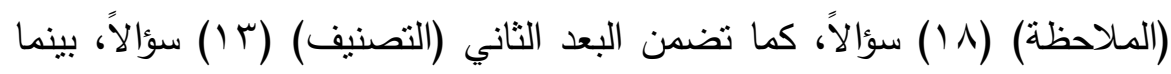

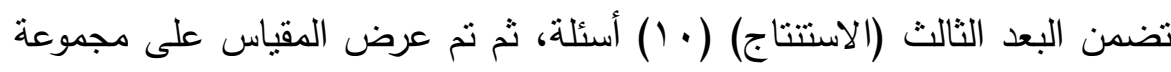
من المحكمين في مجال التربية وعلم النفس والمناهج وطرق التدريس والتربية

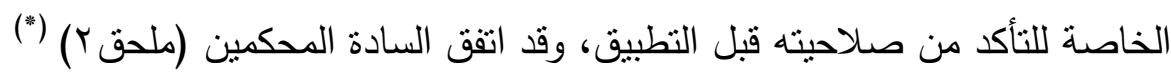

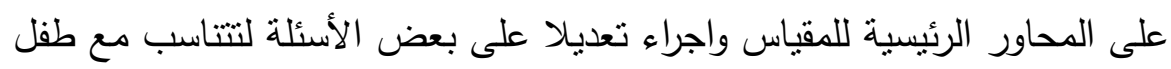

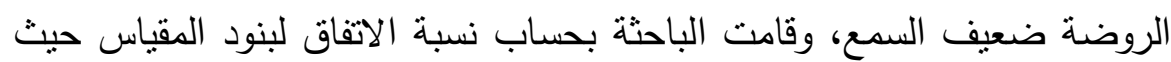

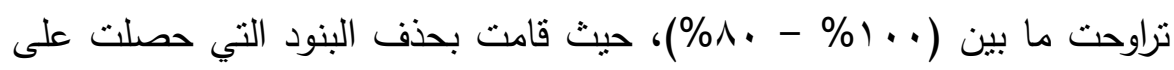

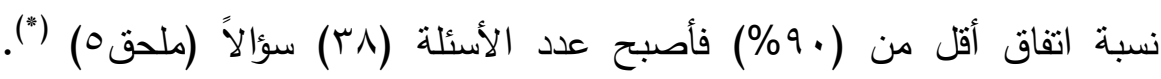
والجدول التالي يوضح عدد أسئلة المقياس في الصورتين المبدئية و النهائية . 
أ.م.د/ عبير صديق أمين

فاعلية برنامج قائم على استراتيجيات التعلم النشط

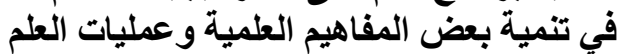
لاى طقل الروضة ضعيف السمع لئح

جدول (†): عدد بنود مقياس عمليات العلم لطقل الروضة ضعيف السمع

\begin{tabular}{|c|c|c|c|}
\hline \multicolumn{2}{|c|}{ عدد الأسئلة } & \multirow{2}{*}{ أبعاد المقياس } & \multirow{2}{*}{ p } \\
\hline الصورة النهائية & الصورة المبئية & & \\
\hline 10 & 11 & الملاحظة & 1 \\
\hline 1 & $1 \pi$ & التصنيف & r \\
\hline 1. & 1. & الاسنتتاج & r \\
\hline rᄉ & \&1 & المجموع & $\varepsilon$ \\
\hline
\end{tabular}

طريقة تطيق المقياس: يتم تطبيق المقياس عن طريق المقابلة الفردية لكل طفل على حدة، وقد تم الاستعانة ببعض معلمات المركز في تطبيق المقياس.

زمن تطيق المقياس: تم تطبيق المقياس دون تحديد زمن للاجابة، وقد تراوح زمن تطبيق المقياس كمتوسط للزمن الذي استغرقه الأطفال في الدراسة الاستطلاعية ما بين

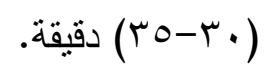

تعليمات المقياس: روعى عند تصميم تعليمات المقياس البساطة والوضوح والإختصار ، حيث أنها تميزت بما يلى لئى: روعى - تتم إجابة الطفل تحت إثراف الباحثة. - أن تُعين الباحثة الطفل على توضيح الجزء الغامض دون الإيحاء بالإجابة. - أن يكون هدف الأسئلة واضح للأطفال والباحثة . تصحيح المقياس: تم تقدير درجات المقياس على ثلاث مستويات كالتالي: - إذا أجاب الطفل إجابة صحيحة على مفردات المقياس بأخذ درجتان. - إذا تردد الطفل في الإجابة، وأجاب اجابة صحيحة يأخذ درجة واحدة. 
- إذا أجاب إجابة خاطئة يأخذ صفراً . (ملحق7)(")

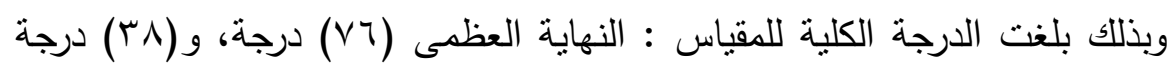

للوسطى، وصفر درجة للصغرى • وفيما يلي نموذج للمقياس.

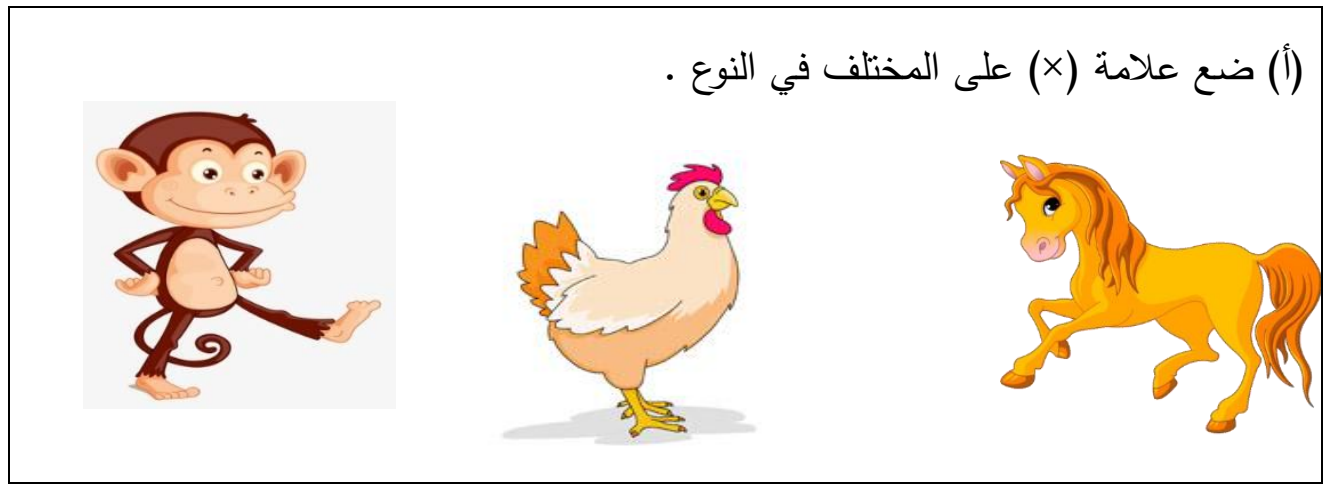

الخصائص السيكومترية لمقياس عمليات العلم: قامت الباحثة بإيجاد معاملات الصدق والثبات على النحو التالى:

الصدق الظاهرى: حيث قامت الباحثة بعرض المقياس على مجموعة من المحكمين من مجالات التربية الخاصة و رياض الأطفال والمناهج وطرق التدريس، وقد تم إجراء بعض التعديلات على أسئلة المقياس، حيث أصبح المقياس فى صورته النهائية يتكون من (^^) مفردة،ثم قامت الباحثة بحساب نسبة الإتفاق بين المحكمين على أسئلة المقياس

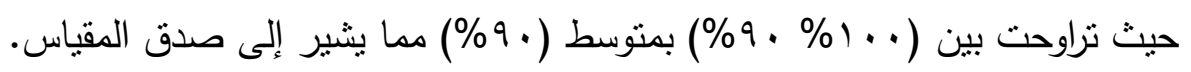
كما تم إستخدام طريقة الإتساق الداخلى من خلا تطبيق المقياس على عدد (10) طفلاً وطفلة من غير عينة البحث الأساسية، ومن خلال إيجاد معامل الإرتباط بين درجة

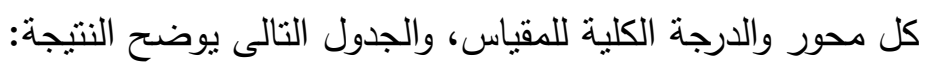


أ.م.د/ عبير صديق أمين

فاعلية برنامج قائم على استراتيجيات التعلم النشط

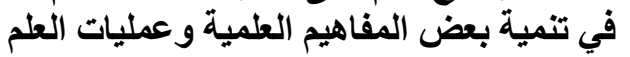
لاى طفل الروضة ضعيف المغية السمع

جدول (V) معامل الإرتباط بين درجة كل محور والدرجة الكلية لمقياس

عمليات العلم لطقل الروضة ضعيف السمع

\begin{tabular}{|c|c|c|}
\hline معامل الصدق & محاور المقياس & م \\
\hline$\cdot, \wedge \wedge$ & الملاحظة & 1 \\
\hline י & التصنيف & $r$ \\
\hline$\cdot, 70$ & الاستتتاج & $r$ \\
\hline
\end{tabular}

يتضح من الجدول السابق أن معاملات الإرتباط لمحاور المقياس الثناث تراوحت

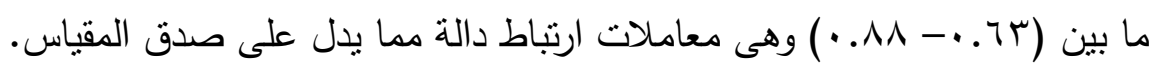

ثبات المقياس: نم تطبيق مقياس عمليات العلم لطفل الروضة ضعيف السمع على

عدد (10) طفلاً وطفلة من غير عينة البحث الأساسية بطريقة إعادة النطبيق بفاصل زمني فئي بين التطبيقين الأول والثاني (10) يوم، وتم حساب معامل الارتباط بينهما باستخدام معادلة سبيرمان، والجدول التالى يوضح النتيجة:

جدول (^) معامل الإرتباط بين التطبيقين الأول والثانى لمقياس عمليات العلم لطفل الروضة ضعيف السمع الأطين

\begin{tabular}{|c|c|c|}
\hline معامل الثبات & المحاور & p \\
\hline$\cdot, \wedge \vee$ & الملاحظة & 1 \\
\hline.$v_{0}$ & التصنيف & $r$ \\
\hline .91 & الاستنتاج & $r$ \\
\hline.$\wedge V$ & الدرجة الكلية & ○ \\
\hline
\end{tabular}


يتضح من الجدول السابق أن معاملات الإرتباط لمحاور المقياس الثناث تراوحت

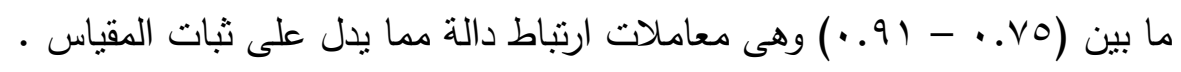
د. برنامج أنشطة لتنمية بعض المفاهيم العلمية وعمليات العلم لطفل الروضة ضعيف السمع.((إعداد الباحثة)

وفى هذا الجزء يجيب البحث عن السؤال الثالث والذى ينص على: ما مكونات

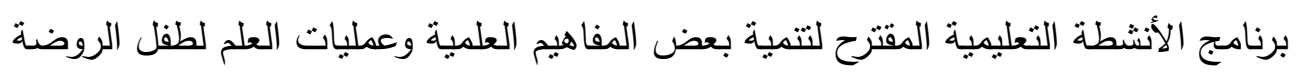
ضعيف السمع؟ برنج حيث قامت الباحثة بتحديد الأهداف العامة لبرنامج الأنشطة التعليمية المقترح وفقاً

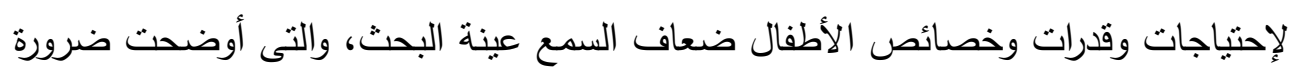

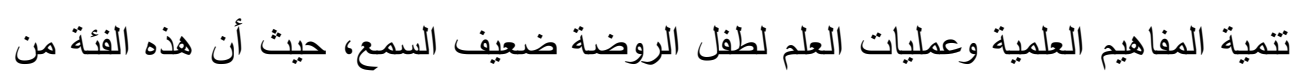
الأطفال فى حاجة إلى اكتساب المفاهيم العلمية وعمليات العلم واستخدام استراتيجيات التعلم

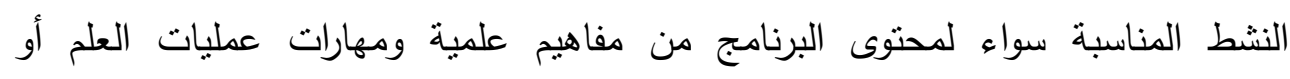

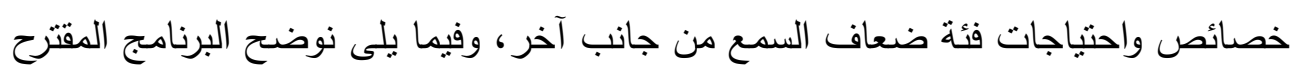
بالتقصيل.

\section{فلسفة برنامج الأنشطة التعليمية :}

قامت الباحثة باعداد برنامج أنشطة لاكساب طفل الروضة ضعيف السمع بعض

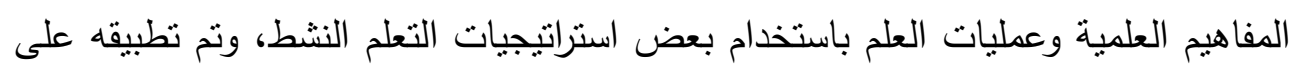

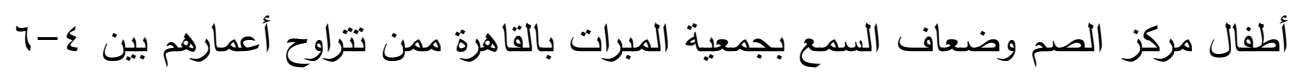

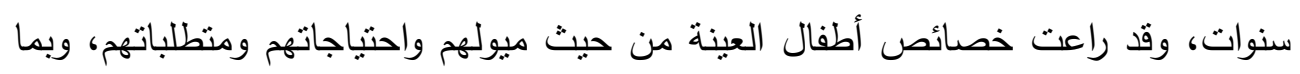

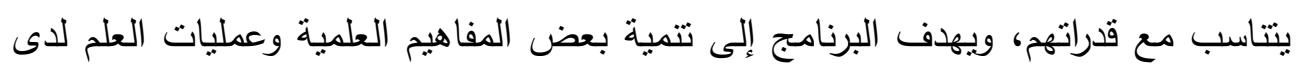

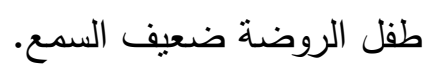




\section{المبادئ والأسس العامة لبرنامج الأنشطة التعليمية:}

- يعتمد العمل مع quht hgslu على الأنشطة الفردية فى بعض الأحيان نظراً

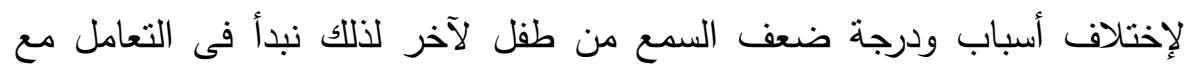
الطفل من ضعاف السمع لتأكيد ذاته ثم العمل على تقدمه وسط الجماعة مع مراعاة الفروق الفردية بين أفراد الجماعة أيضاً. - - استتارة دوافعهم للإتجاه نحو عملية التعلم وذللك وفقاً لخصائصهم مع مراعاة أن لديهم انخفاض فى الدافعية، فعلى المعلمة أن تعرض مثيرات قوية جداً تعمل على إثارة ذاته نحو المشاركة والعمل فى البرنامج الموحه إليه.

- تفعيل دور الطفل يعمل على تحقيق الطفل لذاته أى أن تعتدد الأنشطة التعليمية المتضمنه فى البرنامج على النشاط الذاتى للطفل فيستطيع ملاحظة التغير الناتج على أدائه وحصوله على منتج من صناعته. - استخدام الحواس كمخل رئيسى فى التعامل مع الأطفال ضعاف السمع حيث أن هناك صعوبة فى التعامل مع المفاهيم المجردة.

- استخدام استراتيجيات تعليمية مناسبة لضعيف السمع يؤدى إلى المشاركة الفعالة للطفل.

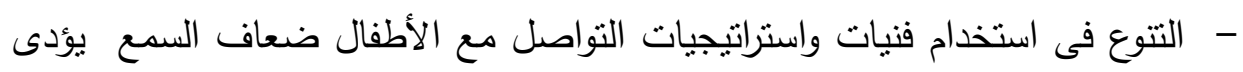

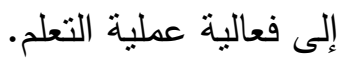

- التدرج فى أنشطة البرنامج فتلك الفئة من الأطفال يعانون من عدم القدرة على الإنتباه والاستمرار تجاه المثيرات المعروضة عليهم، فيجب أن ينم تدريب الطفل بكل جوانبه

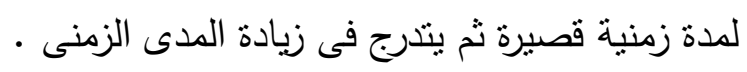
- أن تكون الوسائل التعليمية فى البرنامج جذابة بحيث يتجه إليها الطفل محاولاً التعرف على مضمونها بحيث تحتوى هذه الوسائل على عنصر الحركة والألوان الجذابة إضافة إلى عنصر السلامة والأمن عند استخدام الطفل لها. - - إعداد بيئة التعلم المناسبة لخصائص ضعاف السمع والمنمنلة فى: 
• أن تكون قاعة النشاط بعيدة عن الضوضاء والمؤثرات الخارجية التى نشتت

$$
\text { انتباه الأطفال. }
$$

$$
\text { • أن تكون القاعة جيدة الإضاءة والتهوية. }
$$

تحتوى على المعينات السمعية الفردية والجماعية المناسبة لأطفال هذه الفئة. أن تخلو قاعة النشاط من اللوحات المعلقة على الجدران حيث يؤدى وجودها إلى تشتت الإنتباه البصرى ويمكن أن تحتوى القاعة على بعض النه الألوان

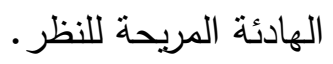

إجراء عملية التقييم من خلال المراحل الثناث المتمثلة فى التقييم القبلى

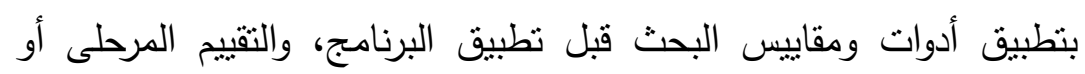
التكوينى فى نهاية كل نشاط أثناء نطبيق البرنامج، ثم التقبيم النهائى أو أونى البعدى بتطبيق أدوات ومقاييس البحث المقترحة.

الأهداف العامة لبرنامج الأنشطة التعليمية: يهدف برنامج الأنشطة التعليمية المقترح إلى: "تنمبة بعض المفاهيم العلمبة لاى ضعاف السمع فى رياض الأطفال" ويتم تحقيق هذا الهدف من خلال مجموعة من الأهداف الفرعية وهى: 1. تتمية بعض المفاهيم البيولوجية لدى طفل الروضة ضعيف السمع. r. تتمية بعض المفاهيم الكيمبائية لدى طفل الروضة ضعيف السمع. r. تتمية بعض المفاهيم الفيزيقية لدى طفل الروضة ضعيف السمع. *"تنمبة بعض عمليات العلم للى طفل الروضة ضعيف السمع" ويتم تحقيق هذا الهدف من خلال مجموعة من الأهداف الفرعية وهى : ا ـ تتمية مهارة الملاحظة لدى طفل الروضة ضدئ ضعيف السمع. r. . تتمية مهارة التصنيف لدى طفل الروضة ضعيف السمع.

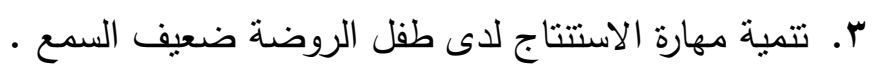


الأهداف الإجرائبة لبرنامج الألعاب التعليمية: تم تحديد الأهداف الإجرائية للبرنامج، وقد

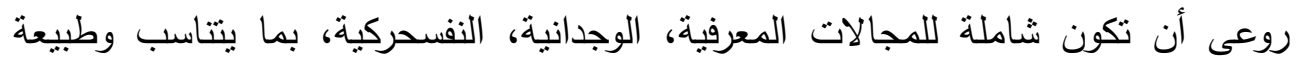

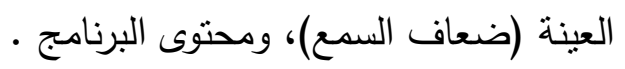

محتوى البرنامج: بعد تحديد الأهداف، تم تقديم محتوى ومحاور البرنامج الذى من

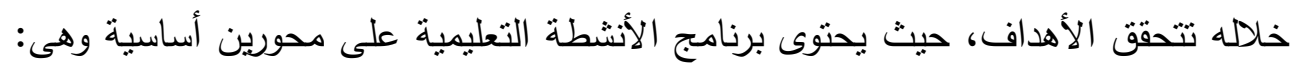

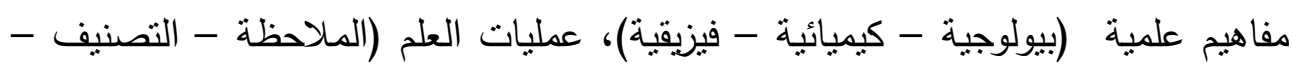

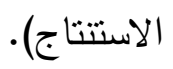

وقد تم إختيار محتوى برنامج الأنشطة التعليمية من خلال الإعتماد على المصادر

التعرف على خصائص وسمات الأطفال ضعاف السمع فى مرحلة رياض الأطفال من خلال المراجع والكتب العلمية والدراسات والبحوث ذات الصلة بعينة البحث. التعرف على حاجات الأطفال التعليمية من خلال دراسة عينة البحث والتعرف على منطلباتها للإندماج مع زويهم، وكذلك المفاهيم العلمية وعمليات العلم الواجب تتميتها، واستغلال استمتاع الأطفال بالأنشطة التعليمية ودورها فى العملية التعليمية. وقد قامت الباحثة بالإطلاع على العديد من المراجع العلمية والدراسات السابقة المرتبطة بموضوع البحث، مما ساعد في نرجمة محتوى البرنامج إلى مجموعة من الأنشطة

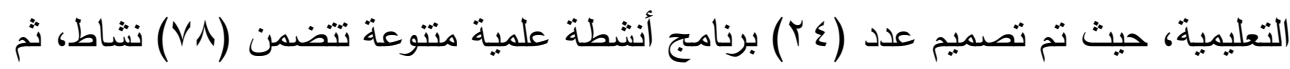
تم عرض البرنامج على مجموعة من الأساتذة المحكمين(ملحق ب)(") والخبراء في مجال رياض الأطفال والمناهج وطرق التدريس للتعديل أو الحذف أو الإضافة في البرنامج المقترح.

وقد اتفقت مجموعة الأساتذة المحكمين على الأسس العلمية لوضع البرنامج والأهداف التربوية، وكذلك المحتوى، والأنشطة، مع بعض الملاحظات، وبعد إجراء 
التعديلات في بعض الأهداف، أساليب التقويم، أصبح البرنامج صالحاً للتطبيق على عينة

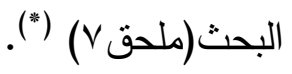
الإستراتيجيات التطليمية : يعتد البحث الحالى على بعض استراتيجيات التعلم النشط وهى

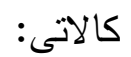

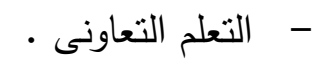
- - n - استراتيجية الاكتثاف - - متراتيجية الالعاب التعليمية . -

الجدول الزمني للبرنامج: قسم البرنامج المقترح على (^) أسبوع بواقع ثلاث أيام

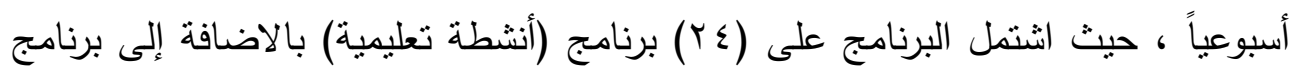

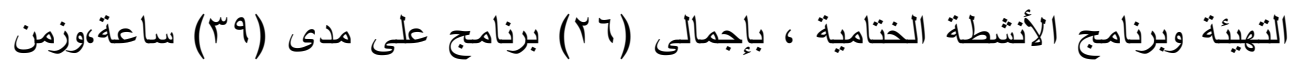

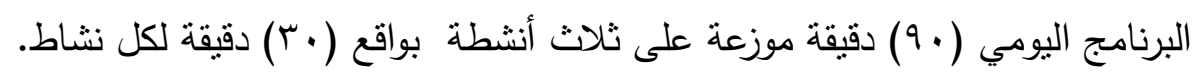
تجربة البحث الأساسية : تكونت تجربة البحث الأساسية من ثلاث مراحل: 1. القباس القبلي: نم تطبيق القياس القبلي لعينة البحث لمتغير المفاهيم العلمية وعمليات العلم لدى أطفال المجموعتين التجريبية والضابطة. r. تطبيق البرنامج المقترح: تم تطبيق برنامج الأنشطة التعليمية المقترح على أطفال المجموعة التجريبية ضعاف السمع، وتم تطبيق البرنامج بواقع (، (9) دقيقة يومياً

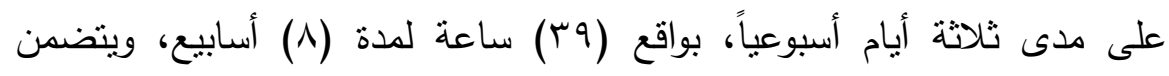
البرنامج المفاهيم قيد البحث وهى: مفاهيم بيولوجية - مفاهيم كيميائية- مفاهيم

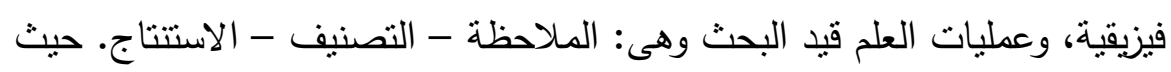

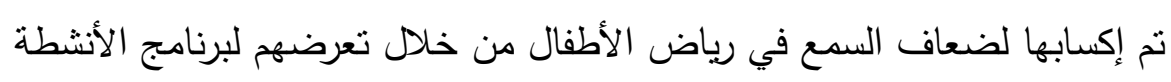

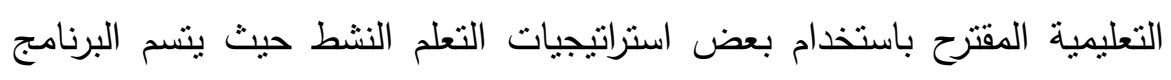

(*) ملحق (V) . برنامج أنشطة لتنمية بعض المفاهيم العلمية وعمليات العلم لطفل الروضة ضعيف السمع. 
أ.م.د/ عبير صديق أمين

فاعلية برنامج قائم على استراتيجيات التعلم النشط

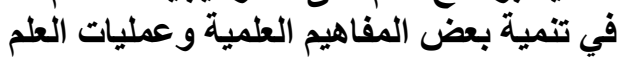
لاى طقل الروضة ضعيف السمع

بالمرونة والتتوع في الأنشطة بما يتتاسب والاحتباجات التدربيية لعينة البحث، وبالتالي اندماجهم ومشاركتهم بشكل إيجابي في الأنشطة.

r. القياس البعدي: بعد انتهاء الفترة المحددة للتطبيق تم إجراء القياس البعدي لمتغير

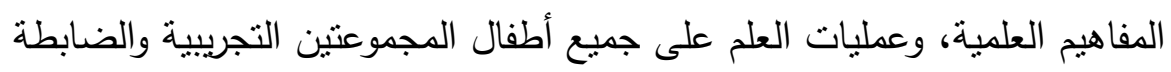
بنفس الثروط التي تمت في القياس القبلي. إجراءات البحث: قامت الباحثة بإتباع الإجراءات التالية:

ا ـ تم دراسة مجتمع البحث (أطفال مركز الصم وضعاف السمع) لتحديد عينة البحث،

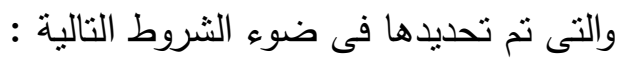
أ. يتراوح العمر الزمنى بين (ع-7) سنوات . .

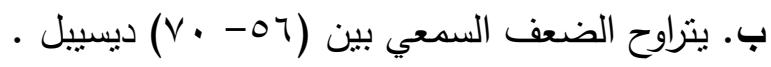
ج. الخلو من المشكلات الصحية الواضحة التي قد تؤثز على أداء الأطفال في

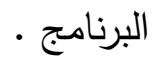

د. الإلتزام فى الحضور للمركز وبالتالى برنامج الأنشطة التعليمية المقترح •

r. تم عمل حصر للروضة لتحديد القاعة المناسبة قبل البدء في إجراءات التطبيق. r. تم نطبيق الاختبارات والمقاييس المستخدمة على الأطفال عينة البحث للتأكد من مناسبتها لعينة البحث.

$$
\text { ه. ه. تم حساب المعاملات العلمية لأدوات البحث (الصدق والثبات). }
$$

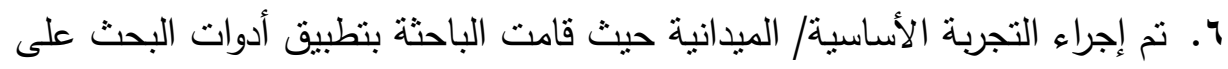
أطفال المجموعتين التجريبية والضابطة، ثم نطبيق البرنامج المقترح على أطفال المجموعة التجريبية، ثم تطبيق أدوات البحث على أطفال الهموعتين التجريبية والضابطة. 
الأساليب الإحصائية المستخدمة: تم استخدام المعالجات الإحصائية التالية: - معامل الارتباط للنحقق من صدق وثبات أدوات البحث (مقياس المفاهيم العلمية

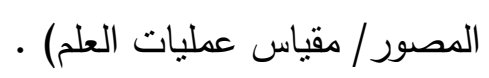

- معادلة كوبر Cooper لحساب نسبة الاتفاق بين الملاحظين •

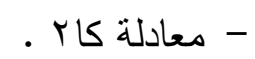

- اختبار ولكوكسن Wilcoxon) لحساب دلالة الفروق بين القياسين القبلي والبعدي

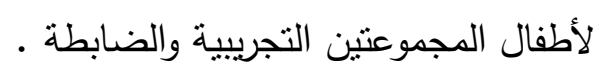
- اختبار ويتتي (U.Test) لحساب دلالة الفروق بين المجموعتين التجريبية والضابطة في القياسين القبلي والبعدي.

خامساً: التحقق من صحة الفروض وعرض وتفسير النتائج: نتتاول فيما يلي نتائج البحث في ضوء الفروض، وما أسفرت عنه الدراسة

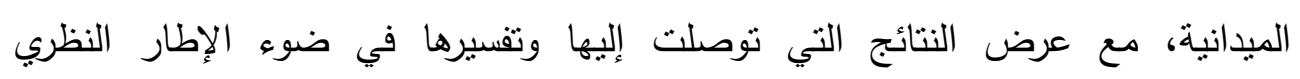

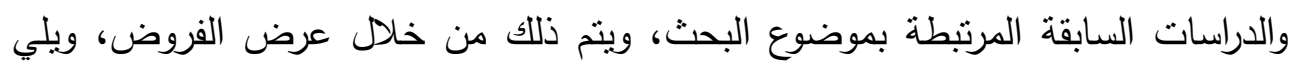
ذلك المعالجات الإحصائية ثم عرض النتيجة ثم مناقثنة وتقسير هذه النتيجة.

\section{التحقق من صحة الفرض الأول:}

ينص الفرض الأول على: لاتوجد فروق ذات دلالة إحصائية بين متوسطات رتب درجات أطفال المجموعة الضابطة في القياسين القبلي والبعدي على (مقياس المفاهيم

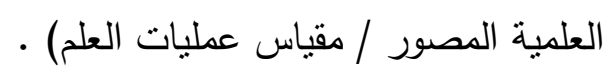
وللتحقق من صحة هذا الفرض تم حساب دلالة الفروق بين متوسطات رتب درجات الأطفال على (مقياس المفاهيم العلمية المصور / مقياس عمليات العلم) باستخدام اختبار ولكوكسن (Wilcoxon) كما يوضحه الجدول التالي: 
أ.م.د/ عبير صديق أمين

فاعلية برنامج قائم على استراتيجيات التطلم النشط

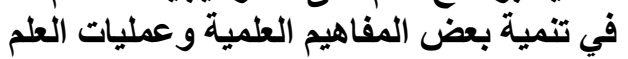
لاى طقل الروضة ضعيف السمع

جدول (9): يوضح دلالة الفروق بين رتب درجات أطفال المجموعة الضابطة في القياسين القبلي والبعدي على(مقياس المفاهيم العلمية المصور / مقياس عمليات العلم) باستخدام

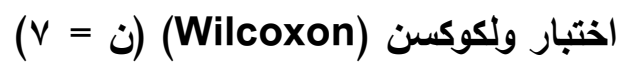

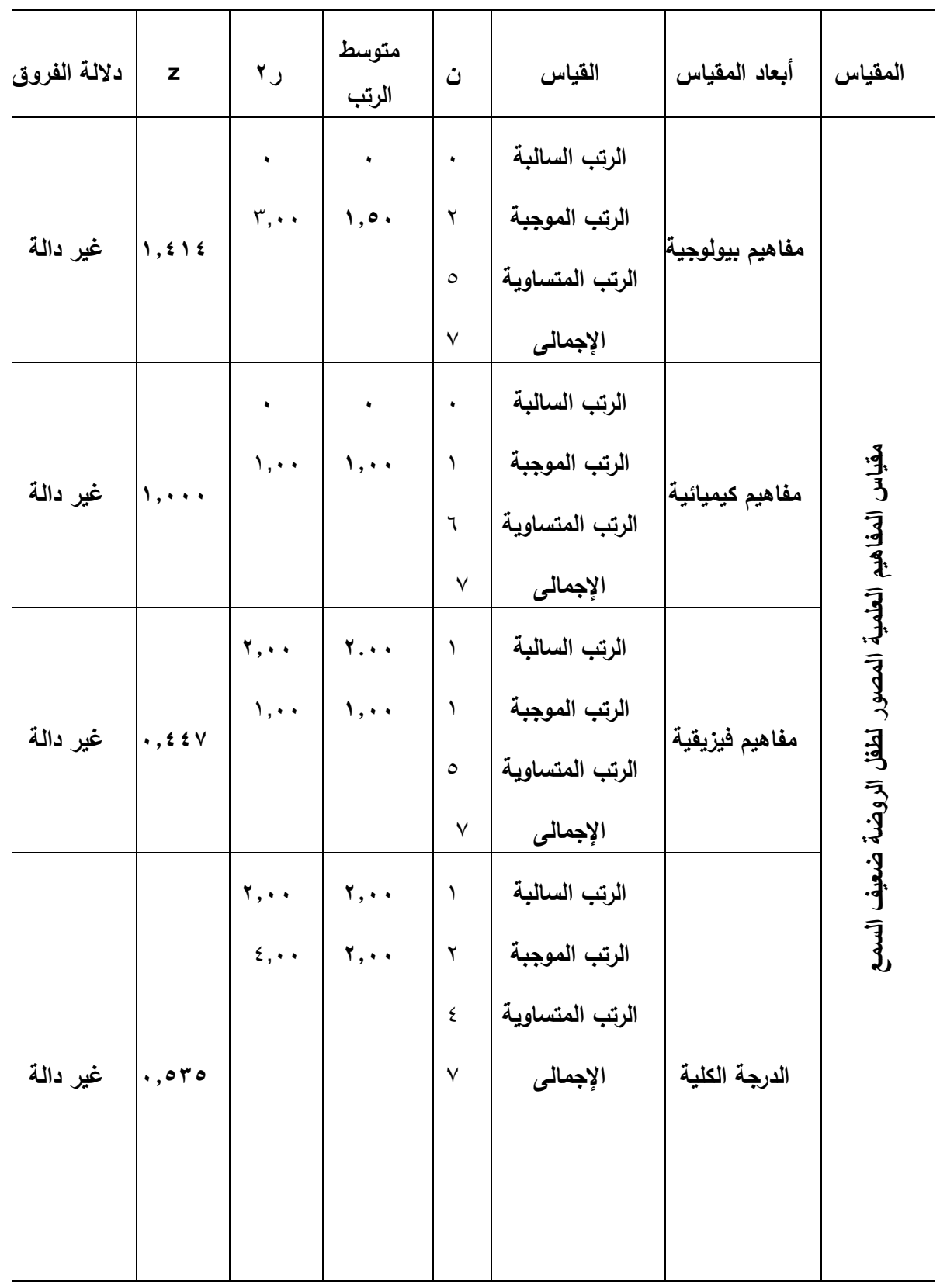


المجلة العلمية لكلية رياض الاطفال - جامعة اسيوط

\begin{tabular}{|c|c|c|c|c|c|c|c|}
\hline دلالة الفروق & $z$ & ז & متوسط & ن & القياس & أبعاد المقياس | & المقياس \\
\hline غير دالة &.,$O \vee V$ & $\begin{array}{l}r, \ldots \\
\varepsilon, \cdots\end{array}$ & $\begin{array}{l}r, \ldots \\
r, \ldots\end{array}$ & r & الرالرتب الرتب الموجبة المبتة & الملاحظة & \multirow{4}{*}{ 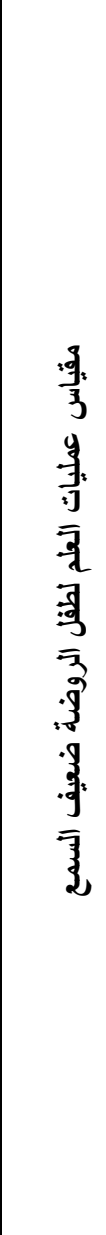 } \\
\hline غير دالة & $\cdot, 117$ & $\begin{array}{l}1,0 . \\
\varepsilon, 0 .\end{array}$ & $\begin{array}{l}1,0 . \\
\text { r,Yo }\end{array}$ & r & الرالرتب الرتب الموجبة الربة & التصنيف & \\
\hline غير دالة & $\cdot, \Delta \vee V$ & $\begin{array}{l}\varepsilon, \ldots \\
r, \ldots\end{array}$ & $\begin{array}{l}r . . \\
r, \ldots\end{array}$ & 1 & الرالرتب الرتب الموجبة الربة & الاستنتاج & \\
\hline غير دالة & $\cdot, \varepsilon \leqslant V$ & $\begin{array}{l}1, \ldots \\
r, \ldots\end{array}$ & $\begin{array}{l}1, \ldots \\
r, \ldots\end{array}$ & v & الرالرتب السالبة الرتب الموجبة & الارجة الكلية | & \\
\hline
\end{tabular}

يتضح من جدول (9) عدم وجود فروق ذات دلالة إحصائية بين متوسطات رتب

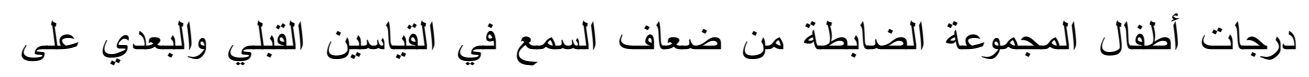

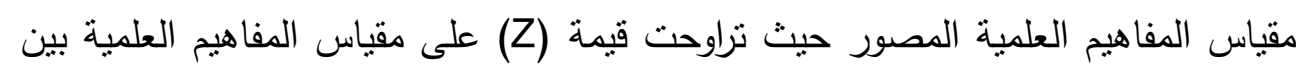

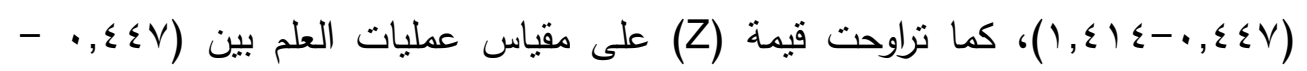

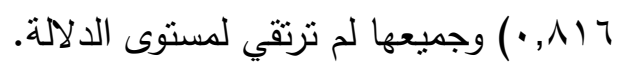


وتُرجع الباحثة النتيجة إلى عدم تعرض أطفال المجموعة الضابطة لبرنامج الأنشطة

المقترح الذي يعتمد على استخدام استراتيجيات التعلم النشط والتى تعتمد على التفاعل الايجابي من جانب المتعلم مما يكون له أكبر الأثر في اكتساب الخبرات المختلفة وامتداد تأثثرها على خبرات الطفل، بالاضافة إلى ضعف الخبرات المقدمة لطفل الروضة ضعيف السمع في مجال المفاهيم عامة بدعوى احتياجاجهم للنمو اللغوي سواء من جانب المعلمات أو أولياء الأمور مما يؤثر سلباً على شخصية الطفل في هذه المرحلة.

Jong , T ., Linn ,M ., Zacharia ) وتنفق نتائج البحث مع توصيات دراسة

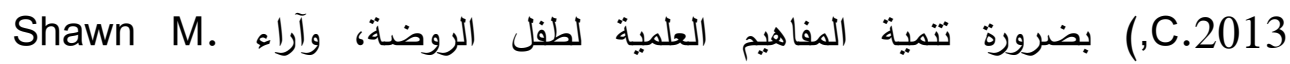

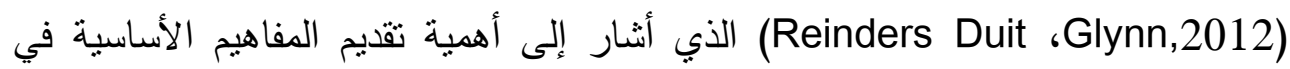

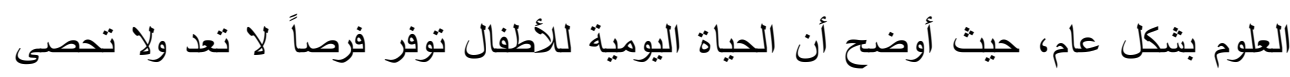
للاتفاعل مع مجموعة متتوعة من المواد، ومراقبة ممنلكاتهم والتغييرات التي يخضعون لهاء لهاه وهكذا.

وتخلص الباحثة مما سبق إلى تحقق صحة الفرض الأول في عدم وجود فروق دالة إحصائيا بين متوسطات رثب درجات أطفال المجموعة الضابطة في القباسين القبلي

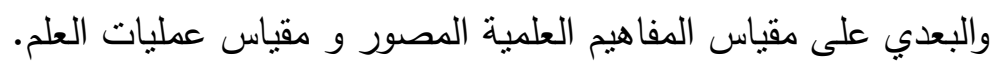
التحقق من صحة الفرض الثاني: ينص الفرض الثاني على: نوجد فروق ذات دلالة إحصائية بين متوسطات رثب درجات أطفال المجموعة التجريبية في القياسين القبلي والبعدي على (مقياس المفاهيم العلمية المصور / مقياس عمليات العلم) لصالح القياس البعدي. وللتحقق من صحة هذا الفرض تم حساب دلالة الفروق بين منوسطات رتب درجات

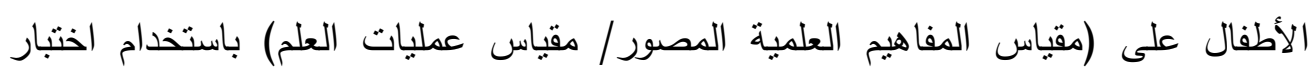
اختبار ولكوكسن (Wilcoxon) كما يوضحه الجدول التالي: 
المجلة العلمية لكلية رياض الاطفال - جامعة اسيوط

جدول ( • 1 ) يوضح دلالة الفروق بين رتب درجات أطفال المجموعة التجريبية في القياسين القبلي والبعدي على مقياس المفاهيم العلمية المصور و مقياس عمليات العلم

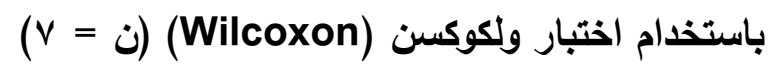

\begin{tabular}{|c|c|c|c|c|c|c|c|}
\hline الفروق & z & ני & متوسط & ن & القياس & أبعاد & المقياس \\
\hline$\cdot, \cdot+1$ & r,rvo & $\cdot$ & $\stackrel{\cdot}{\lfloor, \cdot}$ & $\begin{array}{l}\cdot \\
\text { v } \\
\cdot \\
\text { v }\end{array}$ & 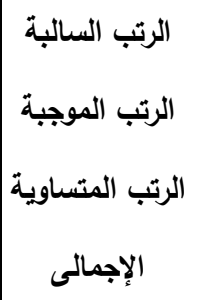 & مفاهيم & \\
\hline$\cdot, \cdot 1$ & $r, r \wedge \wedge$ & rA & $\stackrel{\cdot}{\lfloor, \cdot}$ & $\begin{array}{l}v \\
\text { v } \\
v\end{array}$ & الرال الرتب المتبلة المتالبة & كيميائية & $\begin{array}{l}\frac{9}{3} \\
\overline{3} \\
\frac{9}{9} \\
\overline{3}\end{array}$ \\
\hline$\cdot, \cdot 1$ & $r, \leqslant 1 \leqslant$ & rA & $\stackrel{\cdot}{\lfloor, \cdot}$ & $\begin{array}{l}\cdot \\
\text { v } \\
\text { v }\end{array}$ & الرالرتب الرتب المالبة & فيزيقية & $\begin{array}{l}\overline{3} \\
3 \\
3 \\
3 \\
\overline{3} \\
\overline{3} \\
3 \\
3\end{array}$ \\
\hline$\cdot, \cdot 1$ & r,Y4T & $r \wedge$ & 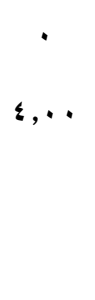 & $\begin{array}{l}\cdot \\
\text { v } \\
\text { v }\end{array}$ & 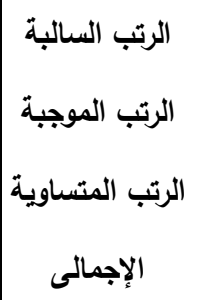 & الدرجة الكلية & $\overline{3}$ \\
\hline
\end{tabular}


أ.م.د/ عبير صديق أمين

فاعلية برنامج قائم على استراتيجيات التعلم النشط

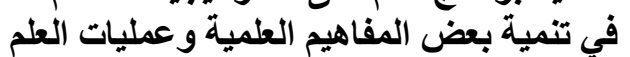
لاى طقل الروضة ضعيف السمع لئح

\begin{tabular}{|c|c|c|c|c|c|c|c|}
\hline الفروق & z & ر & متوسط الرتب & $\dot{ن}$ & القياس & أبعاد أبعاس & المقياس \\
\hline$\cdot,+1$ & r, rצ & rA & $\begin{array}{c}\cdot \\
\varepsilon, \cdots\end{array}$ & $\begin{array}{l}\cdot \\
v \\
\text { v } \\
\text { v }\end{array}$ & الرالرتب الرتب المالبة المتبة الرتبة & الملاحظة & \\
\hline$\cdot, \cdot 1$ & $r, r v i$ & rA & $\begin{array}{c}\cdot \\
\leq, \ldots\end{array}$ & $\begin{array}{l}\cdot \\
\text { v } \\
\text { v } \\
\text { v }\end{array}$ & الرالرتب الرتب المالبة المتباوية & التصنيف & 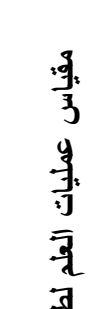 \\
\hline$\cdot, \cdot 1$ & $r, r v i$ & rᄉ & $\begin{array}{c}\cdot \\
\varepsilon, \ldots\end{array}$ & $\begin{array}{l}\cdot \\
\text { v } \\
\text { v } \\
\text { v }\end{array}$ & الرالرتب الرتب الموجبة المتبة & الاستنتاج & $\begin{array}{l}\overline{3} \\
.9 \\
: 3 \\
3 \\
3 \\
3 \\
\overline{3} \\
3\end{array}$ \\
\hline$\cdot, \cdot 1$ & $r, r v \theta$ & rی & $\begin{array}{c}\cdot \\
\varepsilon, \ldots\end{array}$ & $\begin{array}{l}\cdot \\
\text { v } \\
\text { v } \\
\text { v }\end{array}$ & الرالرتب الرالبة الرتبة المتبة & الارجة الكلية & \\
\hline
\end{tabular}

يتضح من جدول (·•) وجود فروق ذات دلالة إحصائية بين منوسطات رثب

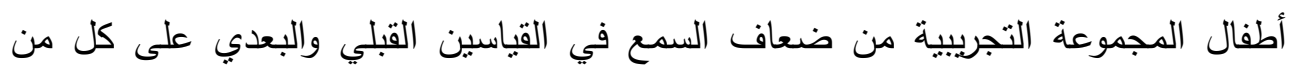

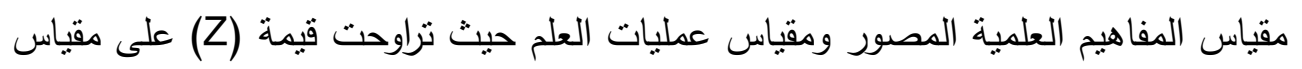

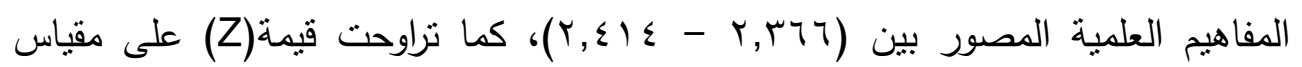

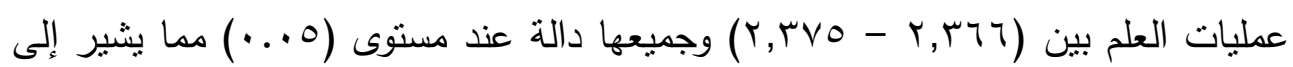




\section{المجلة العلمية لكلية رياض الاطفال - جامعة اسيوط}

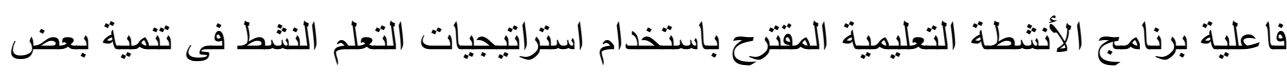
المفاهيم العلمية و عمليات العلم قيد البحث لدى طفل الروضة ضعيف لاديف السمع. تُرجع الباحثة الفروق بين القياسين القبلي و البعدي إلى تعرض أطفال المجموعة التجريبية لبرنامج الأنشطة التعليمية بما يحتويه من مفاهيم علمية وعمليات العلم المرتبطة بها مع مراعاة مناسبة مجموعة المفاهيم العلمية وعمليات العلم المرتبطة بها من واقع بيئة الطفل فيبدأ البرنامج من حيث يعرف الطفل وانطلاقاً من خبراته ويرتقي بمستوى المفاهيم والمهارات العلمية، كما يتيح ذلك نوظيف خبراته في الواقع سواء داخل أو خارج الروضة دئة وذللك يمثل أهم احتباجات طفل الروضة ضعيف السمع أن تتصف خبراته بالواقعية والقابلية للنطبيق.

كما راعي برنامج الأنشطة المقترح أسس تصميم البرنامج من حيث استتارة دوافع

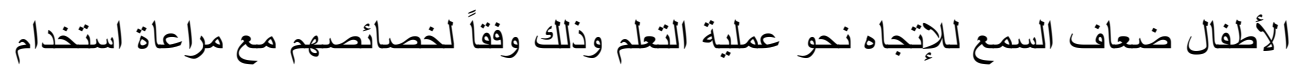
مثيرات قوية جداً تعمل على إثارة الأطفال نحو المشاركة والعمل فى البرنامج الموجه إلبهم. ومما ساهم في تحقيق تلك النتيجة تفعيل دور الطفل من خلال مساعدته على أن

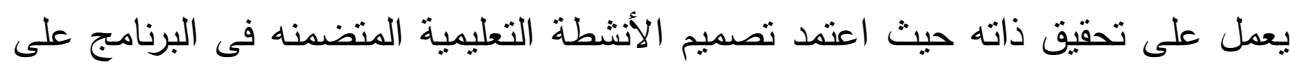

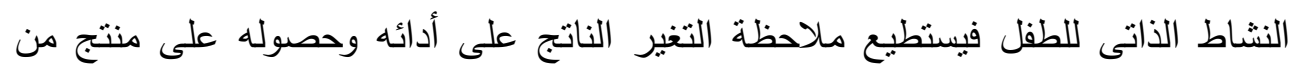
صناعته، بالاضافة إلى اعتماد البرنامج على استخدام الحواس كمدخل رئيسى فى التعامل

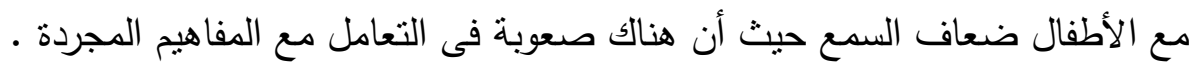
وحيث أن ضعاف السمع يعانون من عدم القدرة على الإنتباه والاستمرار تجاه

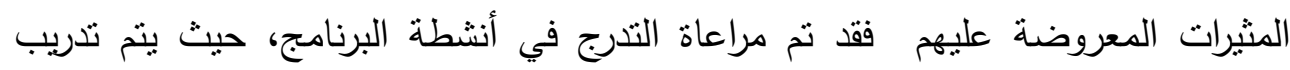

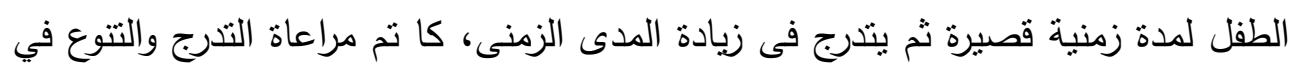
مستوى صعوبة الأنشطة.

ومن حيث التقنيات التربوية اهتم البرنامج بأن تتميز بالجاذبية مما بشجع الطفل

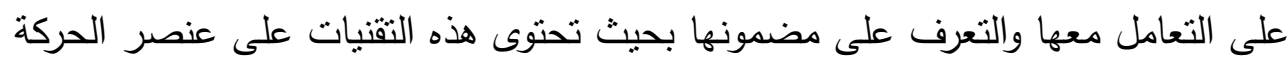
والألوان الجذابة إضافة إلى عنصر السلامة والأمن عند استخدام الطفل لها، مع مراعاة 
التتوع والتذرج من النماذج الحقيقية والصور والنماذج البلاستيك والثمعية والأنشطة

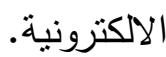

كما تُرجع الباحثة النتيجة إلى اعتماد البرنامج المقترح على الخبرة المباشرة القريبة

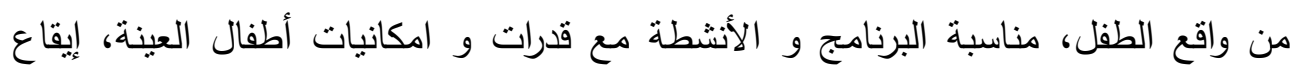
الأنشطة يسير حسب سرعة الطفل، محور البرنامج هو الطفل ذاته .. اهتماماته، امكانياته، قدراته، احتياجاته، اهتمام البرنامج بالأشطة الوظيفية التي تسمح للطفل بتوظيف و تطبيق البرنيق

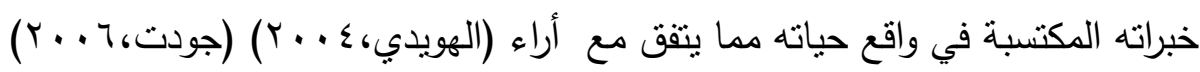

كما ثُرجع الباحثة الفروق بين القباسين القبلي والبعدى لأفراد المجموعة التجريبية

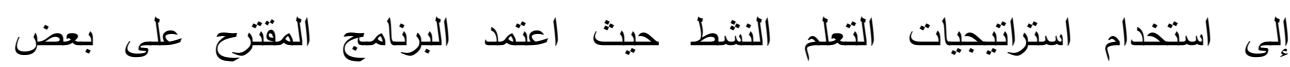

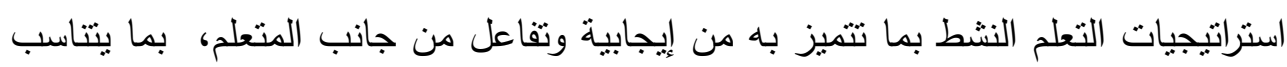

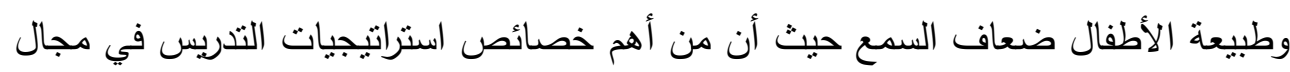

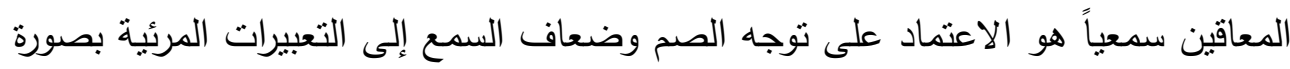

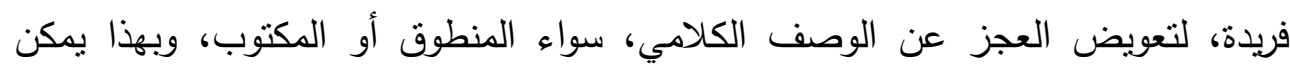

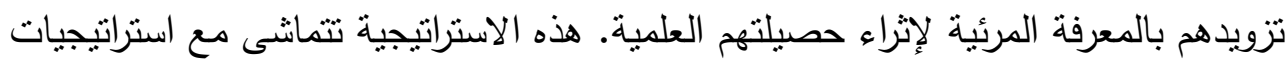

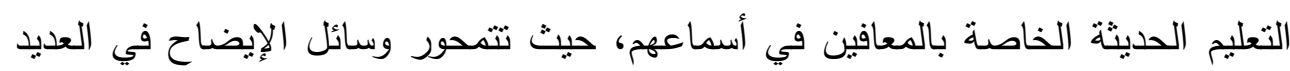
من المجالات في استخدام الصور والفيديو والنماذج المجسمة، والرسوم البيانية والإيضاحية

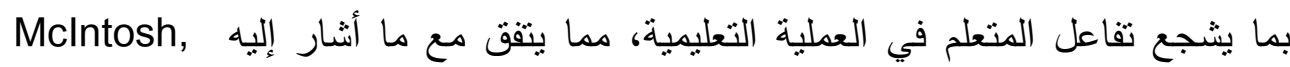

(R.A., 2005)

وتتفق نتائج البحث مع أراء (Lorenzen,M,2006) من حيث أن استراتيجيات

التعلم النشط تسمح للمتعلمين بالمشاركة الفاعلة فى الانشطة داخل الحجرة الصفية بحيث تأخذهم إلى ما هو أبعد من دور الثخص المستمع السلبى إلى الثخص الثص الذصى دئى بأخذ زمام المبادرة فى الأنشطة المختلفة التى يمارسها مع زملائه، على دأنى أن يكون دور المعلم توجيه

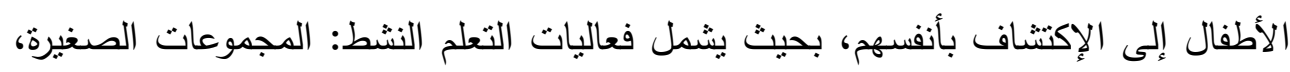

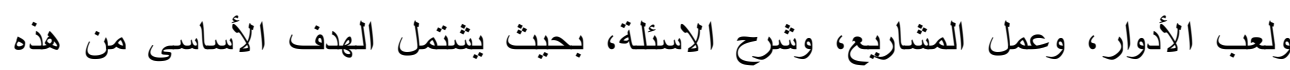
الانشطة تشجيع الاطفال على تعليم أنفسهم بأنفسهم تحت الثراف المعلمة. 
حيث أن استخدام استراتيجيات التدريس المتمركزة حول المتعلم والتى تتتاسب مع قدراته،

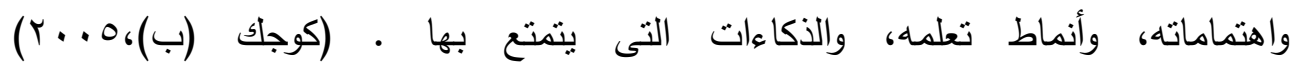

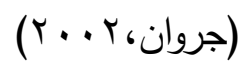

كما تتفق النتيجة مع ما أثنارت إليه الدراسات السابقة من فاعلية توظيف استراتيجيات التعلم النشط في تتمية بعض المفاهيم العلمية لدى طفل الروضة منها دراسة

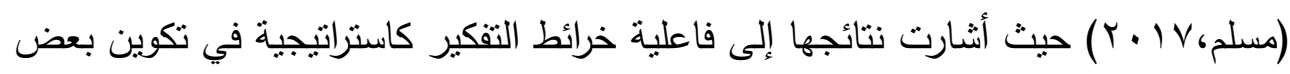

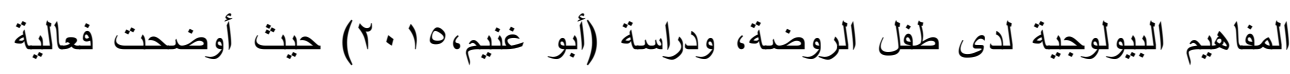

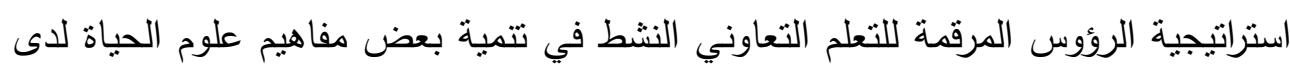

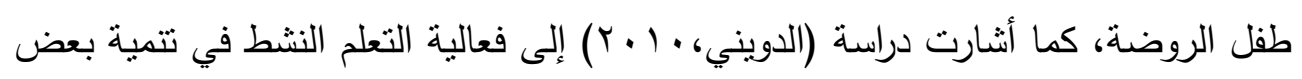
مهارات عمليات العلم لدى طفل الروضة.

كما ثُرجع الباحثة الفروق بين القيلسين القبلي و البعدى لأطفال المجموعة التجريبية

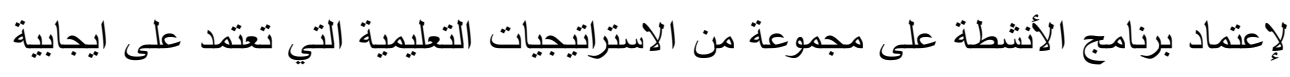

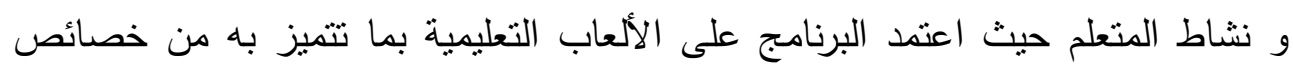

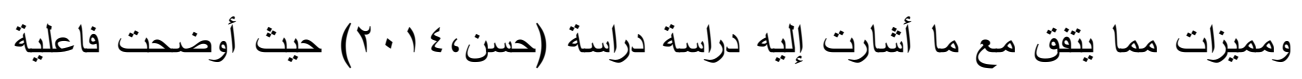

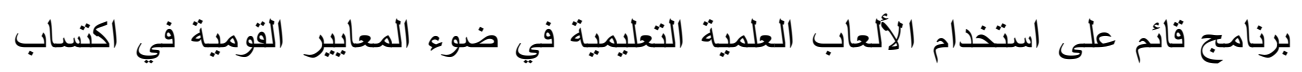
المفاهيم العلمية وتتمية بعض مهارات عمليات العلم الأساسية والتفكير الابتكاري لدى أطفال

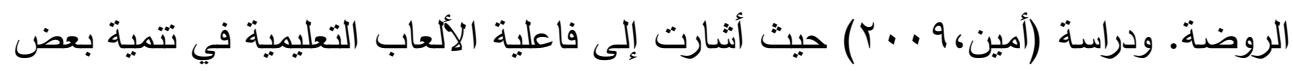

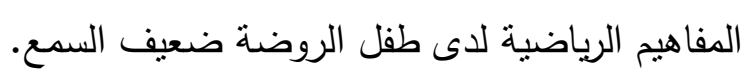
كما تتفق النتيجة مع ما أثنارت إليه الدراسات والبحوث من فاعلية استراتيجية التعلم

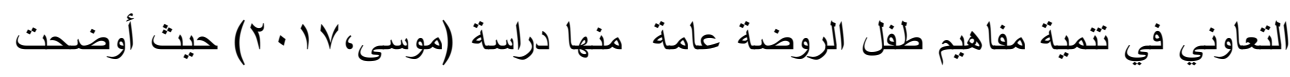

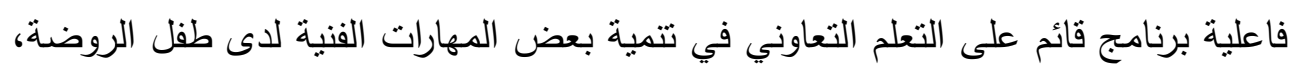

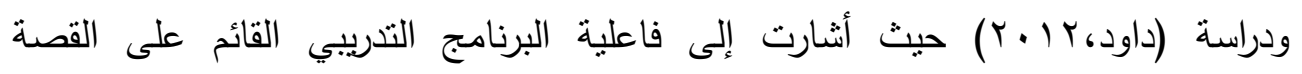
الموسيقية الحركية لتعديل بعض سلوكيات الطفل المشكل في رياض الأطفال في ضورء استراتيجيات التعلم التعاونى. 
كما تتفق النتيجة السابقة مع آراء برونر حيث أثنار إلى أن التعلم بالاكتثاف يزيد

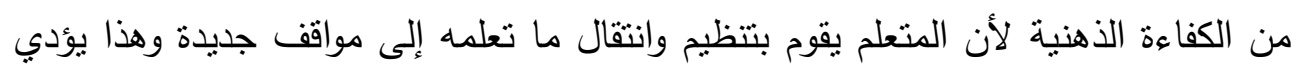

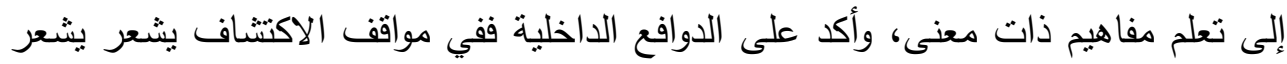

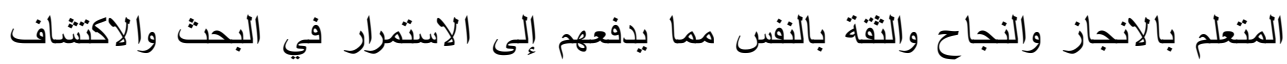

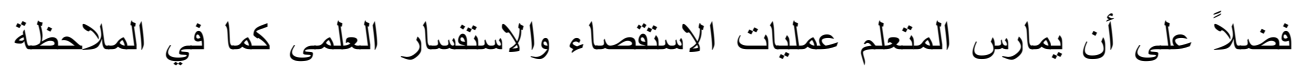

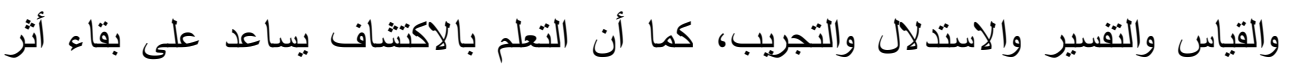

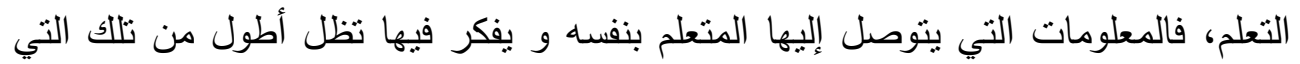

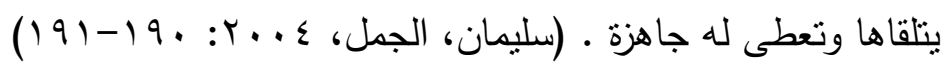

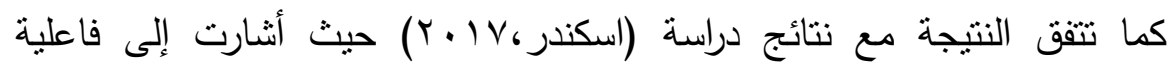

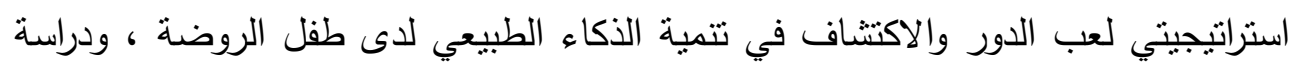

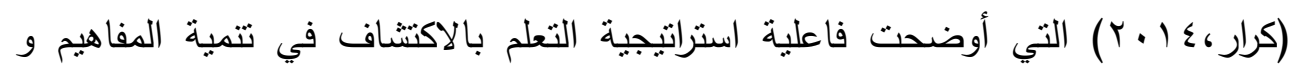

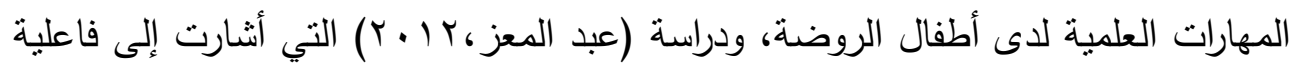

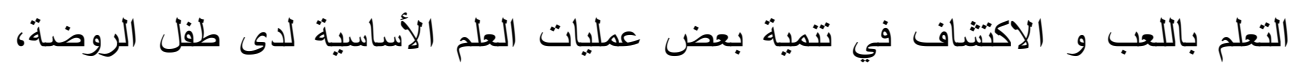

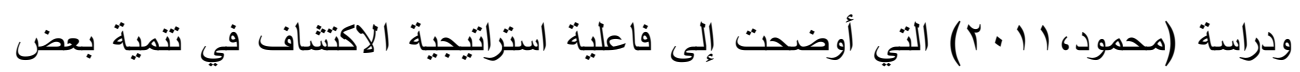
المفاهيم و التفكير الاستقرائي لدى أطفال ما قبل المدرسة. واعتماداً على حقيقة أن طفل الروضة ضعيف السمع من حقه الاستفادة من الخبرات الموجهة لطفل الروضة عادي السمع فمن الضروري تزويده بالمعارف العلمية

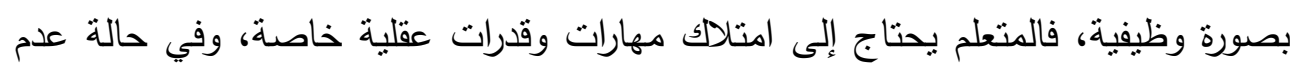

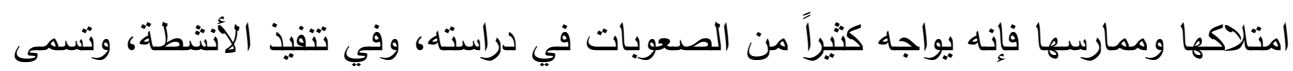

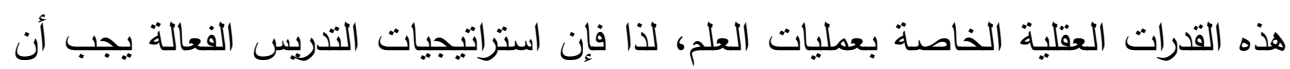

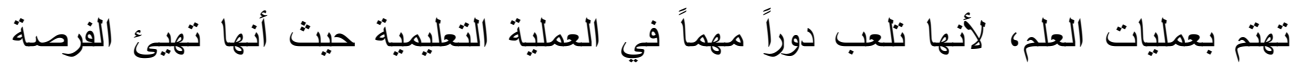

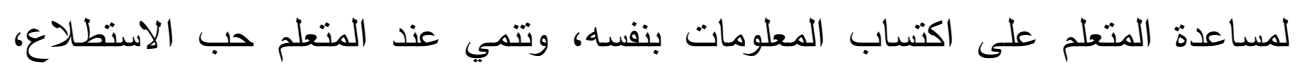
والبحث عن المسببات التي تكمن وراء الظواهر ، واكتساب المتعلم لهذه العمليات ينتقل أثره

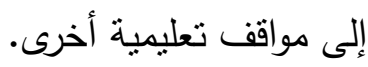


وتخلص الباحثة مما سبق إلى تحقق صحة الفرض الثاني في وجود فروق دالة إحصائيا بين متوسطات رثب درجات أطفال المجموعة التجريبية في القياسين القبلي والبعدي على مقياس المفاهيم العلمية المصور ومقياس عمليات العلم لصالح القياس البعدي. التحقق من صحة الفرض الثالث:

ينص الفرض الثالث على : توجد فروق ذات دلالة إحصائية بين متوسطات رتب درجات أطفال المجموعتين التجريبية والضابطة في القياس البعدي على ( مقياس المفاهيم العلمية المصور / مقياس عمليات العلم) لصالح المجموعة التجريبية.

وللتحقق من صحة هذا الفرض تم حساب دلالة الفروق بين متوسطات رتب درجات

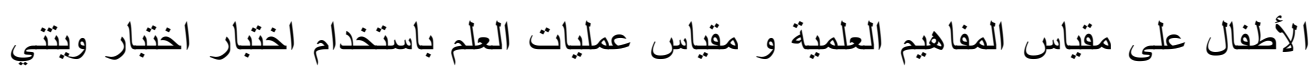
كما يوضحه الجدول التالي: (u.Test)

جدول (11) : يوضح دلالة الفروق بين متوسطات رتب درجات أطفال المجموعتين

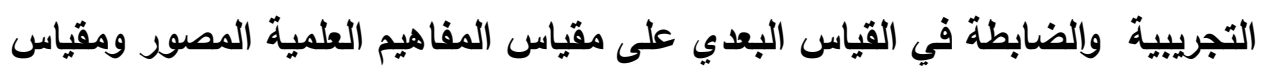

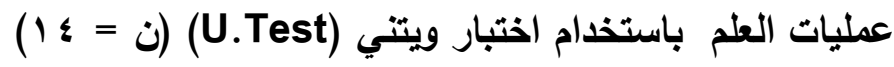

\begin{tabular}{|c|c|c|c|c|c|c|}
\hline $\mathbf{Z}$ & ن الصغرى & مر & ن & المجموعة & أبعاد المقياس & المقياس \\
\hline \multirow[t]{2}{*}{ r, } & rA & $\varepsilon$ & v & الضابطة & \multirow[t]{2}{*}{ مفاهيم بيولوجية } & \multirow{8}{*}{8} \\
\hline & $v V$ & 11 & v & التجريبية & & \\
\hline \multirow[t]{2}{*}{ r, IVT } & rA & $\varepsilon$ & v & الضابطة & \multirow[t]{2}{*}{ مفاهيم كيميائية } & \\
\hline & vV & 11 & $\checkmark$ & التجريبية & & \\
\hline \multirow[t]{2}{*}{ r...ov } & rq & $\varepsilon, 1 \varepsilon$ & v & الضابطة & \multirow[t]{2}{*}{ مفاهيم فيزيقية } & \\
\hline & $V Y$ & $1 \cdot, \wedge 7$ & $v$ & التجريبية & & \\
\hline \multirow[t]{2}{*}{$r, 1 \leqslant \Lambda$} & $r \wedge$ & $\varepsilon$ & $v$ & الضابطة & \multirow[t]{2}{*}{ الارجة الكلية } & \\
\hline & $v V$ & 11 & v & التجريبية & & \\
\hline
\end{tabular}




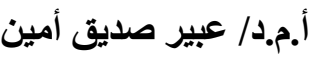

فاعلية برنامج قائم على استراتيجيات التعلم النشط

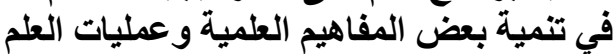

لاى طقل الروضة ضعيف السمع لئح

\begin{tabular}{|c|c|c|c|c|c|c|}
\hline Z & ن الصغرى & مر & ن & المجموعة & أبعاد المقياس & المقياس \\
\hline \multirow[t]{2}{*}{$r, 1 \leq \varepsilon$} & rA & $\varepsilon$ & v & الضابطة & \multirow[t]{2}{*}{ الملاحظة } & \multirow{8}{*}{$\begin{array}{l}E \\
E \\
E \\
E \\
E \\
E \\
E \\
E\end{array}$} \\
\hline & $V V$ & 11 & v & التجريبية & & \\
\hline \multirow[t]{2}{*}{$r, 170$} & rA & $\varepsilon$ & v & الضابطة & \multirow[t]{2}{*}{ التصنيف } & \\
\hline & VV & 11 & $v$ & التجريبية & & \\
\hline \multirow[t]{2}{*}{$r, 1 \leq \Lambda$} & rA & $\varepsilon$ & $v$ & الضابطة & \multirow[t]{2}{*}{ الاستتتاج } & \\
\hline & $v V$ & 11 & $v$ & التجريبية & & \\
\hline \multirow[t]{2}{*}{ r., } & rᄉ & $\varepsilon$ & v & الضابطة & \multirow[t]{2}{*}{ الارجة الكلية } & \\
\hline & VV & 11 & v & التجريبية & & \\
\hline
\end{tabular}

يتضح من جدول (1) (1) وجود فروق ذات دلالة إحصائية بين متوسطات رتب درجات

أطفال المجموعتين التجرييية والضابطة في القياس البعدي على كل من مقياس المفاهيم

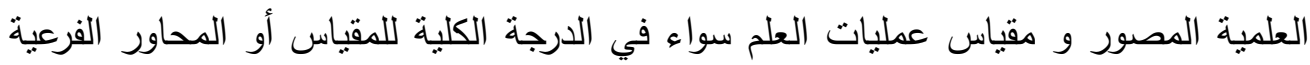
لكل منها، مما يثير إلى فاعلية برنامج الأنشطة التعليمية المقترح باستخدام استراتيجيات

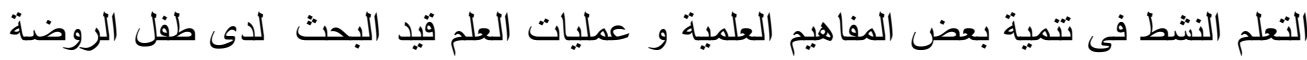
ضعيف السمع.

تتفق هذه النتيجة مع نتيجة الفرض الثاني والتي أوضحت فاعلية البرنامج المقترح

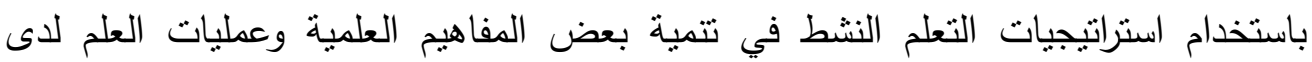

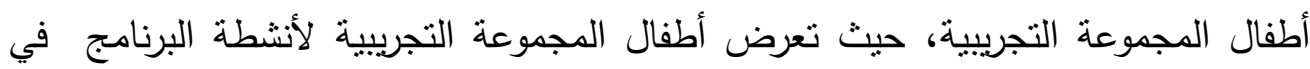
الوقت الذي تتسم خبرات طفل الروضة ضعيف السمع بضعف الخبرات العلمية حيث تركز أنشطة المركز على الأنشطة اللغوية دون الاهتمام بمفاهيم الطفل عامة والمفاهيم العلمية

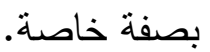

وحيث أن المفاهيم تمنل معنى العلم وتحقق وظيفته في الملاحظة والتفسير والضبط

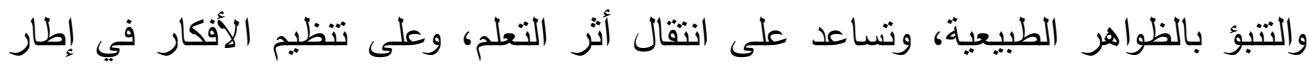

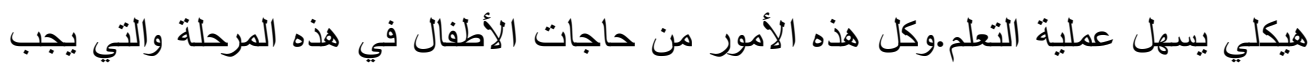




\section{المجلة العلمية لكلية رياض الاطفال - جامعة اسيوط}

إثباعها. لذا اعتمد البحث على استخدام بعض المفاهيم العلمية التي يتعامل معها طفل

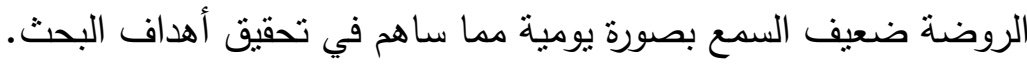

كما اتضح من نتائج البحث تميز أطفال المجموعة التجريبية والذين تتراوح أعمارهم

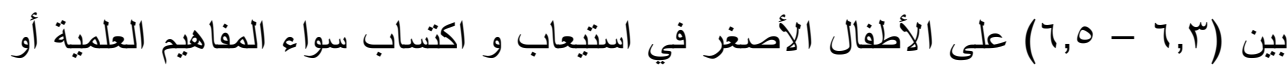

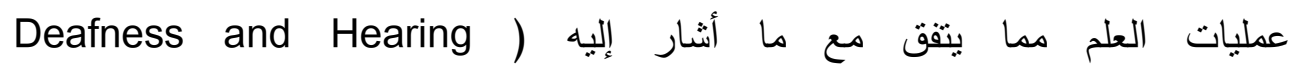
(Impairment,2006 والتي أثنارت إلى أن المعاقين سمعياً يكتسبون المفاهيم بنفس درجة التسلسل التقليدي لدى العاديين إلا أن اكتساب المعاقين سمعياً للمفاهيم المختلفة يتم فى إنى أعمار زمنية أكبر من العاديين، كما أنهم يعانون من صعوبات فى اكتساب المفاهيم

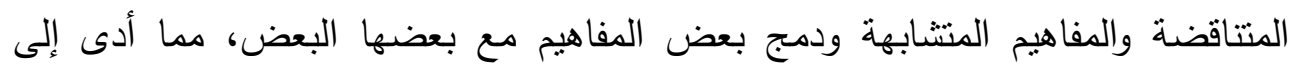

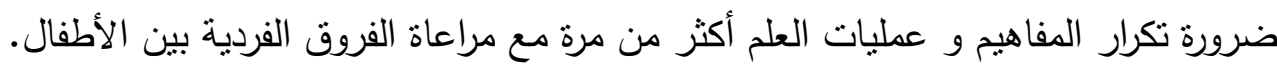
كما ساهم في تحقيق نتائج البحث ارتباط المفاهيم العلمية ببعض عمليات العلم مما ساهم في اكتساب طفل الروضة ضعيف السمع بالمجموعة التجريبية سواء للمفاهيم العلمية

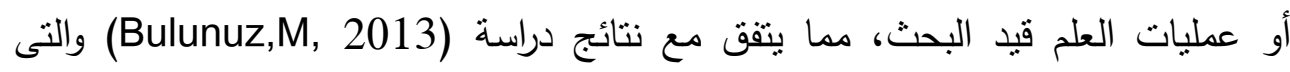
أوضحت أن امتزاج تقديم المفاهيم العلمية يساهم في اكتساب المهارات العلمية و العكس. وكما أثنار الباحثين والعلماء إلى أن طرق وأساليب التنريس التقليدية السائدة كما فى الإلقاء، والثرح، والعرض تؤثر فى تكوين المفاهيم العلمية وإستيعابها لدى المتعلمين، وكما تقول الحكمة: عندما لا يتعلم المتعلمين جيدا فى المدرسة، فإن ذللك يرجع فى فئ معظم الحالات إلى المعلم. حيث نؤثر طرق التدريس بصورة واضحة في تتمية المفاهيم العلمية

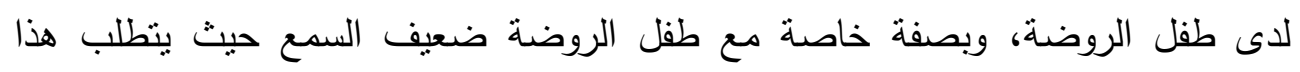

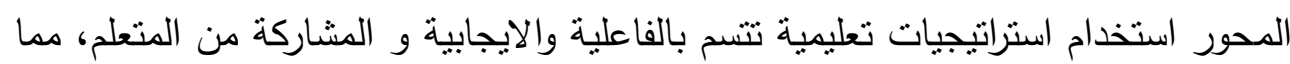

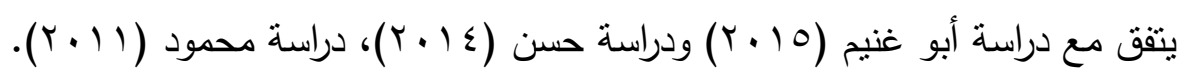

لذا ترجع الباحثة نتائج البحث إلى فاعلية برنامج الأنشطة التعليمية باستخدام

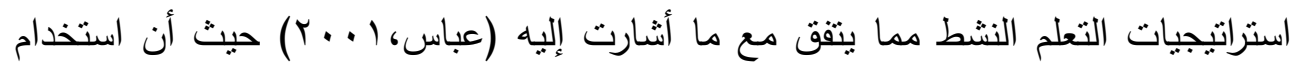
طرق واستراتيجيات تعليمية مناسبة يساهم في اكتساب المعاقين سمعياً للمفاهيم عامة. 
أ.م.د/ عبير صديق أمين

فاعلية برنامج قائم على استراتيجيات التعلم النشط في تنمية بعض المفاهيم العلمية وعمليات العلم الميجي لاى طقل الروضة ضعيف السمع لئح

وتخلص الباحثة مما سبق إلى تحقق صحة الفرض الثالث في وجود فروق دالة إحصائيا بين متوسطات رتب درجات أطفال المجموعة التجريبية و الضابطة في القياس البعدي على مقياس المفاهيم العلمية المصور و مقياس عمليات العلم لصالح المجموعة

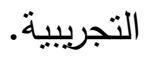

وتخلص الباحثة مما سبق إلى تحقى صحة فروض البحث كما يلي: - لاتوجد فروق ذات دلالة إحصائية بين متوسطات رتب درجات أطفال المجموعة

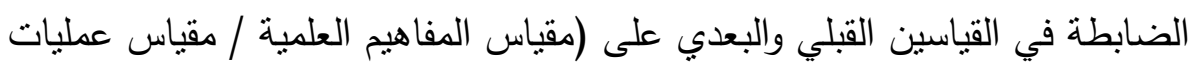
- العلم) - - توجد فروق ذات دلالة إحصائية بين متوسطات رتب درجات أطفال المجموعة

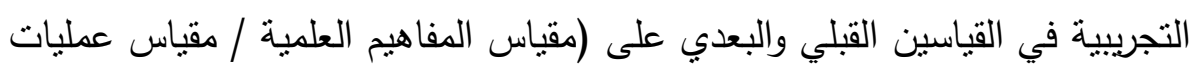

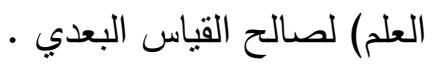
- توجد فروق ذات دلالة إحصائية بين متوسطات رتب درجات أطفال المجموعتين

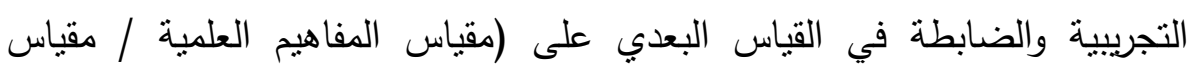
عمليات العلم) لصالح المجموعة التجريبية . تتائج البحث: من خلال البحث الحالي تحققت جميع فروض البحث وكانت نتائج البحث كالآتي:

عدم دلالة الفروق بين متوسطات رثب درجات أطفال المجموعة الضابطة في القياسين القبلي والبعدى على (مقياس المفاهيم العلمية / مقياس عمليات العلم). دلالة الفروق بين متوسطات رتب درجات أطفال المجموعة التجريبية في القياسين

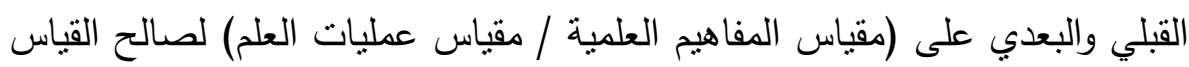
البعدي.

دلالة الفروق بين منوسطات رتب درجات أطفال المجموعتين التجريبية والضابطة في القياس البعدي على (مقياس المفاهيم العلمية / مقياس عمليات العلم) لصالح

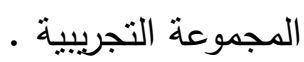


مما يوضح فاعلية برنامج أنشطة قائم على استراتيجيات التعلم النشط في تنمية بعض المفاهيم العلمية وعمليات العلم لاى طقل الروضة ضعيف السمع. توصيات البحث: في ضوء نتائج البحث توصي الباحثة بما يأتي: 1- نطوير المناهج الدراسية الخاصة بإعداد معلمي ذوي الاحتياجات الخاصة كلغة الإشارة الطوبر

r - تأسيس مراكز معلومـات لتسـهيل تبـادل الخبـرات والتجـارب العربيـة الناجحـة في مجالات التعليم والتأهيل والعمل والدمج وغيرها. r- التوسع في إنشاء وحدات للكثف المبكر عن الإعاقة في الريف والحضر وتزويدها بالمتخصصين المؤهلين القادرين على التدخل المبكر للحد من مضاعفات الإعاقة. ؟ - - التأكيد على اثتراك ذوب الاحتياجات الخاصـة في الأنشطة اللامنهجيـة والأنشطة الصيفية التي تتظمها المؤسسات التعليمية. هـ - مشـاركة الأثـخاص ذوبي الاحتباجـات الخاصـة وأسرهم في تخطبط وتتفيذ البرامج الخاصة لهم ومتابعة تتفيذها.

البحوث المقترحة: في ضوء نتائج البحث الحالي يمكن أن نقترح إجراء الأبحاث التالية:

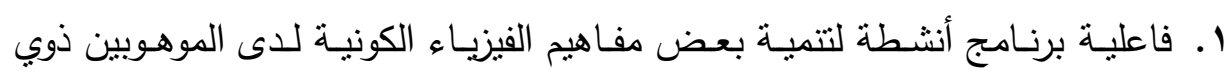
الاعاقة السمعية في رياض الأطفال.

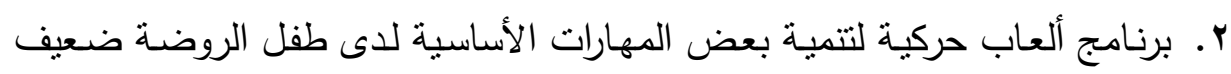
السمع.

r. برنامج أنشطة فنية لتنمية بعض المفاهيم البيئية لطفل الروضة ضعيف السمع.

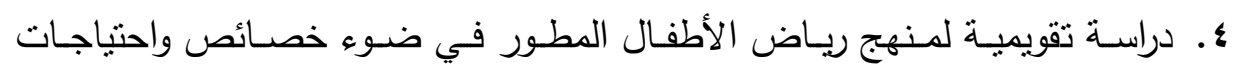
المعاقين سمعياً. هـ فاعلية برنـامج حاسوبي في تتميـة بعض المهارات اللغويـة لطفل الروضــة المعاق 


\section{مراجع}

$$
\text { أولاً : العراجع العربية: }
$$

- إبراهيم، السيد إبراهيم أحمد (T) (1): تأثير التلذل المبكر على تفضيلات المعينات السدعية لدى الأطفال ضعاف السدع • رسالة ماجستير ـ كلية التربية النوعية. جامعة بنها.

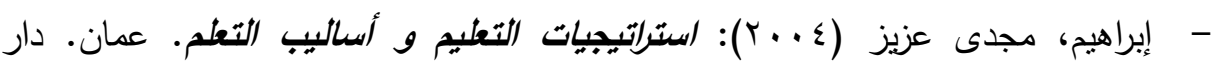
المسيرة للنشر والنتوزيع والطباعة. عزيز

Telecoil loop System أبو بكر، محمود حافظ محمد (T ا • ب) : بزنامج باستخد/م لذفض اضطرابات النطق و الكلام لدى عينة من الأطفال ضعاف السمع · ل رسالة

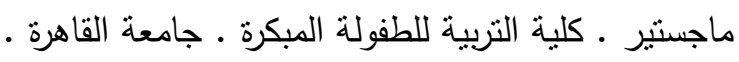
- أبو زينة ، فريد كامل وعباينة ، عبد الله.(· (ب). مناهج تلدييس الرياضيات للصفوف

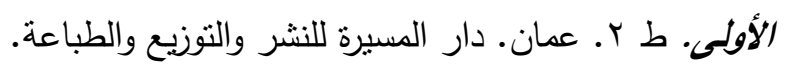

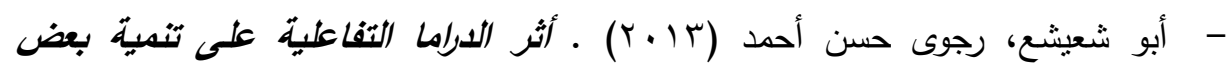

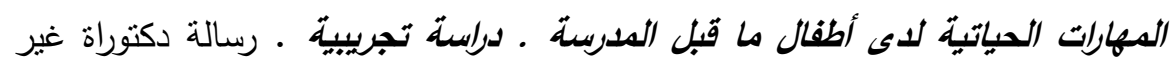

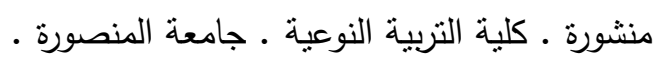

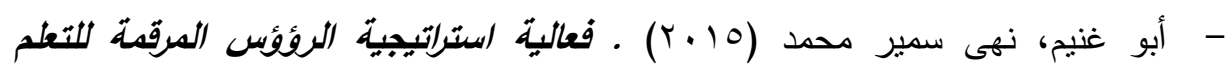

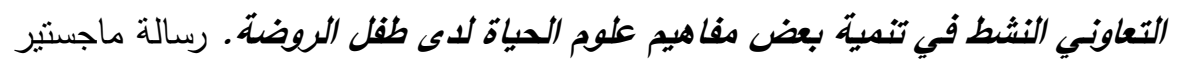

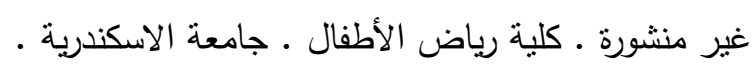

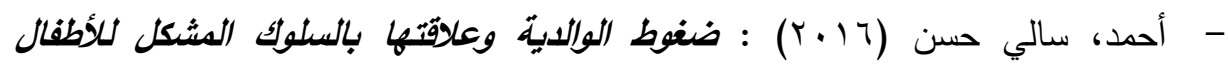
ضعاف السدع. رسالة ماجستير ـ كلية التربية للطفولة المبكرة .جامعة القاهرة.

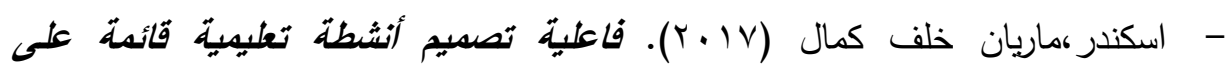
استراتيجيتي لعب الدور والاكتشاف لتنمية الذكاء الطبيعي لدى طفل الروضة.رسالة

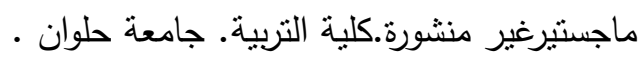




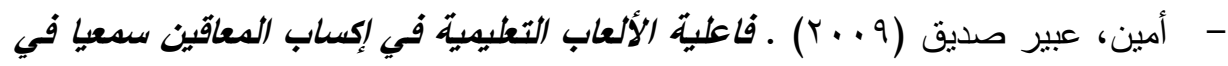

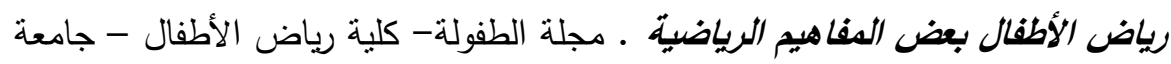
القاهرة • سبتمبر.

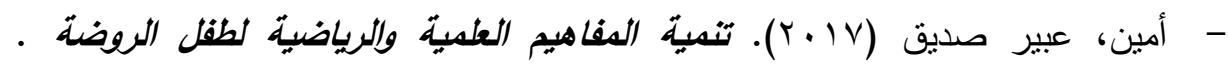

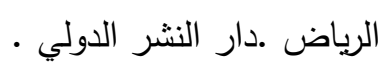

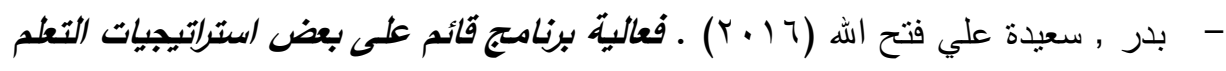

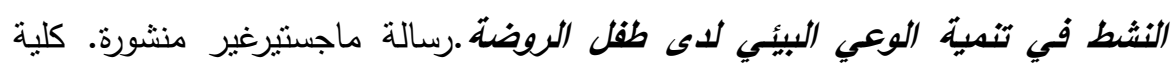

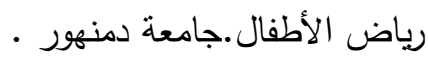

- تركستاني، مريم بنت حافظ عمر (T (Y) ـ أثنر الألعاب الالكترونية على مهارات حل

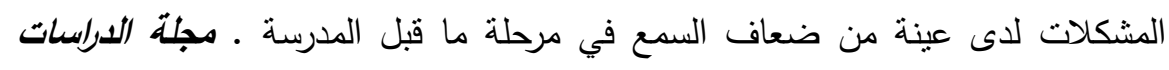

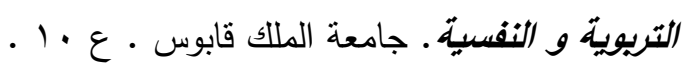

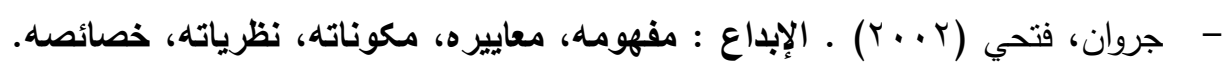

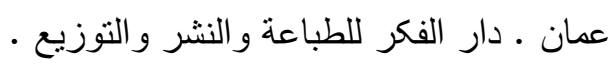
- - جعفر ، عطيات محمد سعد (Y.lV) · برنامج لاكساب طفل الروضة بعض مهارات الحوار قائم على التعلم النشط ـ رسالة ماجسنير غير منشورة ـ كلية التربية للطفولة

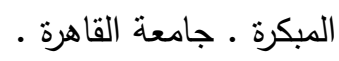

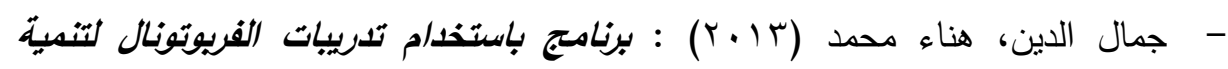

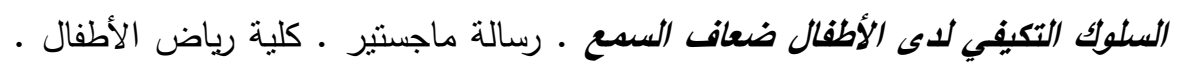

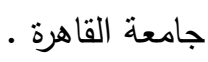

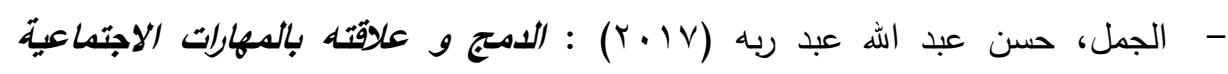
للأطفال ضعاف السدع المدمجين و غير المدمجين • رسالة ماجستير ـ كلية التربية للطفولة المبكرة ـ جامعة القاهرة .

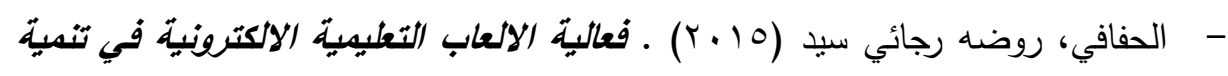

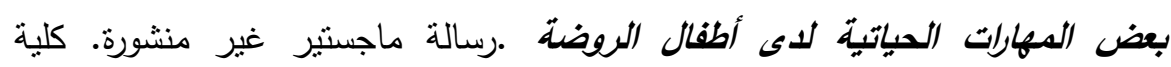

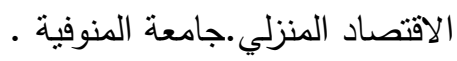


أ.م.د/ عبير صديق أمين

فاعلية برنامج قائم على استراتيجيات التطلم النشط

في تنمية بعض المفاهيم العلمية وعمليات العلم الميجي

لاى طقل الروضة ضعيف السمع العية

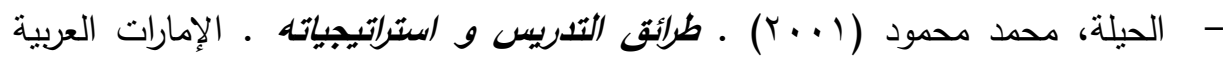

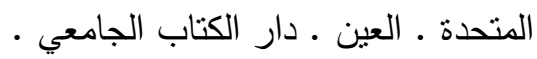

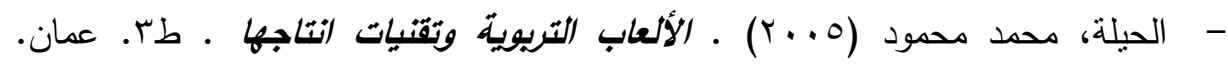

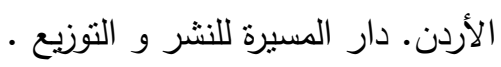

- حسن، حسن عمر (؟) (ب) . فاعلية برنامج قائم على استخدام الألعاب العلمية

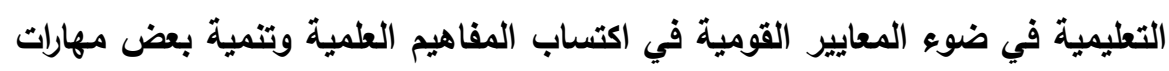

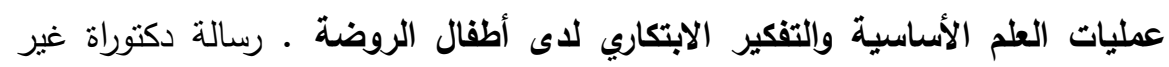
منشورة ـ كلية التربية ـ جامعة المنيا .

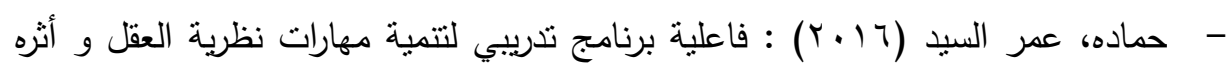

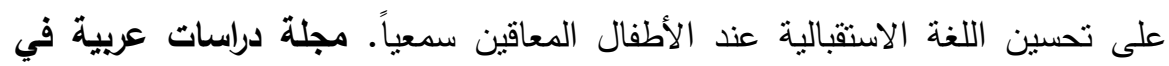

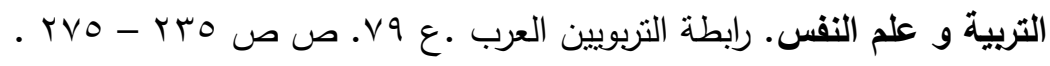

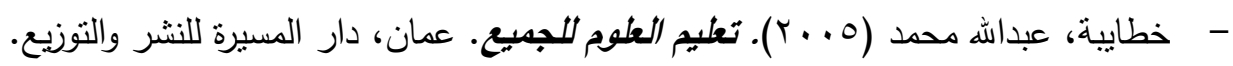

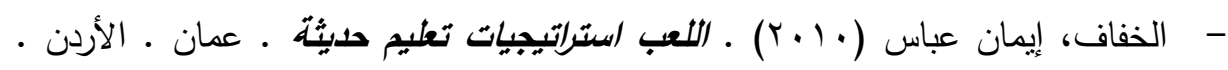
دار المناهج للنشر و التوزيع.

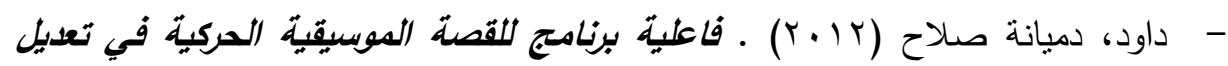
بعض سلوكيات الطفل المشكل في رياض الأطفال في ضوي استراتيجيات التعلم التعاونسي • رسالة دكتوراة غير منشورة ـ كلية رياض الأطفال ـ جامعة القاهرة.

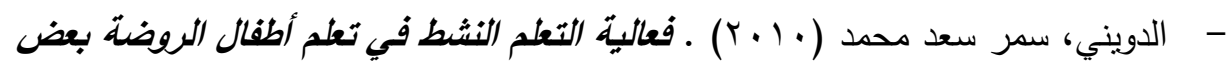

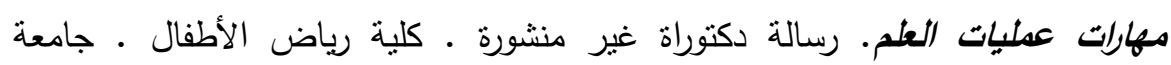

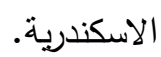

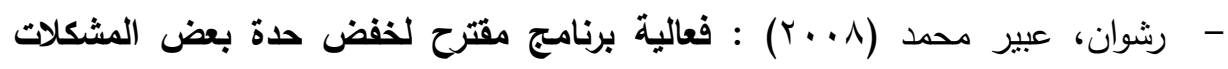
السلوكية لاى الأطفال ضعاف السمع في مرحلة رياض الأطفال.رسالة ماجستير . كلية

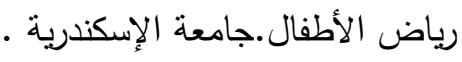

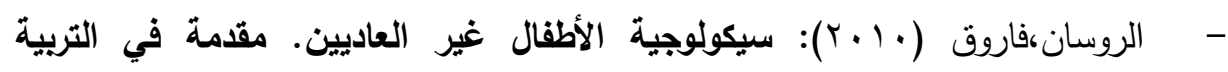

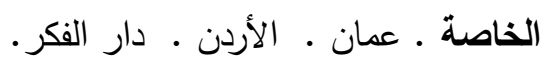




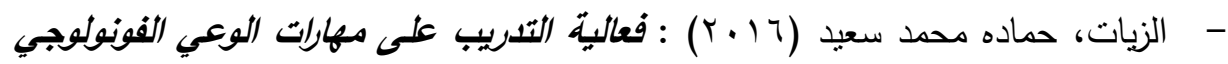

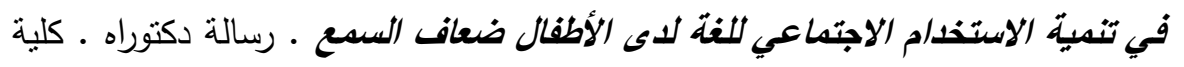

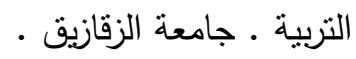

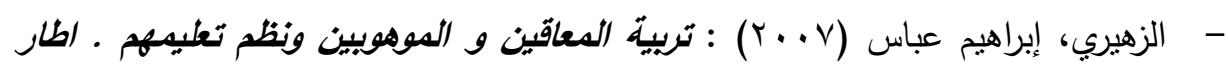

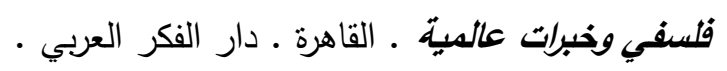

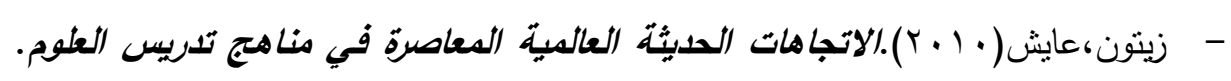
عمان • دار الثروق.

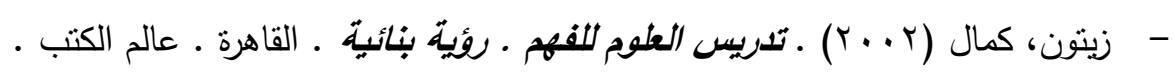

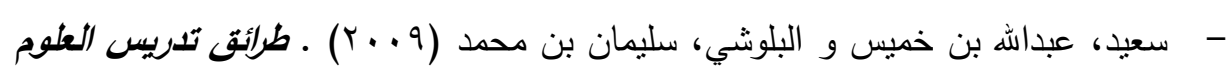

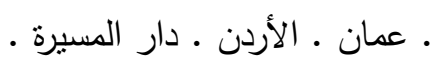

- سلامة، عادل (ء . ب) .تنمية المفاهيم والمهارات العلمية وطرق تدريسها. عمانالاردن. دار الفكر.

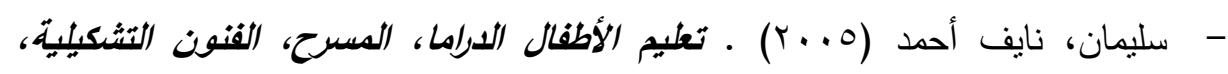
الموسيقا. دار صفاء للنشر والتوزيع. عمان.

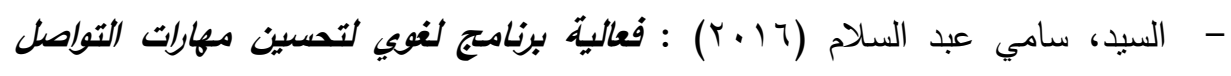

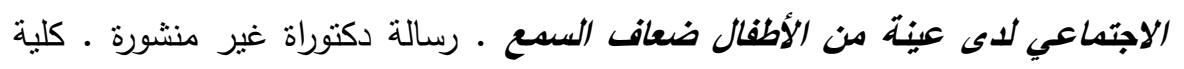

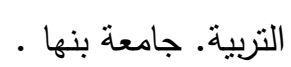

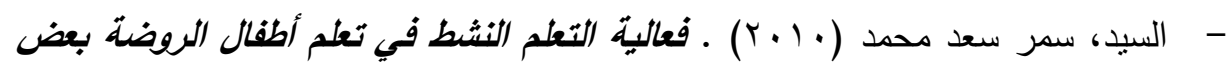

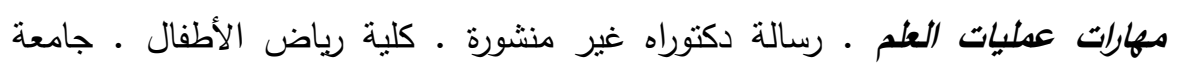
الاسكندرية .

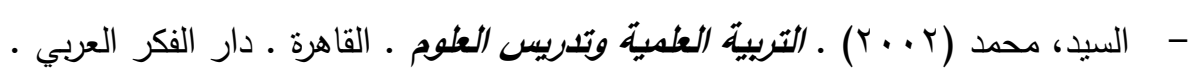

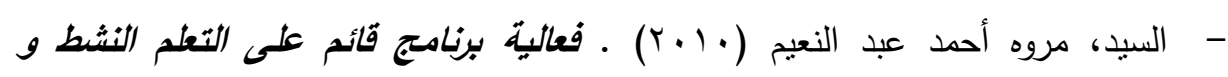

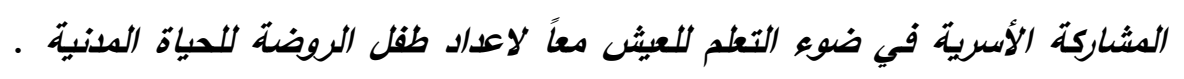

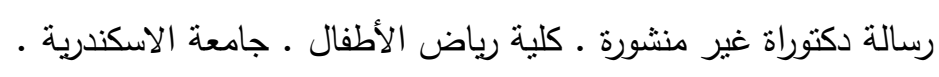




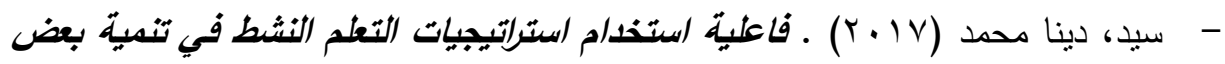
القدلات الابتكارية عند طفل الروضة ـ رسالة ماجستير ـ كلبة التربية للطفولة المبكرة .

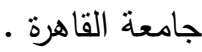

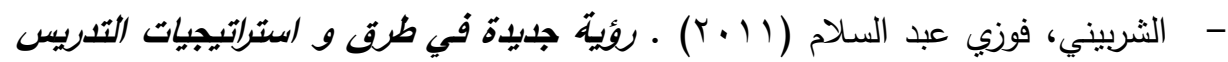

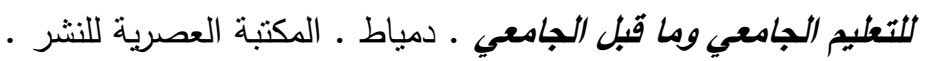

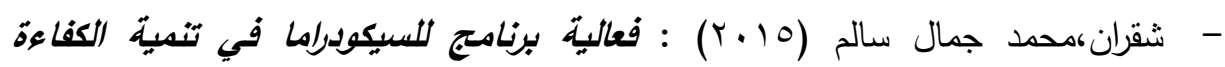
الاجتعاعية و علاقتها بذفض السلوك العدوانسي لدى الأطفال ضعاف السمع. رسالة ماجستير • كلية التربية.جامعة بنها.

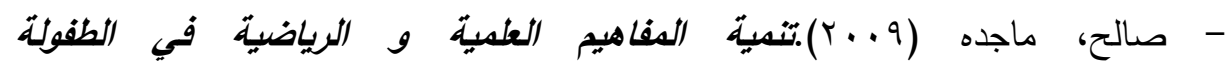

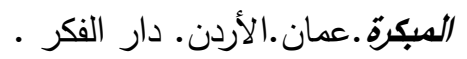

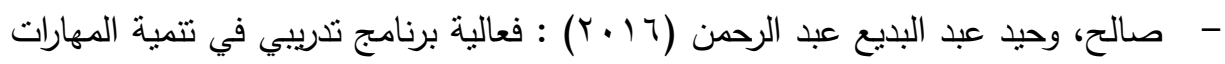
السمعية لتحسين اللغة الاستقبالية و التعبيرية لدى زارعي القوقعة ـ مجلة التربية الثاصنة

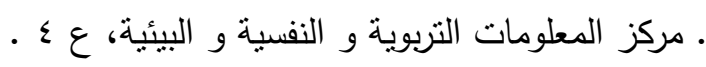

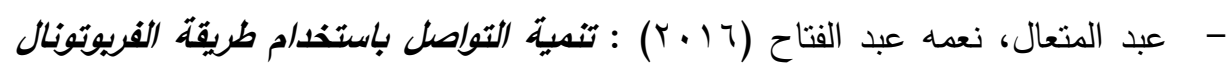

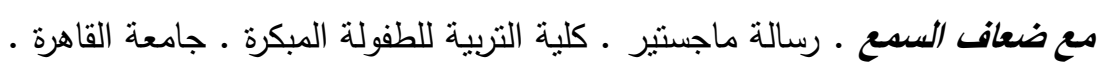

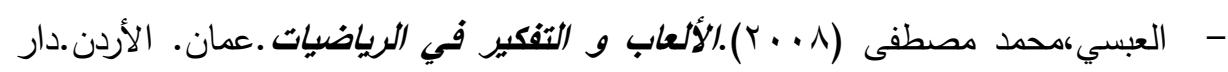

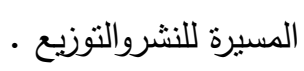

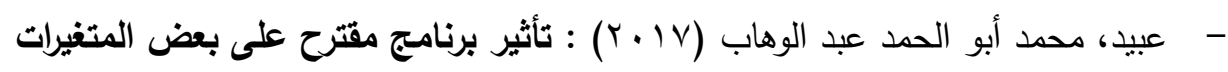
البذنية والمهارية والمعرفية على جهاز الحركات للأطفال ضعاف السمع ـ ـ رسالة دكتوراه

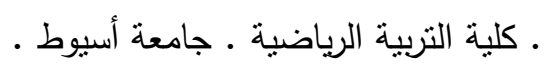

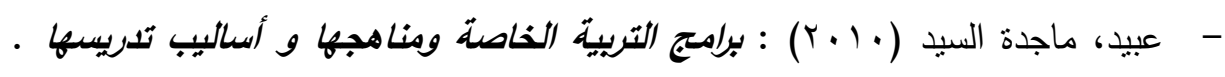

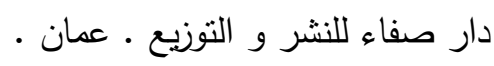

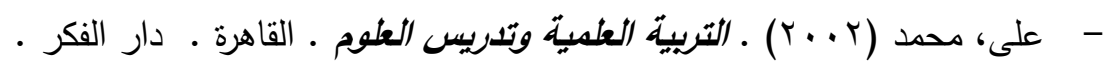

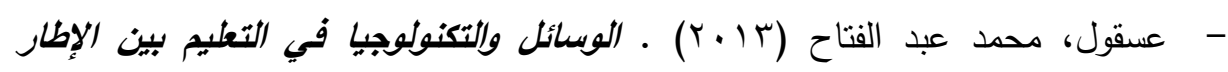
الفلسفي فالإطار التطبيقي • غزه ـ فلسطين ـ مكتبة آفاق . 


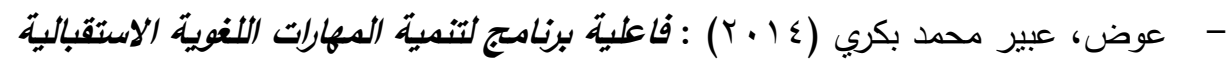
والتعبيرية لدى أطفال الروضة المعاقين سمعيًا . رسالة ماجستير ـ كلية رياض الأطفال

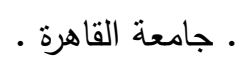

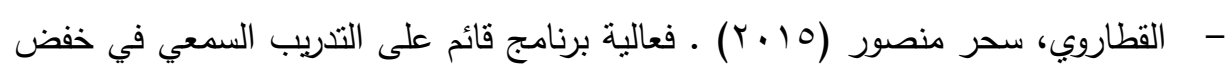

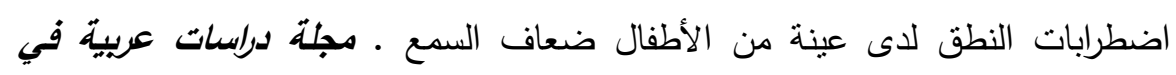

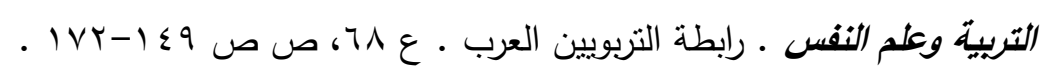
- كامل، هناء أحمد فتحي (10 ب ب) : تأثير المدخل المنظومي على تنمية بعض المهارات

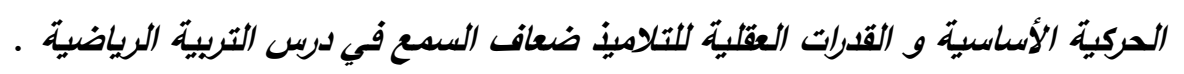
رسالة ماجستير . كلية التربية الرياضية ـ جامعة حلوان.

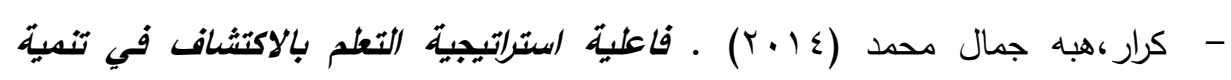

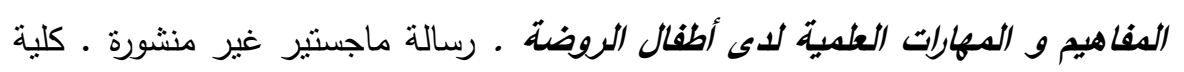

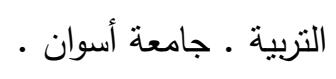

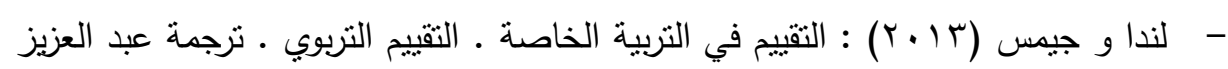
مصطفي السرطاوي و زيدان أحمد السرطاوى ـ عمان . ـ دار السيرة.

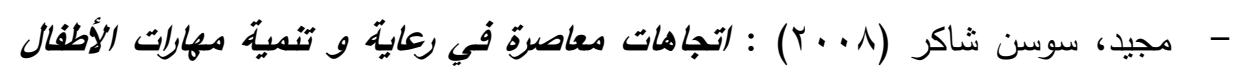

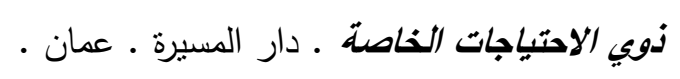

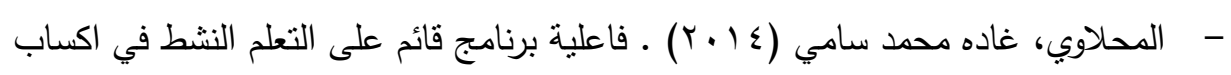

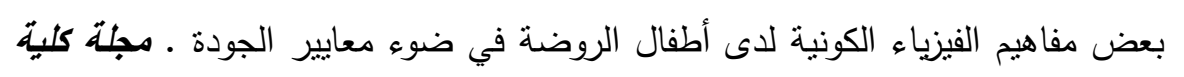

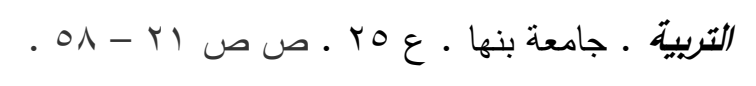

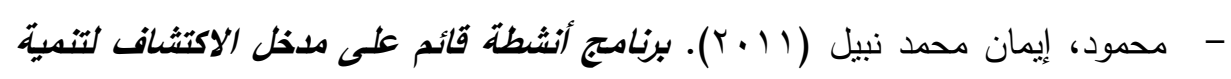

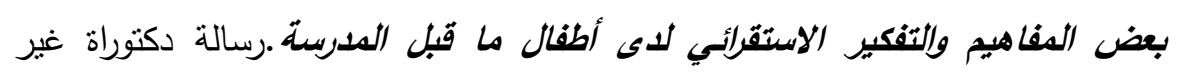

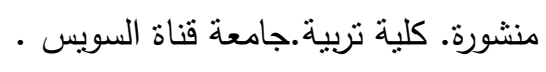

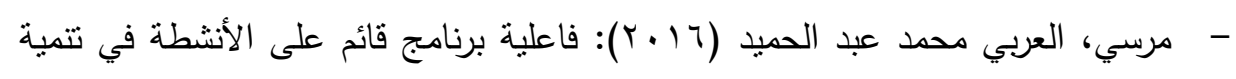

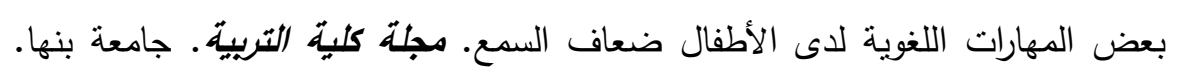
r r $r \varepsilon$ 


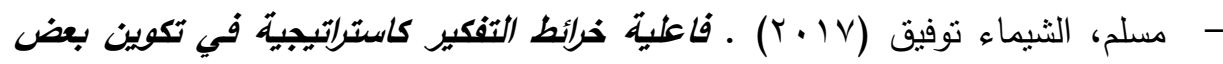

الدفاهيم البيولوجية لدى طفل الموضة ـ رسالة ماجستير غير منشورة ـ كلية البنات

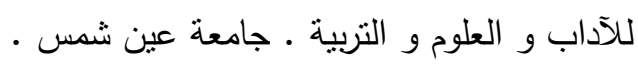

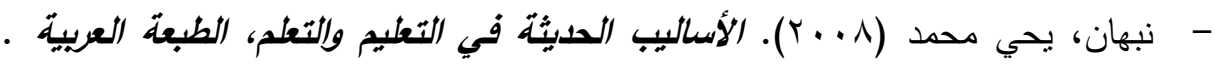

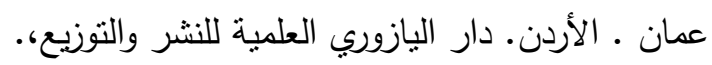

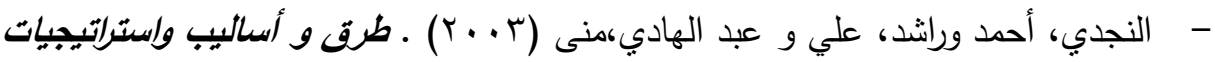

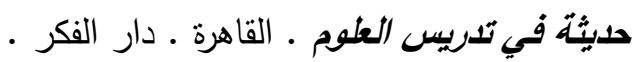

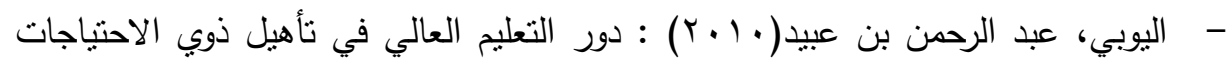

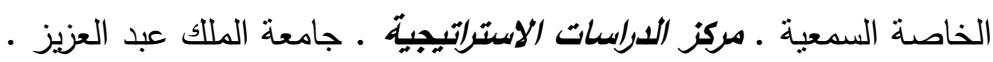

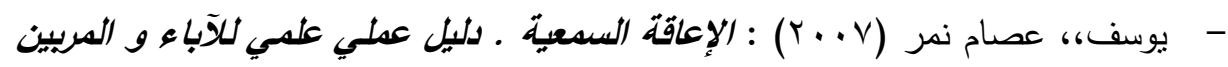

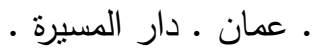

ثانياً :المراجع الأجنبية : n

- Abrahim, F. (2006) . Comparing Creative Thinking Abilities and Reasoning Ability of Deaf and Hearing Children, Roeper Review, Vol.28,Iss,3.

- Bulunuz,M,(2013). Designing Science Learning in the First Years of Schooling. An intervention study with sequenced learning material on the topic of 'floating and sinking . International Journal of Since Education. Volume 36. Issue 10 . PP 17511771. '

- Hannkainen, M ., Singer , E., Oers,B 0 (2013) Promoting play for a better future. European Early Childhood Education Research Journal. Volume 21, 2013 - Issue 2:pp 165 - 171

- Holm,C.S.(2001). Testing for Values the Deaf, The Language Cultural effects Journal of the Rehabilitation of the Deaf, Vol,18 . Iss,2.

- Jong , T ., Linn ,M ., Zacharia ,C.,(2013). Learning Science in the Schools 
- Research Reforming Practice • www.sciencemag.org • Vol 340 . pp 297-305.

- Marschark, M. (2003). Interactions of language and cognition in deaf learners: From research to practice International Journal of Audiology, (Supply.),

- McIntosh, R.A., Sulzen, L. , Reeder, K. and Hold, K. D.,(2005).Making science accessible to deaf students: The need for science literacy and conceptual teaching, American Annals of the Deaf,Vol. 139. Issue . 5: pp480-484.

- Ni Chang (2012). The Role of Drawing in Young Children's Construction of Science Concepts. Early ChildhoodEducation Journal ., Issue 3, pp 187-193.

- Ornit S., Levy ,Y \&Zemira M, (2013) . Science and Scientific Curiosity in Pre-school-The teacher's point of view. International Journal of Since Education . Volume 35. Issue 13 . pp2226- 2253.

- Shawn M. Glynn (2012) . Learning Science in the Schools Research Reforming Practice . ‘Reinders Duit

- WHO, Deafness and Hearing Impairment, World Health Organization,(2006) . Fact sheet; (March 2006) . 